$N / N D_{201} \quad$ no 435

M. Gerlagh

Introduction of Ophiobolus graminis into new polders and its decline 
M. Gerlagh

\section{Introduction of Ophiobolus graminis into new polders and its decline}

\section{PROEFSCHRIFT}

ter verkrijging van de graad van doctor

in de landbouwwetenschappen

op gezag van de Rector Magnificus, Dr. Ir. F. Hellinga, hoogleraar in de cultuurtechniek, te verdedigen tegen de bedenkingen van een commissie uit de Senaat van de Landbouwhogeschool te Wageningen op vrijdag 29 november 1968 te 16.00 uur

1968 Centre for Agricultural Publishing and Documentation Wageningen 


\section{STELLINGEN}

I

Bestrijding van planteziekten leidt tot agressiever pathogenen.

II

De processen die verlopen nadat schimmelsporen op de stempel zijn beland gelijken in hoge mate op hetgeen volgt op bestuiving met incompatibel stuifmeel.

cf. F. SCHÖNBECK, Untersuchungen über Blüteninfektionen. I. Allgemeine Untersuchungen zum Infektionsweg Narbe-Griffel Phytopath. Z. 59 (1967): 157-182.

III

De naar buiten gerichte groei van heksenkringen wordt voor een belangrijk deel veroorzaakt door ophoping van antagonisten van de betreffende zwam binnen de kring.

IV

Bij cacao induceert een maximum temperatuur boven $28,5^{\circ} \mathrm{C}$, resp. een verschil van meer dan $9^{\circ} \mathrm{C}$ tussen maximum en minimum temperatuur, 'flushing'. Het feit dat cacao ook tot 'flushing' komt bij een constante temperatuur lager dan $28,5^{\circ} \mathrm{C}$ is hiermee niet in strijd.

P. J. M. SALE, Effect of temperature on gTowth. In: A. Rep. Cacao Res. 1966 (1967): 33-38.

V

De potentiële produktie van moderne oliepalm-selecties wordt slechts bij een zeer ruim plantverband volledig benut.

L. D. Sparnaay, The oil palm. In: F. P. Fermerda (ed.), Outlines of perennial crop breeding in the tropics (ter perse).

VI

Bij verwante planten is de hoeveelheid genetisch materiaal (DNA) per cel positief gecorreleerd met de graad van zelfbestuiving.

H. ReEs \& G. H. JonEs, Chromosome evolution in Lolium. Heredity 22 (1967): 1-18.

VII

Bij de schatting van de 'heritability' worden gebalanceerde koppelingsgroepen van hoofdgenen niet onderkend.

B. T. O. Lee \& P. A. Parsons, Selection, prediction and response. Biol. Rev. 43 (1968): 139-174. 


\section{VIII}

Het 'Vertifolia-effect' bij de aardappel - achteruitgang in 'veldresistentie' tegen Phytophthora onder bescherming van fysio-specifieke R-genen - berust uiteindelijk op de specifieke genenbalans die ten grondslag ligt aan de veldresistentie.

J. E. van der Plank, Plant diseases: epidemics and control. 1963: 194-195.

\section{IX}

Verworven resistentie is een zeker even aannemelijke verklaring voor het optreden van groene eilanden in mozaïek-blad als bescherming door een deficiënte virus-stam.

J. P. Chalcroft \& R. E. F. Matthews, Role of virus strains and leaf ontogeny in the production of mosaic patterns by turnip yellow mosaic virus. Virology 33 (1967): 659-673.

$\mathrm{X}$

Het is onjuist bij virussen van de 'squash mosaic' groep' te spreken over activering van de infectiositeit. Beide componenten zijn op zichzelf niet infectieus.

J. B. BANCrofT, Plant viruses; defectiveness and dependence. Symp. Soc. gen. Microbiol. 18 (1968): 229-247.

A. VAN Kammen, The relationship between the components of cowpea mosaic virus.

I. Two ribonucleoprotein particles necessary for the infectivity of CPMV. Virology 34 (1968): 312-318.

$\mathrm{XI}$

'Gezond eigenbelang' - alom geprezen motief voor ontwikkelingshulp - kan geen uitgangspunt zijn voor het verkrijgen van, naar evangelische maatstaf, gezonde verhoudingen.

cf. Uw dagblad.

XII

Het gebruik van academische titels anders dan ter aanduiding van bijzondere deskundigheid op een gebied waarover men zich uitlaat, is een symptoom van het slecht functioneren van de democratie.

Proefschrift van M. GerLaGH

Wageningen, 29 november 1968 


\section{Voorwoord}

Wie het voorrecht heeft een uitgestippelde weg vrijwel ongestoord te kunnen volgen, vergeet maar al te vaak dat dit 'meer geluk dan wijsheid' is. Een promotie verschaft echter een goede gelegenheid om uitdrukking te geven aan gevoelens van dankbaarheid.

Het arbeidsklimaat is van niet te overschatten belang. Dat het onderzoek, waarvan het resultaat thans voor $U$ ligt, steeds met vreugde kon worden verricht, is te danken aan de uitstekende sfeer, die op het Laboratorium voor Fytopathologie heerst. U, Hooggeleerde Oort, moogt $U$ voor een groot deel daarvoor verantwoordelijk weten. De vrijheid die $U$ ieder laat om te werken naar eigen inzicht en belangstelling ligt ten grondslag aan de hier afgedrukte resultaten. Daarbij heb ik steeds weer aan Uw grote belangstelling voor dit onderzoek en Uw goede suggesties kunnen konstateren dat oude liefde niet roest. In de bekende lasten van het schrijven van een dissertatie hebt $U$ ruimschoots gedeeld. Ik ben $U$ daarvoor zeer dankbaar.

Beste Annie (van Gelder)! Jij hebt niet de vrijheid van werken mogen genieten waarvan ik zojuist met waardering sprak. In tegendeel, vaak moest ik je wel vragen werkzaamheden te verrichten waarvan de ervaring leert dat zij het enthousiasme temperen. Hoewel het jou aan ervaring bepaald niet ontbrak, leed je er, zo te zien, niet onder. Hopelijk heb je van je hart geen moordkuil gemaakt; dat ligt trouwens niet in jouw lijn. Met vreugde en dankbaarheid memoreer ik jouw aandeel in dit werk.

Beste Gerrit (Bollen)! Veel hebben we samen besproken. Daarbij ging het niet alleen, en zelfs niet in de eerste plaats, over het werk. Jouw bereidheid steeds iedereen te helpen, ook al vertraagt dat vaak je eigen werk, vindt ook in dit proefschrift zijn weerspiegeling, zij het voor de meesten onzichtbaar. Vaak zijn kritische geesten niet loyaal en loyale geesten niet kritisch. Jij hebt me echter getoond dat kritisch en loyaal zeer goed kunnen samengaan. Ik hoop er iets van geleerd te hebben.

Beste 'lab-genoten'! Ik zou allen tekort doen als ik $U$ hier allen zou opsommen: $U$ vormt geen saaie reeks. Allen draagt $U$ bij tot de goede sfeer op het laboratorium. Ik ben blij enige jaren in Uw midden te hebben verkeerd. Daarbij moet ik toegeven dat ik vermoedelijk meer aan $U$ gehad heb dan $U$ aan mij.

Vader en moeder, $U$ hebt $U$ veel moeiten en kosten getroost om Uw kinderen dat te geven, waarop $U$ vond dat ze recht hadden. Dit gebeurde grotendeels in een tijd toen, anders dan nu, de maatschappelijke omstandigheden moeilijk waren. Bij deze laatste stap van de opleiding beken ik $U$ graag mijn vaak onuitgesproken dankbaarheid voor het vele goede bij $U$, in het gezin, ervaren. De door $U$ begonnen opvoeding wordt thans door $\mathrm{Yt}$ en twee dochters voortgezet. 
Yt! Gewoonlijk wordt op deze plaats de vrouw bedankt voor wat ze zich heeft ontzegd voor het werk van haar man. Jij neemt het mij niet kwalijk als ik dàt niet doe. Beiden weten we dat we slechts dankbaar kunnen zijn voor de zeer gunstige omstandigheden waaronder wij leven. Toch heb je wel eens tegen een somber gezicht moeten aankijken. Maar of je daaraan ná deze promotie zult ontkomen. ..? 


\section{Contents}

1 INTRODUCTION 1

2 TAKE-ALL DISEASE CAUSED BY OPHIOBOLUS GRAMINIS 3

2.1 The hosts 3

2.2 Description of the disease 3

2.3 Life cycle of the causal fungus 4

2.4 The effect of crop rotation 5

3 MATERIALS AND METHODS AS GENERALLY USED IN LABORATORY EXPERIMENTS 6

3.1 Ophiobolus inoculum $\quad 6$

3.2 Growing the crop $\quad \cdot \quad 7$

3.3 The greenhouse $\quad 8$

$\begin{array}{lll}3.4 & \text { Soil } & 8 \\ 3.5 & \text { Disease assessment } & 8\end{array}$

4 INTRODUCTION OF OPHOBOLUS INTO THE NEW POLDERS 11

4.1 Occurrence in different parts of East Flevoland

4.1.1 Ophiobolus on grasses $\quad 12$

4.1.2 Ophiobolus in first wheat crops 12

4.1.3 Discussion 16

4.2 Occurrence on Eemeiland 17

4.3 Infection experiments with wheat and grasses growing in subsoil clay 20

4.3.1 Experiments in the greenhouse $\quad 20$

4.3.2 Infection of wheat in subsoil clay in the open air : : $\quad 23$

4.4 Discussion and conclusions on the spread of Ophiobolus 23

5 : 'DecLine' of OPHIOBOLUS $\quad \therefore \quad \cdots \quad 27$

5.1 The decline phenomenon $\quad 27$

5.2 Demonstration of decline 28

5.2.1 Observations on decline in the North-East Polder $\ldots$

5.2.2 Demonstration of decline in East Flevoland : : : : : : : $\quad 28$

5.2.3 Reproduction of decline in the greenhouse

5.2.4 Discussion: general and specific antagonism $\quad 33$

5.3 Specificity of Ophiobolus in inducing decline $\quad \ldots \quad \ldots \quad \ldots$

5.3.1 Does an avirulent strain of Ophiobolus induce antagonism? 38 
5.3.2 Do other fungi induce antagonism to Ophiobolus?

5.3.3 Discussion 40

5.4 Eliminating decline with other crops than wheat and barley $\quad 40$

5.4.1 The effect of interruption of LO treatment or continuous cereal growing on decline of Ophiobolus

5.4.2 Effect of the type of previous crop on severity of disease in wheat inoculated with Ophiobolus

\subsubsection{Discussion}

6 INDIRECT METHODS TO ESTABLISH THE MICROBIAL ORIGIN OF DECLINE

6.1 Sterilization and partial sterilization of antagonistic soil by chemicals or. heat

6.1.1 Materials and methods

6.1.2 Results and discussion $\quad: \quad \because \quad 47$

6.2 Dilution of antagonistic soil with fresh soil 51

6.2.1 Materials and methods 51

6.2.2 Results $\quad 51$

6.2.3 Discussion $\quad 53$

6.3 The antagonistic activity of soil extracts $\quad 55$

$\begin{array}{ll}\text { 6.3.1 Materials and methods } & 55\end{array}$

6.3.2 Results and discussion $\quad 56$

6.4 Discussion $\quad 58$

7 SEARCH FOR THE ORGANISM(S) ANTAGONIZING OPHIOBOLUS $\quad 60$

7.1 Number and antagonistic activity of micro-organisms isolated from soil 60

7.2 Fungi emerging from straws buried in soil 61

7.2.1 Materials and methods 61

7.2.2 Results 64

7.2.3 Discussion 65

7.3 Infection of wheat with Ophiobolus inoculum to which other fungi have been added 66

7.3.1 Materials and methods $\quad 66$

$\begin{array}{lll}\text { 7.3.2 Results } & 67\end{array}$

$\begin{array}{ll}\text { 7.3.3 Discussion } & 67\end{array}$

7.4 Some remarks on soil ecology and the determination of the antagonistic microflora $\quad 69$

8 FURTHER ANALYSIS OF DECLINE 71

8.1 Determination of the antagonism to Ophiobolus under artificial conditions

8.1.1 Materials and methods $\quad \because \quad \quad 72$

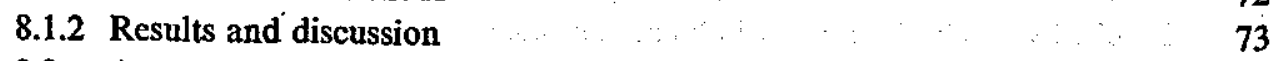

8.2 Assessment of the antagonism with methods imitating natural conditions 76 
8.2.1 Antagonism to Ophiobolus during its saprophytic phase

8.2.2 Antagonism to Ophiobolus in its parasitic phase

8.2.3 The effect of temperature upon the antagonism to Ophiobolus 79

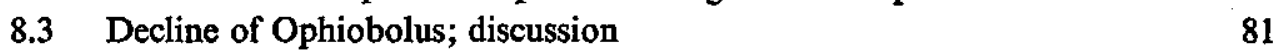

$\begin{array}{ll}\text { SUMMARY } & 82\end{array}$

$\begin{array}{lll}\text { SAMENVATtING } & \cdot & 84\end{array}$

$\begin{array}{ll}\text { ACKNOWLEDGMENTS } & 87\end{array}$

$\begin{array}{lc}\text { REFERENCES } & 88\end{array}$ 


\section{Introduction}

Root and foot rots are among the most harmful diseases in cereal growing. The take-all disease, caused by Ophiobolus graminis Sacc. (hereafter indicated as $O p h$ iobolus only), is one of the most serious of these root diseases. Though occurring all over the Netherlands, the ill repute of the disease in this country is connected with its occurrence in the newly drained polders.

In 1930 the Wieringermeer Polder was drained. The salinity of the soil has been one of the problems in this polder. After the construction of the Impounding Dike in 1932 the water of the Ysselmeer gradually decreased in salinity. Therefore salt has not been an important factor in the reclamation of the North-East Polder and East Flevoland, which have been drained in 1942 and 1957, respectively. Yet the condition of the soil during the first years is such that only few crops can be grown profitably. These are mainly cereals and rape. They also fill the need for labour-saving crops, since their cultivation can be completely mechanized. In the Wieringermeer Polder two successive crops of cereals were frequently grown during the first years. Ophiobolus proved to heavily attack a second susceptible crop (wheat or barley) (ANONYMUs, 1955). Heavy losses due to Ophiobolus when susceptible cereals are grown in succession were also found during the first years of the North-East Polder (BosMA, 1946) and East Flevoland (JONKER, personal communication).

In the Wieringermeer Polder difficulties in the mechanical harvesting of rape caused cereals to be grown during the first two years whenever possible. The heavy losses from Ophiobolus came as a surprise. In the North-East Polder and East Flevoland the crop rotation had to be changed to prevent damage by Ophiobolus. A survey of land-use in East Flevoland during the first years, based on a mass of experience from the Wieringermeer and the North-East Polder, is as follows.

Reed (Phragmites communis L.) is sown after draining. This has a double function: it completely covers the soil about two years after sowing, thus removing weeds already established and preventing the establishment of others; secondly it helps to dry the soil and improve its structure. The polder is reclaimed by removing the reed, draining and ploughing. The soil is divided into fields of 300 metres by 1000 metres surrounded by ditches. Each year about 4000 ha are reclaimed, working from East to West. Winter rape is nearly always sown as a first crop. Second crop is winter wheat and third barley, which is more tolerant of take-all than wheat, or flax. After that any crop can be grown. The first four or five years the land is cultivated by the Rijksdienst voor de IJsselmeerpolders (Ysselmeer Polders Development and Settlement Authority). Since the Authority has about 20,000 ha under cultivation 
labour-saving crops must be grown. The time of harvesting should be spread as much as possible. Fortunately rape, barley and wheat, the crops which grow very well during the first years, suit that need. During the fourth year of culture crops like beet and potatoes, which then grow very well, are excluded for technical reasons. After four or five years culture private farmers lease the land.

Though Ophiobolus is checked by the crop rotation, its behaviour in the polders is still worth consideration, since an increase in the share of cereals is now economically profitable. The following questions should be especially considered:

1. introduction and spread in the polder;

2. the severe damage to a second susceptible cereal crop;

3. the decrease in Ophiobolus attack with the continuous growing of susceptible cereals; this has been observed regularly on trial fields in the North-East Polder and East Flevoland.

Since the paramount importance of microbial antagonism ${ }^{1}$ to Ophiobolus is well known, the phenomenon put forward in the second question can presumably be ascribed to lack of activity of other micro-organisms during the initial years of cultivation. This can explain the big damage by Ophiobolus (BosMA, 1962). It will not be discussed here. The introduction of Ophiobolus is a more difficult problem; in chapter 4 observations and experiments relating to it will be described. The decrease in Ophiobolus attack with continuous wheat or barley growing (decline) will be treated in chapters 5 to 8. Preceding the experimental part of this paper a brief description of the disease induced by $O$ phiobolus is given in chapter 2, whereas chapter 3 discusses materials and methods.

1 In this paper antagonism is always used in its broadest sense, including antibiosis, competition
and hyperparasitism. 


\section{Take-all disease caused by Ophiobolus graminis}

\subsection{The hosts}

Ophiobolus is a root parasite and attacks many cereals and other Gramineae; it occurs all over the world. Wheat and barley are highly susceptible and yields of these crops, especially wheat, may be severely reduced. Rye and maize can also be attacked (RoBINSON \& LUCAS, 1967), whereas oats is only susceptible to a special strain of Ophiobolus (TURNER, 1940), which seems infrequent.

In the literature many grasses are reported to be carriers of Ophiobolus (BANYER, 1966; BRooKs, 1965b; GARRETT, 1941; GoTTLIEB, 1957-8; KIRBY, 1922; VAN DE LAAR, 1931; Padwick, 1935; du Plessis \& NortJÉ, 1952; Robinson \& LuCas, 1963). These grasses may be important in the epidemiology of Ophiobolus in arable land, although this view is partly disputed by others (ZoGG, 1963). More information about grasses as carriers can be found in BuTLER's excellent review (1961).

Some of the grasses commonly found in the Ysselmeer Polders are Catabrosa aquatica P.B., Dactylis glomerata L., Festuca pratensis Huds., Lolium perenne L., Poa annua L., and Puccinellia distans Parl. Their capacity to carry Ophiobolus, already known from the literature for most of them, was confirmed during this study. Also reed (Phragmites communis L.), which covers the larger part of the polders for many years before reclamation, proved to be a carrier of Ophiobolus.

\subsection{Description of the disease}

Wheat is the most important crop attacked by Ophiobolus. Therefore the disease will be described on wheat.

The fungus infects roots, partly growing superficially with dark-brown so called runner hyphae. As infection proceeds, the roots rot and turn brownish to black, and the plants become stunted and desiccated. At this stage the fungus also establishes itself at the stem-base where it forms a black mat below the leaf sheaths. In this mat perithecia may form; they protrude through the leaf sheaths.

The disease may cause plants to die at any stage of development. But, in the field root deterioration usually is not fatal until a few weeks before healthy plants reach maturity. At this stage diseased plants die quickly; the leaves die and roll up from the base upwards and at last also the ear dies and becomes yellowish white. The name 'whiteheads' is used to indicate this symptom. Whiteheads, however, may have many other causes. The 'take-all' symptom, death of wheat plants at an early stage of 
development, may occur in the field but is easily overlooked. In greenhouse experiments it is common, however, due to infection of young plants with a high dose of inoculum. Within a few weeks many plants may die. The surviving ones later seem to recover, but remain distinguishable from healthy plants by their retarded growth; after flowering they show the whitehead symptom. All this results in an uneven stand.

The symptoms on the shoot are correlated with the development of the root system. The first weeks after sowing, the plant depends on its seedling roots for water supply. Attack by Ophiobolus at this stage may be disastrous. After that, there is a rapid increase in root mass during the growth stages 5 to 8 (Feekes scale; LARGE, 1954). The maximum root mass is reached at growth stages 10.1-10.5. After that root mass decreases (JONKER, 1958), so that whiteheads appear rapidly since no new roots can replace the roots destroyed by Ophiobolus.

\subsection{Life cycle of the causal fungus}

During the growing season Ophiobolus thrives on and in the roots of its hosts. It can continue to parasitize perennial grasses the year round. When a cereal crop is ripe the fungus can survive saprophytically on dead roots and stubble which it has previously parasitized. According to GARRETT (1956) the fungus has a low "competitive saprophytic ability", so it cannot colonize fresh organic material while the stubble and roots are decomposing. But WINTER (1947, 1950-1) says that $O$ phiobolus might have a higher saprophytic ability than is generally assumed. Yet certainly survival of Ophiobolus in arable land depends on the growing of susceptible crops at least once in two years or on the presence of grass weeds.

Besides its hyphal structures Ophiobolus produces perithecia, with ascospores, and microconidia of uncertain function. Perhaps microconidia play a role in fertilization, since they are always found in combination with perithecia (GINDRAT, 1966). At any rate, it is generally assumed that they do not cause infection of plants. The air-borne ascospores are forcibly ejected when the perithecia are wetted by rain. SAMUEL \& GARRETT (1933) believed they were responsible for the spread of Ophiobolus to newly reclaimed land in Australia. Later GARRETT (1939) showed that they are only infectious under completely sterile conditions, so that air-borne spread of the disease seems doubtful.

BRooxs (1964, 1965a), however, proved ascospores to be infectious on exposed roots of wheat seedlings germinating on the soil surface. Whether this fact will help to explain the spread of Ophiobolus in practice remains doubtful, since GREGORY \& HENDEN (1967) failed to infect wheat plants by growing seedlings with exposed roots in a box placed in a field with wheat stubble bearing sporulating perithecia.

The facts mentioned support the view that antagonism of other soil micro-organisms is important in the survival and spread of Ophiobolus. During the saprophytic phase, when Ophiobolus is assumed to be more sensitive to antagonism than in the parasitic phase (GrossmanN, 1954; SCHMIDT, 1962), the mycelium only survives on material 
which has been already infected. Apparently the ascospores have very few opportunities of establishing infection unless antagonism is eliminated.

\subsection{The effect of crop rotation}

During growth of a susceptible crop the inoculum of Ophiobolus in the soil increases sharply. After harvest the mycelium of Ophiobolus on stubble and remains of roots dies and decomposes within about a year, depending on the activity of antagonistic micro-organisms ${ }^{2}$. Therefore, big losses from Ophiobolus can generally be prevented by growing a susceptible crop not more than once in two years. Since grasses may carry Ophiobolus the break-crop should be kept free from grasses. This will never be completely successful, especially at the borders of the field, so that grass weeds can be held responsible for the maintenance of Ophiobolus in a 'healthy' crop rotation. The effect of grassland as an interruption of cereal growing is disputed. This will be discussed in more detail later (5.4.3).

Growing two or more cereal crops in succession will cause the build-up of a high inoculum level, leading to serious losses in the second or third crop. The fate of Ophiobolus with continuous cereal growing will be dealt with in chapter 5 .

2 This looks favourable when compared with the three years needed to eliminate eyespot (Cercosporella herpotrichoides Fron). 


\section{Materials and methods as generally used in laboratory experiments}

Materials and methods used in field trials or in experiments of a special design are described in the pertinent paragraphs.

\subsection{Ophiobolus inoculum}

A highly virulent single-spore isolate of Ophiobolus was used. It was kept and multiplied on PDA (potato dextrose agar) slants. Ophiobolus looses its virulence after prolonged culture on this medium, so a fresh virulent isolate was obtained about thrice yearly from perithecia-bearing wheat stubble kept in the refrigerator at $4^{\circ} \mathrm{C}$. This stubble originated from wheat grown in the field and inoculated with the original strain of Ophiobolus. At $4^{\circ} \mathrm{C}$ the ascospores remained viable for more than one year, so that the supply of virulent $O$ phiobolus was ensured by collecting stubble of artificially inoculated wheat once a year.

The medium used for soil infestation with Ophiobolus consists of:

wheat grains

( $80 \%$; dry weight)

chopped wheat straw $(20 \%$; dry weight $)$

water

The medium is prepared by cooking the straw with excess water for about 10 minutes. Then the straw is strained to remove surplus water. The straw imbibes and holds about 5 times its dry weight of water. Mixing the wet straw with the dry grains results in a suitable moisture content. The medium is put into wide-mouthed 1-litre Erlenmeyer flasks, which are twice autoclaved at $120^{\circ} \mathrm{C}$ for one hour at an interval of 24 hours. The flasks are inoculated with about $75 \mathrm{ml}$ of a shake culture of Ophiobolus on potato dextrose broth. After $21 / 2-4$ weeks of incubation at room temperature the inoculum is ready for use. Inoculum, $1 \%$ by fresh weight, is added to the soil and mixed thoroughly with the top $7-10 \mathrm{~cm}$. Since the amount of organic material added is not very high and since the C:N ratio (about 25 ) favours fermentation, the disturbance of the microbial equilibrium of the soil is assumed to remain within reasonable limits. The treatment is indicated as LO (living Ophiobolus). As a check, a treatment is included with Ophiobolus prepared in the same way as described for LO but killed by application of chloropicrin two days before mixing with the soil. This treatment is called DO (dead Ophiobolus). A treatment without any additive to the soil (NO) serves as a second check. 


\subsection{Growing the crop}

All trials were with one variety, namely Peko spring wheat. For some 6-litre Mitscherlich pots were used, each containing about $5 \mathrm{~kg}$ soil. For others wooden boxes $23 \mathrm{~cm} \times 23 \mathrm{~cm} \times 13 \mathrm{~cm}$ each with about $6 \mathrm{~kg}$ soil were used. The pots were weighed three times a week to keep the soil moisture at $50 \%$ of the field capacity. Since the weight of the growing plants was not taken into consideration soil moisture decreased slightly when the plants grew older. In the wooden boxes moisture status was not controlled. They were watered according to apparent need. In the pots 15 seeds were sown, in the wooden boxes 25 . Shortly after germination the number of plants in the pots was reduced to 10. In a few experiments clay pots were used; if so the number of seeds was adapted to the size of the pots. The soil was kept free from weeds and the surface layer was loosened whenever necessary.

The greenhouse trials lasted about 3 months. After this period the plants had reached about the flowering and after-flowering stages (10.5.1 to 10.5.4 of the Feekes scale (LARGE, 1954)) and stopped active growth. Then the shoots were cut off just above the ground, and after thoroughly loosening the soil and mixing the root systems through it, the pots were ready for a second crop. The same soil was used repeatedly, which is indicated as first cycle, second cycle, and so on. Fertilizer (NPK, 12-10-18) was applied from the second cycle on. The amount depended on the dry weight of the shoots harvested at the end of the previous cycle. Amounts of fertilizer added were 2, 3.5 and $5 \mathrm{~g}$, respectively, when the weights of shoots harvested were less than 2 , 2 to 10 , and over $10 \mathrm{~g}$ per pot.

\subsection{The greenhouse}

When the trial began in 1964, Ophiobolus was still assumed to spread only by substrates bearing active mycelium (stubbles and roots); air-borne spread of inoculum in a greenhouse was thus excluded and all trials were in the same greenhouse with inoculated and uninoculated pots together (FeLLows \& FICKE, 1939; KIRBY, 1922). But later on outbreaks of whiteheads occurred on sterilized or semisterile soils in uninoculated pots, suggesting air-borne infection. After that different greenhouse compartments were used whenever necessary. This will be indicated as separated greenhouse. In a separated greenhouse no crop which might harbour Ophiobolus, except the one under trial, was present. The greenhouse compartments used were controlled in temperature to $16^{\circ} \mathrm{C}$ but afternoon temperatures of $20^{\circ} \mathrm{C}$ were not uncommon through lack of the cooling capacity. On bright summer days the temperature could even rise to $23^{\circ} \mathrm{C}$. Relative humidity of the air fluctuated between 50 on bright hot days and 80 or sometimes $100 \%$ during the night. From the end of May until mid September, the inside of the greenhouse was shielded with cheesecloth, to cut down sunlight. From the end of November till the beginning of March from $06.00 \mathrm{~h}$ to $18.00 \mathrm{~h}$ light was supplemented by twelve $80-\mathrm{W}$, Bi-PIN, $4300^{\circ} \mathrm{K}$ fluorescent tubes, about 1 tube per sq. metre, at $75 \mathrm{~cm}$ above the soil or higher when necessary. 


\subsection{Soil}

Clay loam soils from East Flevoland were mostly used. Some data about the various soils are given in table 1. Each soil will be indicated by the number of the field in East Flevoland from which it comes, e.g. M 70. The Valthermond soil is the only one not from East Flevoland. The soil taken from Q 107 and $T 71$ was from below sand pumped onto those sites when the polder was still under water and dug away shortly before the time of sampling. Therefore no roots occurred in these soils. Contamination with surface soil was prevented as much as possible. These soils are indicated as subsoil clay. After being cropped once with wheat they lost their original character and were indicated further with the number of their field of origin only. Soil antagonizing Ophiobolus is called antagonistic soil. This will be explained in 5.2.3.

\subsection{Disease assessment}

The fungus can readily be isolated from not too old roots attacked by Ophiobolus, especially when surface-sterilizing the roots with $1 \% \mathrm{AgNO}_{3}$ before plating them out on PDA (DAVIES, 1935). Though Ophiobolus does not produce perithecia on normal agar media it can be easily recognized by its characteristic growth pattern with curving hyphae at the border of the colony. With a little experience the runner hyphae of Ophiobolus, growing along the root, can be identified with certainty, when roots washed free of soil are observed under a $\times 50$ binocular dissecting microscope. This was generally used as a routine test for the presence of Ophiobolus, unless this was already apparent from macroscopic observation. To assess the frequency of

Table 1. Data about the soils used in the greenhouse trials.

\begin{tabular}{|c|c|c|c|}
\hline Origin & Type & Date of collection & Previous crops \\
\hline OFL 1 , field M 70 & clay loam & April 1965 & $\begin{array}{l}\text { fallow 1958; Medicago lupulina } 1959 \text {; } \\
\text { winter wheat 1960, barley } 1961 \text {; flax } \\
\text { 1962; grass (seed) 1963; winter wheat } \\
\text { 1964; peas } 1965 \text {. }\end{array}$ \\
\hline OFL, Q 107 & sandy loam & $\begin{array}{l}\text { May } 1965 \text { and } \\
\text { February } 1966\end{array}$ & $\begin{array}{l}\text { greyish virgin soil from the un- } \\
\text { aerated sublayers; no roots or animal } \\
\text { life; subsoil clay. }\end{array}$ \\
\hline $\begin{array}{l}\text { OFL, S } 6 \\
\text { OFL, T } 69\end{array}$ & $\begin{array}{l}\text { clay loam } \\
\text { clay loam }\end{array}$ & $\begin{array}{l}\text { April } 1965 \\
\text { August } 1966\end{array}$ & $\begin{array}{l}\text { reed until 1964; winter rape } 1965 \text {. } \\
\text { reed until } 1964 \text {; winter rape } 1965 \text {; } \\
\text { winter wheat } 1966 \text {. }\end{array}$ \\
\hline $\begin{array}{l}\text { OFL, T } 71 \\
\text { OFL, U } 43 \\
\text { Valthermond } \\
\text { (Province of Drente) }\end{array}$ & $\begin{array}{l}\text { clay loam } \\
\text { clay loam } \\
\text { reclaimed peat } \\
\text { soil, sandy, with } \\
15 \% \text { humus }\end{array}$ & $\begin{array}{l}\text { March } 1967 \\
\text { August } 1965 \\
\text { March } 1965\end{array}$ & $\begin{array}{l}\text { subsoil clay (explanation: see } Q 107 \text { ). } \\
\text { reed until } 1964 \text {; winter rape } 1965 \text {. } \\
\text { cultivated for many decades; pota- } \\
\text { toes } 1962 \text {; barley } 1963 \text {; winter wheat } \\
1964 \text {. }\end{array}$ \\
\hline
\end{tabular}

$1 \mathrm{OFL}=$ East Flevoland. 
Ophiobolus on the roots the following scale has been used:

$-=$ no runner hyphae on the roots

$+=$ runner hyphae on roots of $0-20 \%$ of the plants

$++=$ runner hyphae on roots of $20-50 \%$ of the plants

$+++=$ runner hyphae on roots of $50-100 \%$ of the plants.

For disease rating the following characters are considered:

1. overall condition of the plants, including length of plants and yellowing of the leaves;

2. condition of the root system.

Sometimes the dry weight of the shoots was measured. Since it rarely correlated well with the above two characters, it was of little value.

1. The overall condition of the plants was assessed by an arbitrary scale based on comparison of the diseased plants with healthy controls. Controls were given the index 0 , and dead plants the index 5 . Such a scale is appropriate for many different characters of many diseases (e.g. BOCKMANN, 1963; vON KALBEN, 1956). An illustration of plants one month old with the indexes $0-5$ is given in figure 1.

2. Root attack was estimated according to the same scale. The indexes of roots and shoots were closely correlated. An index 2 for the roots (i.e. dense growth of Ophiobolus with some browning of the roots, but the root system about as large as the control) corresponds to an index 0.5 for the shoots; since a plant does not always need its full root capacity (HULSHOFP, 1965), the shoots only show symptoms after root damage has passed a threshold value. Thus the scale 2-5 for the roots runs parallel with the scale $0.5-5$ for the shoots.

The overall condition of the shoots was chosen as the character for estimating the severity of the disease. It is indicated as disease index. Only with this character could

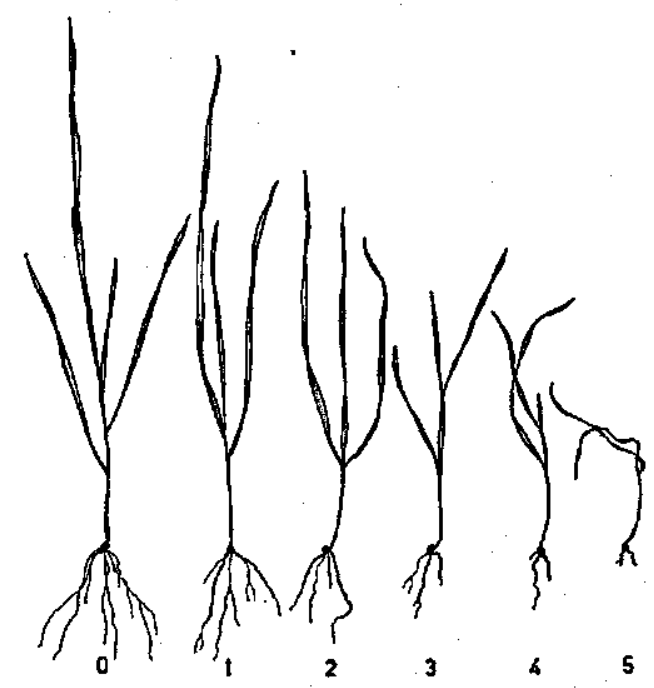

Fig. 1. Wheat plants, one month old, illustrating the disease indexes 0-5. 
the severity of attack be estimated at different moments during the growth of the same plants. In experiments of more than one cycle, in which the same soil had to be used again, so that each loss of soil and roots had to be avoided, the roots were not examined, except at the end of the last cycle. Thus the index for the roots was only occasionally estimated as a check on the disease index.

The time of assessment is very important in disease rating (TYNER \& BROADFOOT, 1943), because the disease index changes during the growing period. Therefore plants had to be assessed at least once in 3-4 weeks, in periods of rapid change even once a week.

The first symptoms of the disease are clearly visible 3 weeks after inoculation and sowing. After that the plants yellow progressively. From 1 to 2 months after sowing changes are generally less, though many plants die during this period, when attack is severe. After 2 months some plants often seem to recover. These plants generaily tiller and grow luxuriously, since death of most other plants leaves more space and nutrients for the surviving ones. This phenomenon makes disease assessment at 3 months after sowing of little value.

In the present paper, disease indexes are given per pot or box or as an average for all pots of the same treatment. They apply to the situation at about 2 months after sowing and are the average of the disease indexes of all plants, living and dead, unless 


\section{Introduction of Ophiobolus into the new polders}

After drainage the polder offers a big area of virgin soil without terrestrial life. Winged animals enter shortly after drainage. Land vertebrates, such as mice, enter the polder over dikes and bridges. Many plants, including pioneer vegetation and grasses, are introduced by air-borne and water-borne seeds (FEEKes \& BAKKER, 1954). Invertebrates, such as nematodes and mites, and also higher and lower plants are introduced inadvertently by man with soil particles adhering to machinery and roots of trees and shrubs planted in the polder. Spores of saprophytic or parasitic fungi may be borne by the air.

How Ophiobolus is entering is disputed, since it is not seed-borne, and its spread by ascospores is uncertain. We must examine how the mycelium or spores could be spread.

The mycelium of Ophiobolus can only be expected to be present on or in roots and stubble of cereals and grasses. Air-borne spread can be excluded; spread by man, animals or water is possible. Spread by man will be very restricted. Soil adhering to boots, machinery or planting material will seldom contain grass or stubble. Spread - by waterfowl is possible, but unlikely to happen often. Spread by other animals is even less likely. Thus, Ophiobolus could only be expected at very few places in the polder. Spread by water would imply the spread of Ophiobolus-carrying grasses by water before draining of the polders. This hypothesis was suggested for instance by OGILVIE \& THORPE (1962). Grass or fragments could be carried by water into the Ysselmeer, and could remain on the land surface after it is drained. If Ophiobolus is present on their roots the fungus could be introduced into the polder. But grass has rarely been found floating in the Ysselmeer. Thus spread on floating grass also seems unlikely. Spread of the fungus by spores is mentioned in 2.3. If Brooks (1964, 1965a) is correct that ascospores infect exposed roots of wheat seedlings, this has implications for the time of appearance of Ophiobolus in the polders, as discussed by GARRETr (1966). Since exposed seedling roots will be specially present when seeds, shed at harvest, are germinating upon the soil surface (volunteer plants), infection by ascospores can first be expected after the first cereal crop has been harvested.

Though Brooks (1965a) failed to infect grasses, it seems worthwhile not to exclude this possibility.

A last possibility which cannot be completely excluded, is the presence of Ophiobolus in the soil already before the polder is drained.

Summarizing, the theoretical possibilities give rise to four hypotheses:

1. spread by infected stubble or roots of grasses taken into the polder by man or animals; 
2. spread by infected parts of grasses (alive or dead) floating in the water of the Ysselmeer and remaining after drainage;

3. spread by air-borne ascospores;

4. presence in the virgin soil before draining.

To test these hypotheses the occurrence of Ophiobolus in different parts of East Flevoland and on the newly constructed artificial island Eemeiland was studied.

\subsection{Occurrence in different parts of East Flevoland}

East Flevoland was drained in 1957. When this study started in 1964, no newly drained soil was available, and Ophiobolus was already present everywhere in that part which had been cultivated for some years. However, this did not seem a serious disadvantage, since a large area was still covered with reed because of the stepwise reclamation of the polder. Distribution, at each stage after reclamation, of Ophiobolus on grasses along ditches and roads, and on wheat grown as a first and second crop after reed, should indicate the relevance of each hypothesis.

\subsubsection{Ophiobolus on grasses}

At different sites in East Flevoland samples of grasses were collected. Generally 10 clumps were sampled at each site. If other than 10 clumps the sample size is indicated (table 2). By a clump is meant a small group of grass plants growing together or a sod about $15 \mathrm{~cm}$ by $15 \mathrm{~cm}$. Within 2 days of sampling some of the roots of each clump were examined for runner hyphae of Ophiobolus. Sometimes, especially if Ophiobolus had not been found, the clumps were put into boxes and covered with a thin layer of steamed river sand. The boxes were sown with 50 wheat seeds each and kept for about $1 \frac{1}{2}$ month in a separate greenhouse. Then the wheat plants were uprooted and the roots screened for the presence of Ophiobolus (wheat seedling test). Owing to this procedure amounts of Ophiobolus, apparently so small that they were overlooked on grass roots, could be demonstrated. Data on the presence of Ophiobolus at a number of sites, the vegetation of these sites and the time of reclamation (clearance of reed) are given in table 2. The sites are indicated in figure 2. For comparison three sites outside East Flevoland were also sampled. They too are recorded in
table 2 .

This experiment shows that $O$ phiobolus occurs regularly on roots in a closed grass vegetation. When grasses are still growing in separate clumps, shortly after reclamation, Ophiobolus is rarely found. Since samples were rather small, this does not yet prove that Ophiobolus is really absent. Grasses growing along lakesides, washed ashore or possibly washed ashore, never carried Ophiobolus (last 5 sites of table 2).

\subsubsection{Ophiobolus in first wheat crops}

In East Flevoland wheat is normally grown as the second agricultural crop, directly 
Table 2. Ophiobolus on grasses at various sites.

\begin{tabular}{|c|c|c|c|c|c|}
\hline \multirow[t]{2}{*}{ Site } & \multirow[t]{2}{*}{ Date } & \multirow{2}{*}{$\begin{array}{l}\text { No. of } \\
\text { years } \\
\text { since } \\
\text { clear- } \\
\text { ance } \\
\text { of reed }\end{array}$} & \multirow[t]{2}{*}{ Vegetation } & \multicolumn{2}{|c|}{$\begin{array}{l}\text { Occurrence of } \\
\text { Ophiobolus } 5\end{array}$} \\
\hline & & & & visual & $\begin{array}{l}\text { wheat } \\
\text { seedling } \\
\text { test }\end{array}$ \\
\hline Kampernieuwstad ${ }^{\mathfrak{1}}$ & Nov. '66 & $?$ & $\begin{array}{l}\text { permanent grassland bordering lake, } \\
\text { sown about } 6 \text { years before }\end{array}$ & + & + \\
\hline NOP $^{2}$, Emmeloord & May '67 & $>20$ & closed roadside grass mat & ++ & \\
\hline NOP, Vollenhove & May '67 & $>20$ & closed roadside grass mat & ++ & +++ \\
\hline $\mathrm{OFL}^{3}, \mathrm{Y} 90$ & Oct. '66 & 9 & $\begin{array}{l}\text { closed grass mat, lakeside slope of } \\
\text { dike }\end{array}$ & +++ & \\
\hline OFL, Y 90 & Oct. '66 & 9 & $\begin{array}{l}\text { closed grass matt, landside slope of } \\
\text { dike }\end{array}$ & $++t$ & \\
\hline OFL, R 26/27 & Jan. "67 & 6 & closed roadside grass mat & +++ & \\
\hline OFL, R 26 & Oct. '66 & 5 & closed roadside grass mat & +++ & \\
\hline OFL, X 15 & Oct. '66 & 4 & closed roadside grass mat & ++ & \\
\hline OFL, T 20 & Oct. '66 & 3 & closed roadside grass mat & + & \\
\hline OFL, S 6 north & Aug. '65 & 1 & $\begin{array}{l}\text { grasses on ditchsides, nearly closed } \\
\text { grass mat, neighbouring roadsides } \\
\text { sown with grass in } 1961\end{array}$ & $++t$ & +++ \\
\hline OFL, U 67 south & July '66 & 1 & grasses in clumps on ditchsides & +++ & \\
\hline OFL, U 67 south & Aug. '66 & 1 & $\begin{array}{l}\text { grasses in clumps on ditchsides and } \\
\text { in wheat field }\end{array}$ & ++ & \\
\hline OFL, U 60 & Jan. '67 & 1 & grasses in clumps on ditchsides & + & \\
\hline OFL, U 60 & May '67 & 1 & roadside; grass mat not yet closed & - & $t$ \\
\hline OFL, B 20 & May'67 & 0 & grasses in clumps at roadside & - & \\
\hline OFL, D 13 & Aug. '66 & 0 & $\begin{array}{l}20 \text { small grass clumps along ditch } \\
\text { and in dense reed field (reed still } \\
\text { present) }\end{array}$ & - & \\
\hline \multicolumn{6}{|l|}{$\begin{array}{l}\text { Lakeside of dike } \\
\text { in OFL near: }\end{array}$} \\
\hline$\times 47$ & Oct. '66 & 94 & $\begin{array}{l}\text { grasses growing in clumps on beach } \\
\text { sand, possibly previously washed } \\
\text { ashore }\end{array}$ & - & \\
\hline Y 90 & Oct. '66 & - & $\begin{array}{l}\text { grasses growing between bricks at } \\
\text { base of dike }\end{array}$ & 一 & \\
\hline Z 88 & Oct. '66 & $\bullet$ & $\begin{array}{l}7 \text { small clumps growing at base of } \\
\text { dike, possibly washed ashore }\end{array}$ & - & \\
\hline Z 88 & Oct. '66 & - & $\begin{array}{l}4 \text { small clumps between rubbish at } \\
\text { base of dike, certainly washed } \\
\text { ashore (still alive) }\end{array}$ & - & \\
\hline X 32-Q 122 & Nov. '66 & • & $\begin{array}{l}20 \text { small clumps growing at base of } \\
\text { dike, possibly washed ashore }\end{array}$ & - & - \\
\hline
\end{tabular}

1 Village on old land near Kampen.

${ }^{2}$ NOP $=$ North-East Polder.

3 OFL $=$ East Flevoland.

- $=$ previously no reed.

5 - : no Ophiobolus; + : Ophiobolus on $<20 \%$ of plants; ++ : on $20-50 \%$ of plants;

+++ : on $>50 \%$ of plants. 
following winter rape. In this first wheat crop Ophiobolus generally only occurs in a few scattered patches, mostly of a few wheat plants, especially at the borders of the field. In field trials whiteheads were used as the criterion for the occurrence of Ophiobolus. If doubtful, the presence of Ophiobolus was proved by inspecting the roots.

Some trials were on the distribution of Ophiobolus in first wheat crops.

In 1965 a first crop of winter rape was grown on field $S 6$ after several years of reed. At the north side of this field strips 300 metres long and 2 metres wide were cleared in spring and sown with spring wheat as indicated in figure 3. Some weeks before ripening of the wheat about $2 \%$ of the plants in the strip bordering the ditch had whiteheads. In the other strips not more than $0.1 \%$ whiteheads occurred. But this number is still higher than usual in a first wheat crop after rape.

In 1966 Ophiobolus was found in another field with wheat directly following reed (U 67). Part of the field was used as a trial field by the Ysselmeer Polders Development and Settlement Authority (for other purposes) and sown with wheat. The north-east

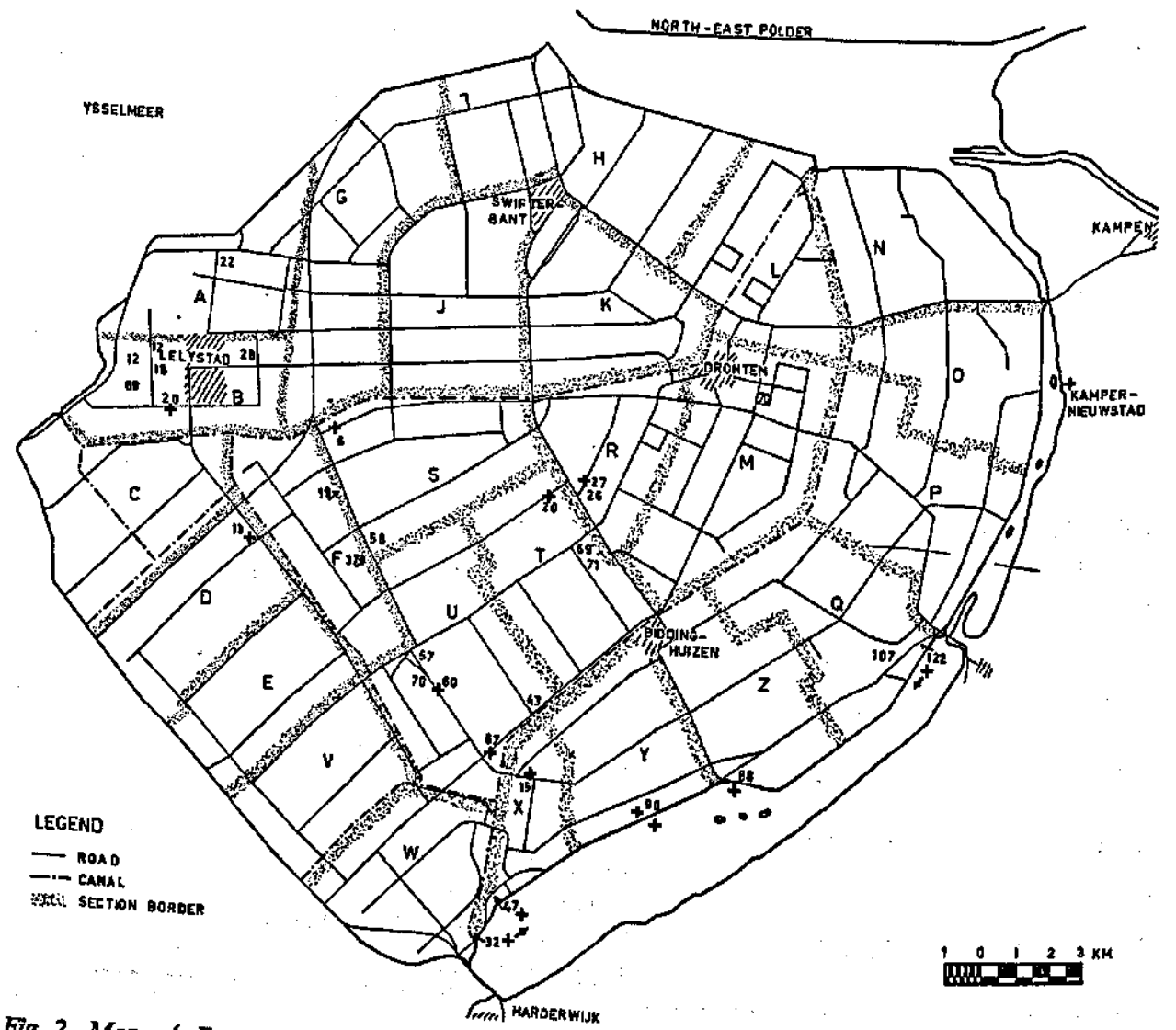

Fig. 2. Map of East Flevoland. Grass samples were taken at sites indicated with +. Courtesy 


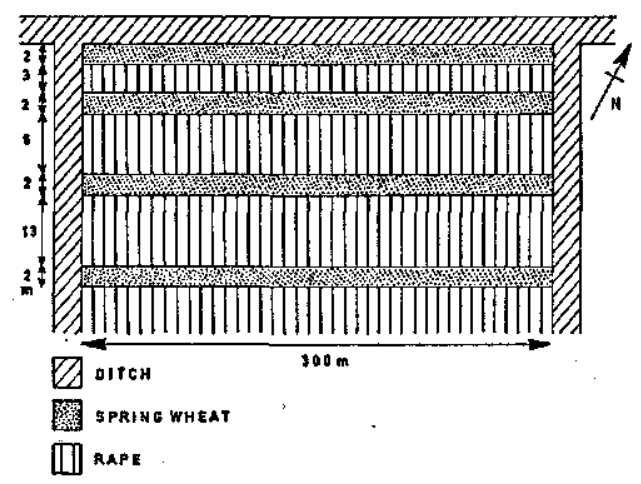

Fig. 3. Position of strips of spring wheat in a rape field, $S 6$, in East Flevoland.

of the field was sown with rape (fig. 4). In 1966 winter wheat contained many whiteheads, not only at the border of the field near the ditch but also in the middle of the field, both up to about $5 \%$. In 1967 winter wheat was grown on the north-east part of the field, following rape. In this crop Ophiobolus only occurred near the border of the field along the ditch (about 5\% whiteheads) and not inside the field (fig. 4).

In 1967 the frequency of whiteheads along the roadside and inside the field was also assessed in other fields of wheat following reed or rape. Whiteheads were counted in equal lengths of the first three rows of wheat along the ditch and in three rows, 3 metres inside the field (table 3). When wheat followed rape, many more patches of whiteheads were found along the border than inside the field. Such a difference was
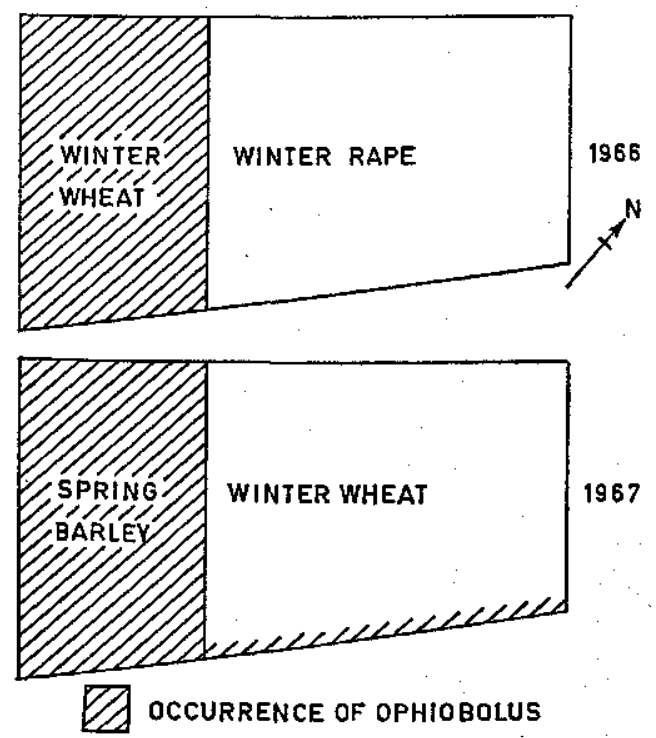

Fig. 4. Occurrence of Ophiobolus in wheat and barley in 1966 and 1967; East Flevoland, field U 67. 
not found when wheat was grown directly after reed, in which case the number of patches in the fields recorded in table 3 was far smaller than in the fields $S 6$ and $U 67$.

\subsubsection{Discussion}

1. On fields U 67 and S 6 Ophiobolus occurred more frequently on wheat as a first crop than as a second crop after rape. This strongly suggests the direct transmission of Ophiobolus from the reed roots left in the soil after reclamation. Support for this view comes from a chance observation. I uprooted a whiteheaded wheat plant in a field of wheat grown directly after reed and, entangled in its root system, was a piece of reed stolon. Both reed and wheat roots carried runner hyphae.

When Ophiobolus is present on reed, rape will serve as a break-crop and the inoculum level of Ophiobolus decreases. Therefore a lower incidence of Ophiobolus on wheat after rape may be expected. On field $S 6$ the strips of wheat had been sown in spring after a soil cover of rape during winter only. This might explain why $\mathbf{S} 6$ had less Ophiobolus than U 67 where wheat directly followed reed but more than where wheat is a second crop. The low incidence of $O$ phiobolus in wheat after reed on fields reported in table 3 is difficult to explain. It might be that the reed was less infected because of soil conditions since the time of drainage, which would be important. But even on $\mathrm{S} 6$ and to a lesser extent on U 67 there was less Ophiobolus than might have been expected, since reed had grown on these fields for many years. Apparently, reed is not a very good carrier and does not build up the inoculum level severely.

2. The distribution of Ophiobolus in wheat grown after rape indicates a very clear border effect (U 67; S 6; table 3). Grasses, established directly after reclamation, usually along ditches and roads, can, like wheat, take over Ophiobolus from the reed. Ophiobolus was sometimes found within a year of reclamation on grasses growing as

Table 3. Number of patches of whiteheads in wheat after reed or rape along the border and inside the field (in $100 \mathrm{~m}$ lengths of 3 rows).

\begin{tabular}{|c|c|c|c|c|c|}
\hline \multirow[t]{2}{*}{ Site } & \multicolumn{2}{|c|}{ Wheat after reed } & \multirow[t]{3}{*}{ Site } & \multicolumn{2}{|c|}{ Wheat after rape } \\
\hline & along border & inside field & & along border & inside field \\
\hline A 22 & 1 & & & & \\
\hline B 12 & $\begin{array}{l}1 \\
0\end{array}$ & $\begin{array}{l}0 \\
0\end{array}$ & F 19 & 18 & 3 \\
\hline B 17 & 0 & 0 & F 37 & 13 & $\mathbf{0}$ \\
\hline B 18 & 0 & 3 & S 58 & 19 & 0 \\
\hline B 20 & $\begin{array}{l}0 \\
0\end{array}$ & 0 & U 57 & 8 & $\mathbf{0}$ \\
\hline B 28 & $\begin{array}{l}0 \\
0\end{array}$ & 4 & U $57^{1}$ & $\mathbf{0}$ & 0 \\
\hline B 69 & & 0 & U 70 & 2 & 0 \\
\hline & & 0 & $\mathrm{U} 70^{1}$ & 0 & 0 \\
\hline
\end{tabular}


separate clumps (table 2). Later than one year after reclamation grasses form a closed vegetation on the ditchsides and the verges of the roads, which is entirely infected by Ophiobolus (table 2). Thus Ophiobolus spreads much more extensively on grass than on reed. The preservation and expansion of Ophiobolus on ditchside grasses and the death of most $O$ phiobolus inside the field under rape are responsible for the border effect. It will be clear that such a border effect cannot occur in a first wheat crop directly after reed.

The problem is therefore how Ophiobolus infects the reed. The observations do not provide much information about the four hypotheses on the introduction of Ophiobolus. Ophiobolus is too generally present too early to make incidental spread by man or animals likely. The very early occurrence on grass before wheat is sown also excludes the possibility that $O$ phiobolus is introduced by ascospore infection of wheat. This does not exclude the possibility that ascospores infect wheat; it only diminishes its possible importance since Ophiobolus is already present (cf. Brooks, 1965a).

The opportunity then arose to investigate how reed becomes infected.

\subsection{Occurrence on Eemeiland}

In 1964-1965 the Dienst der Zuiderzeewerken (Board of Zuyder Sea Works) constructed an artificial island (Eemeiland) for experiments. This island is situated in the lake south of the dike of South Flevoland and about $11 / 2 \mathrm{~km}$ from old land. On the old land opposite the island meadows predominate but some wheat is grown near the mouth of the River Eem. (I have not attempted to estimate the relative importance of grass or wheat as a possible source of Ophiobolus ascospores). The dike of the island was constructed in 1964. After that the island was made by pumping sludge (loam) from the bottom of the Ysselmeer into the space within the dike. This was finished late in the summer of 1965. The centre of the island was sown with reed and the dike with a mixture of grasses in April and May 1966, respectively. This island offered a good opportunity for investigating the first occurrence of Ophiobolus on virgin land, because:

1. grasses in the centre of the island can only originate from seed, since it has not been flooded by water;

2. man can only reach the island by boat thus making the introduction of grasses with Ophiobolus highly improbable;

3. no wheat had been grown on the island.

In winter 1967 the dike carried a closed grass vegetation, the centre was mainly covered with reed, but some open sites had separate clumps of grasses and weeds, mostly introduced by air-borne seeds. The grasses (except reed) have been sampled regularly from January 1967 onwards. The method used was the same as for East Flevoland (4.1.1). The results are listed in table 4. The numbers of the sites can be found on the map of the island (fig. 5). Table 4 clearly shows the presence of Ophiobolus all over Eemeiland and also on the dike of the future South Flevoland. With 
the exception of the grass mat 2 years old on the dike and recreation turf of South Flevoland, Ophiobolus, though present nearly everywhere, was not abundant. It was never observed on the grass roots of samples from the island, but was trapped several times by seedling tests. It is remarkable that all sites already harboured Ophiobolus. However, the density is still low as shown by the + (table 4 ) and by the fact that it is not always found on both sampling dates.

In spring 1967 small plots of wheat were sown with spring wheat to further check the presence of Ophiobolus on Eemeiland. Each plot measured about 10 sq. metres. On 30 March plots were sown on sites 1, 2 and 3 (on site 3, there were 2 plots close together: $3 \mathrm{a}$ and $3 \mathrm{~b}$ ). On 19 April plots were sown on sites 5, 6,7 and 8. Plot 8 was on the top of the dike and the slope to the lakeside. Due to the dry weather the plots on sandy soil $(1,2,5$ and 8$)$ suffered starvation and drought and were dead at the end of July. Random samples were taken of the plants of all plots on 27 July and 17 August. No symptoms were observed. Root-screening in the laboratory, however, showed that Ophiobolus was usually present in small amounts (table 5), thus confirming the results of the grass samples. Here too the density of Ophiobolus seemed low.

The observations and results of trials so far yield the following information about the four hypotheses on the introduction of Ophiobolus into new areas.

Table 4. Ophiobolus on grasses (except reed) on Eemeiland ${ }^{1}$ and elsewhere.

\begin{tabular}{|c|c|c|c|c|c|c|}
\hline \multirow[t]{2}{*}{ Site } & \multicolumn{2}{|l|}{ Situation } & \multicolumn{2}{|c|}{$\begin{array}{l}\text { First sampling } \\
\text { (January '67) }\end{array}$} & \multicolumn{2}{|c|}{$\begin{array}{l}\text { Second sampling } \\
\text { (March-April '67) }\end{array}$} \\
\hline & & . & visual & $\begin{array}{l}\text { wheat } \\
\text { seedling } \\
\text { test }\end{array}$ & visual & $\begin{array}{l}\text { wheat } \\
\text { seedling } \\
\text { test }\end{array}$ \\
\hline 1 & $\begin{array}{l}\text { end of sand-filling pipe, near dike, } \\
\text { sandy soil with many shells }\end{array}$ & grasses & - & + & - & - \\
\hline 2 & lakeside, sandy slope of dike & in & - & + & - & - \\
\hline 3 & very wet loamy soil & separate & - & + & - & + \\
\hline 4 & $\begin{array}{l}\text { end of sand-filling pipe, near dike, } \\
\text { sandy soil with many shells }\end{array}$ & clumps & - & - & - & + \\
\hline 5 & lakeside slope and top of dike & closed & - & - & - & + \\
\hline 6 & lakeside slope of dike & grass mat & - & + & - & + \\
\hline $\begin{array}{l}\text { Several } \\
\text { places }\end{array}$ & $\begin{array}{l}\text { Floating grasses washed ashore, } \\
\text { still alive }\end{array}$ & & - & - & & $T$ \\
\hline Dike a & $\begin{array}{l}\text { grasses in clumps on dike of South } \\
\text { Flevoland opposite Eemeiland }\end{array}$ & & & . & - & - \\
\hline & $\begin{array}{l}\text { dike of South Flevoland opposite } \\
\text { Spakenburg }{ }^{2}\end{array}$ & $\begin{array}{l}\text { closed } \\
\text { grass mat }\end{array}$ & & & +++ & $++t$ \\
\hline & $\begin{array}{l}\text { recreation turf adjoining dike } \\
\text { opposite Spakenburg }\end{array}$ & $\begin{array}{l}\text { sown } \\
\text { in } 1965\end{array}$ & & & $++t$ & $+t+$ \\
\hline
\end{tabular}

1 Sown in May 1966.

2 Village on old land (see figure 5).

Key: see table 2. 


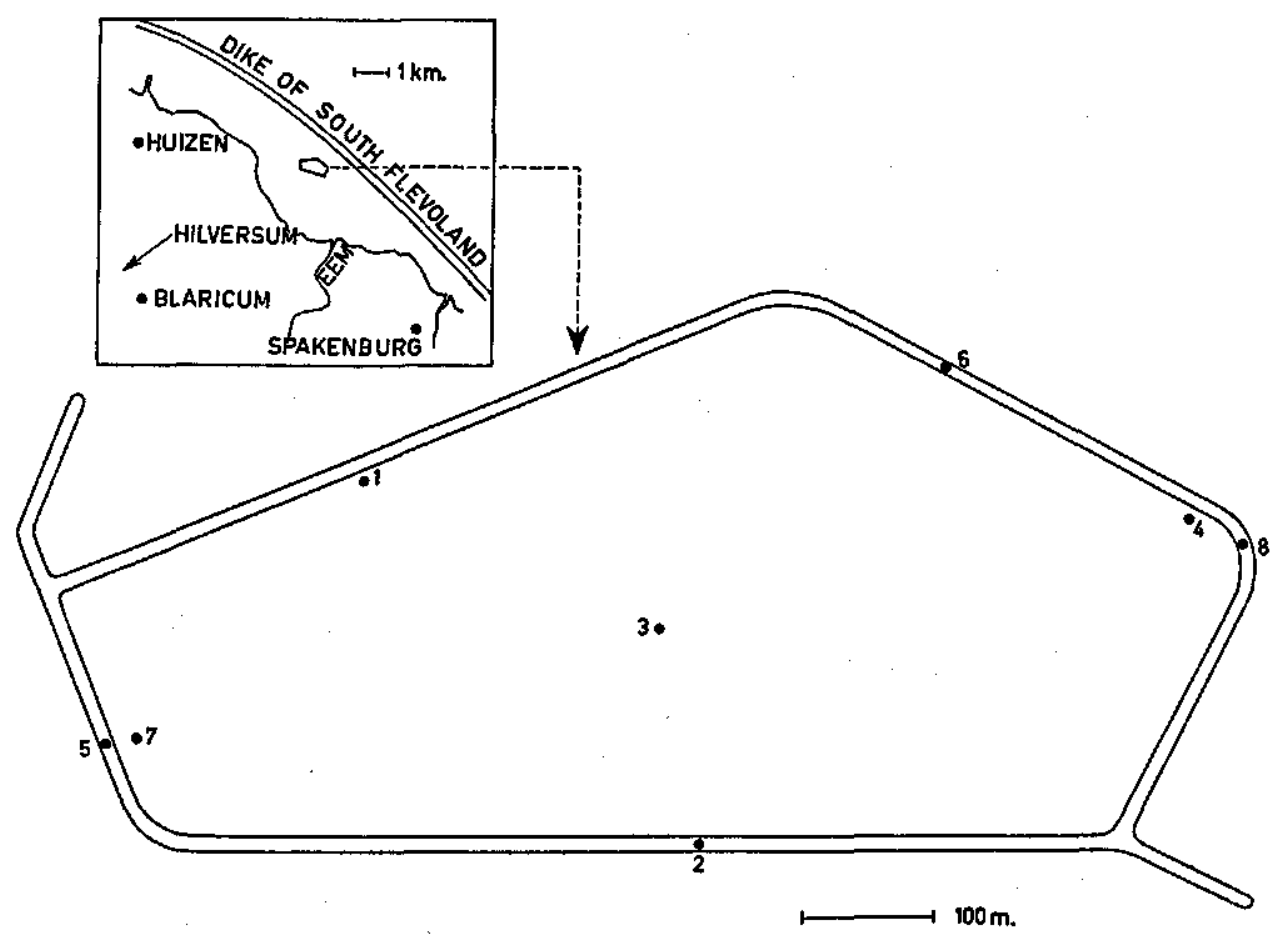

Fig. 5. Map of Eemeiland with sites of grass samples and wheat plots. Courtesy Rijksdienst voor de IJsselmeerpolders.

Table 5. Ophiobolus on roots of wheat from sites on Eemeiland.

\begin{tabular}{|c|c|c|c|c|}
\hline \multirow[t]{2}{*}{ Site } & \multicolumn{2}{|c|}{ Sampling date 27 July 1967} & \multicolumn{2}{|c|}{ Sampling date 17 August 1967} \\
\hline & $\begin{array}{l}\text { number of } \\
\text { plants }\end{array}$ & $\begin{array}{l}\text { occurrence of } \\
\text { Ophiobolus }\end{array}$ & $\begin{array}{l}\text { number of } \\
\text { plants }\end{array}$ & $\begin{array}{l}\text { occurrence of } \\
\text { Ophiobolus }\end{array}$ \\
\hline 1 & 35 & + & 66 & + \\
\hline 2 & 56 & - & 84 & - \\
\hline $\mathbf{3 a}$ & 7 & - & 60 & - \\
\hline 3b & 7 & - & 64 & - \\
\hline 5 & 31 & - & 69 & + \\
\hline 6 & 16 & + & 52 & - \\
\hline 7 & 27 & + & 47 & - \\
\hline 8 & 35 & - & 56 & + \\
\hline
\end{tabular}

Key: see table 2.

Site: see fig. 5. 
1. The widespread occurrence of Ophiobolus so soon after drainage or reclamation makes introduction by man or animals very unlikely.

2. The Ophiobolus on grasses on Eemeiland could not have spread from infected grasses floating to it from old land, since the island is above water-level. Anyway Ophiobolus was never observed on grasses washed ashore or possibly washed ashore. 3. Therefore spread of $O_{p}$ hiobolus by ascospores seems now the most likely explanation for the infection of grasses as observed in East Flevoland and on Eemeiland ${ }^{3}$. 4. Though the presence of Ophiobolus in virgin soil is very improbable, the opportunity to test this hypothesis, which presented itself, was seized (4.3).

Trials still to be described could not demonstrate Ophiobolus in virgin soil. But these trials strongly supported the assumption of infection by air-borne ascospores (4.3.1 and 4.3.2).

\subsection{Infection experiments with wheat and grasses growing in subsoil clay}

\subsubsection{Experiments in the greenhouse}

Though absolute proof of the absence of Ophiobolus in subsoil clay would be difficult, evidence of its absence was sought in greenhouse trials.

In a preliminary trial with live (LO), dead (DO) or no (NO) Ophiobolus (see 3.1), each in 3 Mitscherlich pots, at maturity wheat proved to be infected with Ophiobolus not only in LO, but also in the controls DO and NO. These quite unexpected results could have two meanings.

1. Ophiobolus is present in the subsoil clay (owing to a highly improbable contamination with surface soil or to its natural occurrence).

2. Infection with Ophiobolus takes place with ascospores from a source in the greenhouse.

Therefore with a new soil sample a second experiment according to the following scheme was arranged in two duplicate series:

\begin{tabular}{l|l|l} 
Sresh & LO (1 pot) \\
& NO (3 pots) \\
autoclaved $\left(2 \mathrm{~h}\right.$ at $\left.120^{\circ} \mathrm{C}\right)$ & LO (1 pot) \\
NO (3 pots)
\end{tabular}

Sand, autoclaved

LO (1 pot)

NO (3 pots) 
The first series of treatments including controls was kept in the greenhouse continuously used for experiments with Ophiobolus (I). The LO treatments of the second series were placed in a separate greenhouse (II), and the NO treatments of this series in another greenhouse (III). In the first crop aerial parts of some wheat plants showed symptoms of Ophiobolus $31 / 2$ months after sowing. (The roots were not examined.) The results are shown in table $6 \mathrm{~A}$. Ophiobolus occurred in uninoculated pots only in greenhouse I.

Since even the LO treatments showed only mild symptoms the same pots were treated the same again to get a better impression of the presence or absence of Ophiobolus. After 3 months roots were examined in the usual way (table $6 \mathrm{~B}$ ).

The pots of treatment NO with fresh and autoclaved subsoil clay were resown with wheat for a third cycle and all put into greenhouse I. After 4 months the presence of Ophiobolus on the roots was determined (table $6 \mathrm{C}$ ).

Two successive crops grown on subsoil clay in greenhouse III free from Ophiobolus remain healthy. It proves that Ophiobolus is not naturally present in this subsoil. Uninoculated wheat grown as a first crop on either fresh or autoclaved subsoil or sand in greenhouse I, where experiments with Ophiobolus were continuously carried out, may show symptoms of Ophiobolus. This suggests spread of Ophiobolus in the greenhouse by ascospores.

To get more evidence a third experiment was set up. Pots were filled with subsoil clay and sown with wheat, Lolium perenne or Poa annua. After a week $50 \mathrm{ml}$ glass beakers half full of moist sand were placed on the soil surface in the centre of half of the pots. Wheat stubble with ripe perithecia of Ophiobolus was stuck into the beakers so that part reached over the rim. Every time the plants were watered, the perithecia got wet. Half the pots, with or without stubble, were placed in greenhouse I normally used for trials with Ophiobolus. From the other half the pots with stubble were put in separate greenhouse II, and those without into another separate greenhouse (III). Each treatment consisted of 2 pots. On spore traps (glass slides) exposed between the plants some ascospores of Ophiobolus were caught in the course of some weeks, only in greenhouse I and II and not in greenhouse III. Shoots and roots were screened for Ophiobolus $31 / 2$ months after the trial began (table 7 ). Only a few roots per pot were examined, leaving the others in place. Seed of Poa annua germinated very poorly, leaving 4 pots empty (not included in the table) and 4 bearing only a few plants. After the observations, aerial parts of the plants were cut off just above the soil surface. The beakers with stubble were taken away. The soil and root systems were thoroughly mixed in each pot with $L$. perenne and $P$. annua, and with wheat from greenhouse III. Then wheat was sown and the pots were all put in separate greenhouse III, to see whether Ophiobolus appeared. Table 7 shows that wheat, L. perenne and $P$. annua, grown on subsoil clay, are easily infected by ascospores of Ophiobolus.

${ }^{3}$ Observations on the occurrence of Ophiobolus on wheat in East Flevoland from 1958 on already led JONKER (personal communication) to suppose infection by air-borne ascospores. 


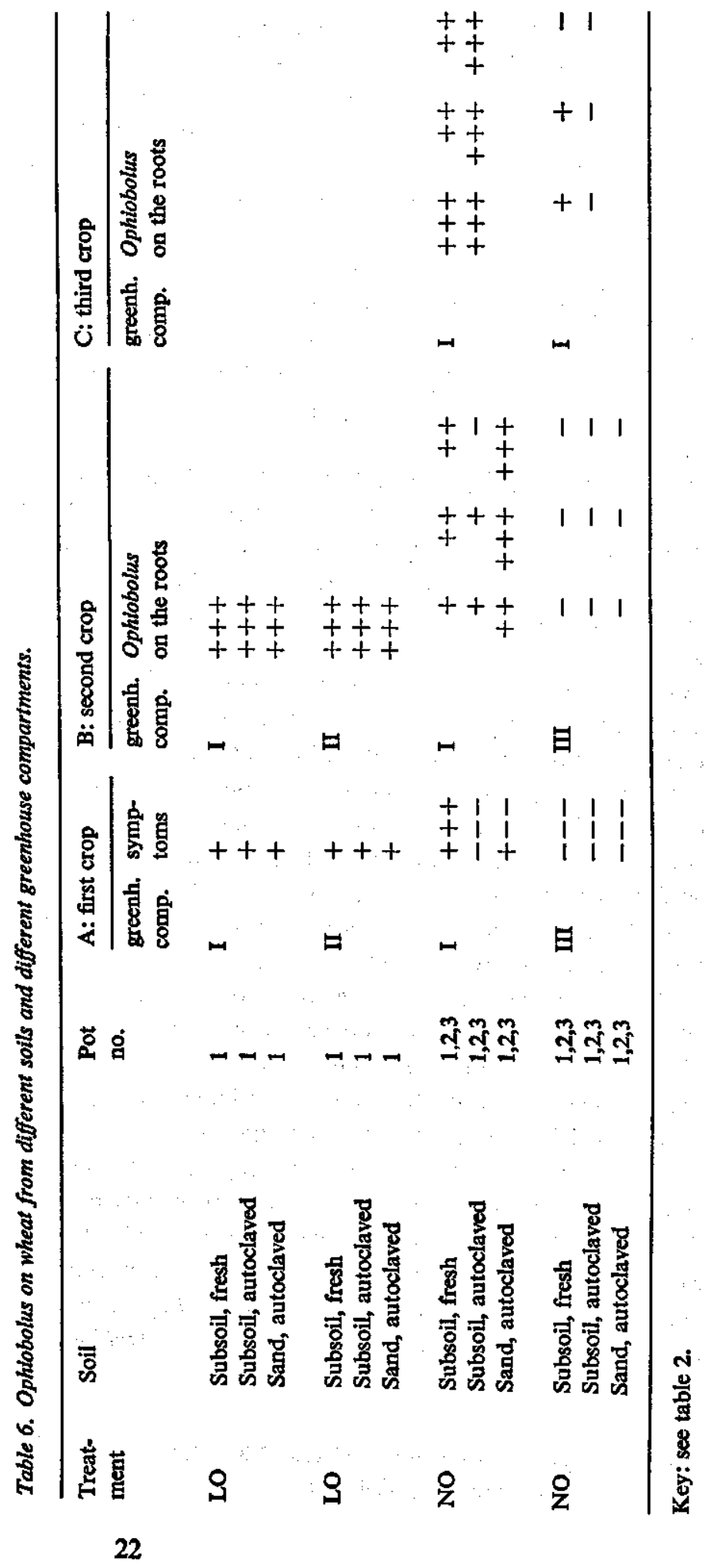


Table 7. Ascospore infection of wheat and grasses growing in subsoil clay.

\begin{tabular}{|c|c|c|c|c|c|c|c|c|}
\hline \multirow{3}{*}{$\begin{array}{l}\text { Green- } \\
\text { house } \\
\text { com- } \\
\text { partment }\end{array}$} & \multirow{3}{*}{$\begin{array}{l}\text { Stubble with } \\
\text { perithecia }\end{array}$} & \multirow{3}{*}{ Crop } & \multicolumn{4}{|c|}{$\begin{array}{l}\text { Presence of Ophiobolus } \\
\text { (examined visually) }\end{array}$} & \multirow{2}{*}{\multicolumn{2}{|c|}{$\begin{array}{l}\text { Presence of } \\
\text { Ophiobolus (wheat } \\
\text { seedling test) }\end{array}$}} \\
\hline & & & \multicolumn{2}{|l|}{ shoots } & \multicolumn{2}{|l|}{ roots } & & \\
\hline & & & pot 1 & pot 2 & pot 1 & pot 2 & pot 1 & pot 2 \\
\hline$I$ & + & $\begin{array}{l}\text { wheat } \\
\text { Lolium }\end{array}$ & +++ & $++t$ & $\begin{array}{r}++ \\
\end{array}$ & $\begin{array}{r}++ \\
-\end{array}$ & + & + \\
\hline I & - & $\begin{array}{l}\text { wheat } \\
\text { Lolium } \\
\text { Poa }\end{array}$ & $+t+$ & $\begin{array}{r}++ \\
:\end{array}$ & $\begin{array}{r}++1 \\
:\end{array}$ & $\begin{array}{r}++ \\
-\end{array}$ & $\begin{array}{l}+ \\
+\end{array}$ & $\begin{array}{l}+ \\
+\end{array}$ \\
\hline II & + & $\begin{array}{l}\text { wheat } \\
\text { Lolium } \\
\text { Poa }\end{array}$ & +++ & ++ & $\begin{array}{r}++ \\
\end{array}$ & $\begin{array}{r}++ \\
-\end{array}$ & $\begin{array}{r}++ \\
++\end{array}$ & $\begin{array}{r}++ \\
++\end{array}$ \\
\hline III & - & $\begin{array}{l}\text { wheat } \\
\text { Lolium }\end{array}$ & - & - & $\because$ & $\stackrel{-}{\circ}$ & $\begin{array}{l}- \\
-\end{array}$ & - \\
\hline
\end{tabular}

1 all tests in greenhouse III.

- = Not recorded, because no symptoms were expected.

- Roots not sampled.

Key: see table 2.

\subsubsection{Infection of wheat in subsoil clay in the open air}

In East Flevoland field R 27 at the end of May 1965 a hole was dug 8 metres by 2.5 metres, and 1 metre deep about 20 metres north-east of a trial plot where Ophiobolus regularly occurred. Half the hole was lined with plastic to stop grass roots entering it and it was all filled with subsoil clay from field Q 107. Around the lined half a zone 0.75 metre wide was kept clear of grass and weeds. At the end of October 1965 winter wheat was sown in rows on the cloddy soil. An apparently healthy crop was harvested in 1966, but the roots were not examined. In October 1966 the soil was resown with winter wheat. Though a lot of plants died over winter the cause did not seem to be Ophiobolus. In spring larger gaps were resown with spring wheat. From 28 June 1967 some plants developed whiteheads. Blackened roots confirmed the presence of Ophiobolus. The occurrence of diseased plants all over the plot (fig. 6) is strong evidence, that $O$ phiobolus spread by spores rather than by root contact with surrounding grasses.

\subsection{Discussion and conclusions on the spread of Ophiobolus}

Observations and trials on the occurrence of Ophiobolus in the first years after reclamation of a polder do not accord with any of the current theories in literature about the spread of Ophiobolus but confirm the course of events discussed by Brooks 
(1965a) as 'possibility'. Evidence has accumulated that air-borne ascospores have introduced Ophiobolus into the new polders. Unfortunately, trapping of ascospores in the polders was not practicable, but GreGory \& Stedman (1958) and SAMUeL \& GARRETT (1933) have observed many ascospores in the air over some fields with perithecia-bearing wheat stubble. The crucial point is the easy infection of wheat and grasses when grown on semisterile soil.

During the first years after drainage, the structure and moisture content of polder soil restrict the number of micro-organisms (VAN SCHREVEN, 1962). Though GARRETT (1939) found ascospores infective only under completely sterile conditions, FeLLows \& FICKE (1939) reported ascospore infection of wheat in sterilized soil which was not kept sterile. HIRST (1965) even obtained infection in a loam-sand mixture which was not sterilized. My trials suggest the possibility of infection when few micro-organisms are active, as in the first years after drainage of the polders. Even after 6 months under two crops of wheat in the greenhouse, ascospore infection could occur (table $6 \mathrm{C}$ ). Also, the frequent occurrence of Ophiobolus in untreated controls in trials still to be described, on normal soil, makes it doubtful whether in all these cases Ophiobolus was present in the soil used. When I applied a suspension of ascospores to the roots of wheat plants growing in root observation boxes (GERLAGH, 1966) filled with subsoil clay or normal soil, germination hyphae of the ascospores differed in the amount of lysis, according to soil type. Infection was inversely correlated with lysis: lysis was least in boxes with subsoil clay, and most plants got infected; with normal soil only few plants got infected.

Reclaimed land in the polders has, to some extent, matured under reed before wheat is sown. Before the reed covers the soil a vegetation of weeds, including many grasses, develops. The possibility of ascospore infection of grasses has been demonstrated (table 7). Thus reed may perpetuate $O$ phiobolus as it replaces the weeds. It is not known whether ascospores can directly infect reed but this is unlikely since reed seems to be a poorer carrier. Although I did not study whether ascospores infect the wheat crop grown after reed or rape, all observations can be explained without assuming it (see also 4.1.3).

Under rape, as a first agricultural crop, much of the inoculum on the reed roots decomposes. Only grass on the verges of roads and ditchsides provides a good

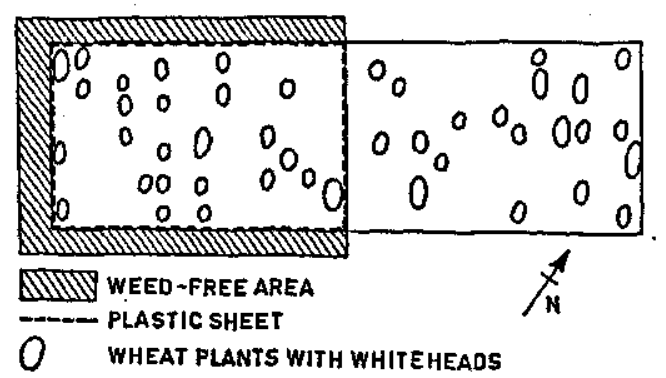

Fig. 6. Distribution of Ophiobolus-infected wheat plants grown on subsoil clay in the open. 


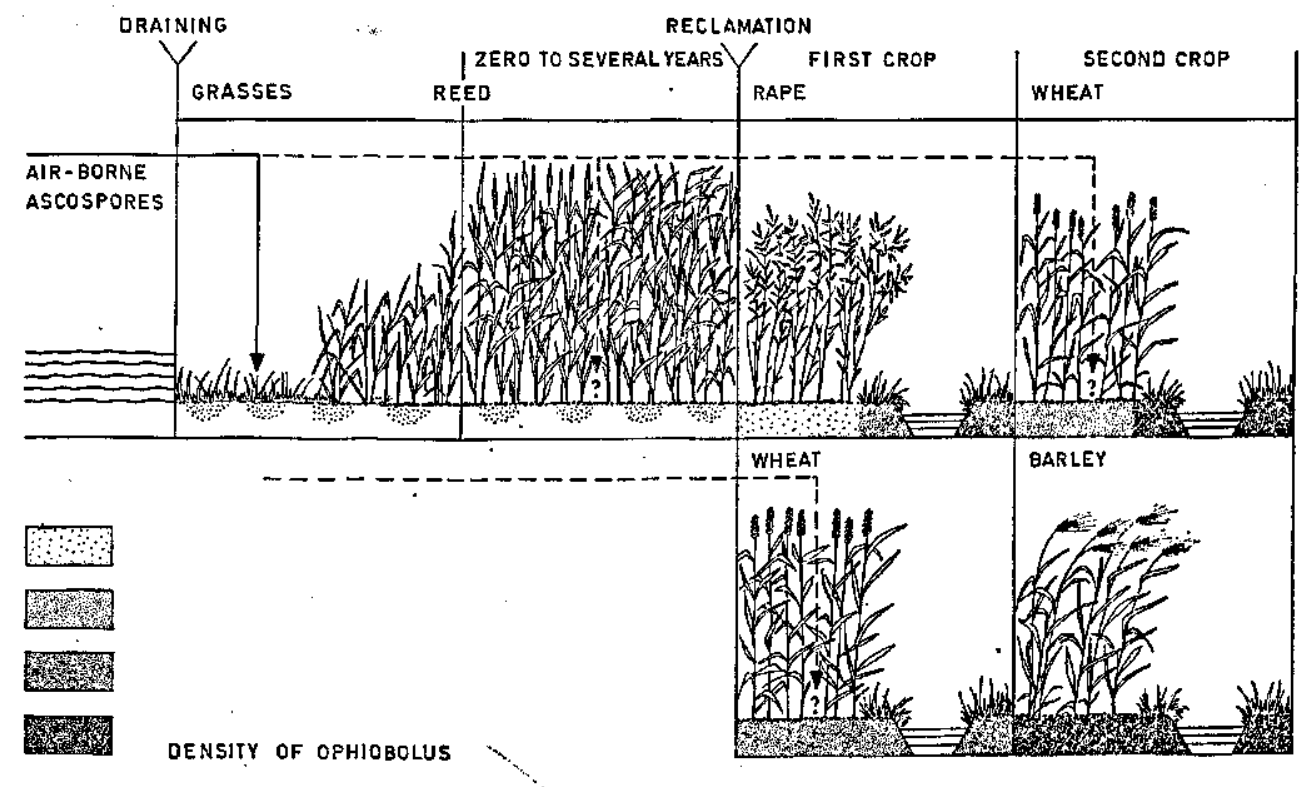

Fig. 7. Scheme of the introduction and spread of Ophiobolus in the Ysselmeer Polders. The top line represents a normal crop rotation; beneath is an experimental one (see text).

opportunity for Ophiobolus to survive (fig. 7). The scarcity of Ophiobolus at particular sites (table 3: A and B section, U 57, U 70) may be related to special circumstances shortly after drainage. For instance, A and B section were too wet for germination of the reed sown in 1958, so that it had to be resown in 1959. There was then less grass than in other parts of the polder the year before. This might explain the fewer foci of Ophiobolus.

In evolution the infectiousness of the ascospores to grasses would favour spread of the fungus to virgin soil, where weed grasses grow but cereals do not. Thus the worldwide distribution of Ophiobolus would be easier to explain. The rapid spread of Ophiobolus through grass in the polder shows the pioneer character of Ophiobolus. On the verges of roads in East Flevoland with a closed grass mat, almost all the grass carried Ophiobolus. SPRAGUE \& LAWRENCE (1959) also showed that Ophiobolus specially pioneered deglaciated terrain, decreasing in importance the longer the soil had been free from ice. Ophiobolus was abundant on grasses sown on soil disinfected with methylbromide (Goss \& GouLd, 1967) and on cut-away peat (O'RouRKE, 1967). Its pioneer character is also well known from Australia both at the beginning of this century and in recent times (ANONYMUS, 1966; GARRETT, 1933-4). The same is known from France (Lemalre \& Jouan, 1966; Ponchet \& Coppenet, 1957). Since 'newly reclaimed soils' has a different meaning in Australia and France from in the polders, Ophiobolus may have been present already on grasses before the soil was farmed, or may be transported with small soil particles by wind (OGILviE \& THORPE, 1962). But its general occurrence suggests that many infections were by ascospores. Perhaps a 
developing and therefore 'incomplete' soil microflora, not yet adapted to new soil conditions, allows ascospore infections more often than assumed up to now. 


\section{5 'Decline' of Ophiobolus}

\subsection{The decline phenomenon}

Growing the same crop for some years in succession usually causes sharp increases in certain soil pathogens and in the incidence of disease. When growing the same crop is continued, two situations can occur. First: the inoculum level of the parasite remains high, and every year the disease causes variably high losses, e.g. potato sickness caused by Heterodera rostochiensis. Second: the disease incidence is reduced after one or a few peak years, and the pathogen decreases considerably. This phenomenon is indicated as decline.

Decline is well known for Ophiobolus in wheat and barley. In 1934 Fellows \& FICKE reported patches of wheat attacked by Ophiobolus to disperse from the centre in succeeding years, whereas the centre itself almost recovered. GLYNNE (1935) mentioned decline of Ophiobolus after attack of more than $35 \%$ of the wheat plants or more than $10 \%$ of barley plants. Bosma $(1946,1962)$ reported the sudden introduction of Ophiobolus into the Dutch Ysselmeer Polders, followed by heavy attack on cereals in the second to fourth years of continuous cultivation, after which Ophiobolus declined. In recent years decline of take-all has become a regular paragraph in the Annual Reports of Rothamsted Experimental Station.

KLAPP (1958) considers decline a normal phenomenon of soil diseases when monoculture continues for a long time. A survey of literature confirms this statement. In 1931 MCNAMARA, HOOTON \& PORTER reported patches of cotton heavily attacked by Phymatotrichum omnivorum to persist only for a few years, then to disappear, and to reappear some years later. MeNZIEs (1959) demonstrated a sharp decline of potato scab, caused by Streptomyces scabies, with continuous potato growing. WeINHOLD et al. (1964) found the same, though less pronounced. Data in the paper of MAURER \& BAKER (1965) show decline also to occur with bean root rot, caused by Fusarium solani $\mathrm{f}$. phaseoli. GLYNNE (1965) mentioned a slight decline in Cercosporella herpotrichoides, causing eyespot of wheat.

Decline of Ophiobolus is a usual occurrence on experimental fields in the Ysselmeer Polders. The phenomenon on these 'young' soils is pronounced, much more than for instance at Rothamsted Experimental Station (A. Reps Rothamsted exp. Stn since 1958; SLOPE, 1967).

Decline of Ophiobolus will now be demonstrated with data from field and greenhouse trials. Effects will be described of Ophiobolus in the initiation of decline, and of break-crops between crops of wheat and barley on the persistence of decline. There- 
after an analysis of the backgrounds of the decline phenomenon will be presented.

The term antagonistic soil will be used to indicate soil which can cause decline of Ophiobolus.

\subsection{Demonstration of decline}

\subsubsection{Observations on decline in the North-East Polder}

In the North-East Polder, which was drained in 1942, a crop rotation experiment was started in 1944 on the Lovinkhoeve Experimental Farm. This farm is situated on a loam soil $(20 \%<2 \mu)$. OHNESORGE (1966) gives some data about the experimental crop rotation.

From 1944 to 1961 the rotations consisted of 3 groups, differing in the share of cereals in the rotation. Wheat, barley, oats and rye were each grown continuously (treatment a), twice in 3 years (treatment b), or once in 3 years (treatment $c$ ). From 1962 on the design was different. Oats and rye were discontinued; their place was taken by wheat and barley, respectively. Also the share of cereals in the rotation was changed, so that there were four treatments:

I continuous wheat or barley;

II wheat or barley twice in 3 years;

III wheat or barley once in 2 years (alternating);

IV wheat or barley once in 4 years; oats with the same frequency (in alternating years). Since 1962 only the continuous cereal plots were situated on the same sites as before. The other treatments were allotted over the field independent of the previous rotation. For relevant treatments the rotation until and since 1961 is indicated in table 8.

I observed the occurrence of Ophiobolus on wheat plots since 1964. No exact data from previous years were available (but see BosMA, 1962). Little attention was paid to the barley plots.

With one or more years' break between two susceptible crops (treatments III and IV) only a trace of whiteheads was ever found $(\ll 1 \%)$. Data about the occurrence of Ophiobolus in treatments I and II are given in table 8. Only the data from treatment I will be discussed here. For treatment II: see 5.4.1.

Treatment I plot 4 clearly illustrates decline; no whiteheads are found. In treatment I, plot 6, oats had been grown before 1962. In 1964, the third year of continuous wheat growing, this plot was most severely attacked. The complete disappearance of Ophiobolus in 1965 shows that there too decline occurred to a high degree.

\subsubsection{Demonstration of decline in East Flevoland}

The Ysselmeer Polders Development and Settlement Authority planned crop rotation trial OFL 264 to learn about different crop sequences. The trial is on field R 26 on a clay loam $(32 \%<2 \mu)$. In its most extensive form the field consisted of 280 different plots, the total field measuring 24 metres by 300 metres. In 1961, directly 
after reclamation, the trial started with 7 different crops: spring rape, sugar-beet, potatoes, lucerne, spring barley, oats, and spring wheat. In later years flax and peas were included, spring wheat was replaced by winter wheat, and rape, lucerne, sugarbeet and oats were discontinued. In autumn 1965 and 1966 the whole field was sown with wheat so that the 1966 and 1967 crops were wheat only. The wheat was sown on two dates: a normal sowing date (from mid of October to first week of November) and a very early one (September). In spring 1967 half of the field was treated with (2-chloroethyl) trimethylammonium chloride (CCC).

Since 1964 the percentage whiteheads in each plot of winter wheat has been estimated shortly before ripening. Plots were combined which had parallel histories on the one hand of susceptible cereal crops (wheat and barley) and on the other hand of other crops including oats (indicated as non-cereal) (see table 9). In group A all plots were arranged according to increasing number (1-7) of successive wheat crops, preceded by non-cereal crops. Group B is identical to A, except for spring barley being the first cereal crop. Groups $\mathrm{C}$ and $\mathrm{E}$ have a break of one non-cereal crop preceded by one or two successive wheat or barley crops. In group D all cases are recorded with a break of two non-cereal crops preceded by one cereal crop. Within groups C, D, and E the plots are also arranged according to increasing number of wheat crops after the break.

When reading the table downwards for each group and for each year separately one can observe an increase in the percentage whiteheads to a maximum at the second and sometimes the third cereal crop. (The latter especially when barley is the first cereal crop (group B); clearly the influence of barley is midway between that of wheat and a non-cereal crop). After that, attack by Ophiobolus usually drops to a low percentage. This demonstrates the general appearance of the decline phenomenon

Table 8. Demonstration of the decline phenomenon (see text).

\begin{tabular}{|c|c|c|c|c|c|c|c|}
\hline & \multicolumn{3}{|l|}{ Crop rotation } & \multicolumn{4}{|c|}{ Percentage whiteheads } \\
\hline & 1944 to 1961 inclusive & 1962 & 1963 & 1964 & 1965 & 1966 & 1967 \\
\hline \multirow[t]{2}{*}{ treatment } & continuous wheat & $w w$ & sw & 0 & $\mathbf{0}$ & o & $\mathbf{0}$ \\
\hline & continuous oats & ww & sw & 80 & 0 & 0 & 0 \\
\hline treatment II plot 4 & $\begin{array}{l}2 \times \text { wheat; } 1 \times \text { various } \\
\text { crops (per } 3 \text { years) }\end{array}$ & sug & sw & 1 & pot & 0 & 2 \\
\hline plot 6 & $\begin{array}{l}1 \times \text { oats; } 2 \times \text { various } \\
\text { crops (per } 3 \text { years) }\end{array}$ & sug & sw & 20 & pot & + & 30 \\
\hline
\end{tabular}

$+=$ trace of whiteheads

pot $=$ potatoes

sug $=$ sugar-beet

$\mathrm{SW}=$ spring wheat

$w W=$ winter wheat 
with Ophiobolus. Many unpublished experiments of the Ysselmeer Polders Development and Settlement Authority confirm the results reported here (JONKRR, personal communication).

Table 9. Average percentages whiteheads in wheat after different preceding crops (between brackets) from varlous numbers of plots (after oblique stroke).

\begin{tabular}{|c|c|c|c|c|c|c|c|c|c|}
\hline \multirow{2}{*}{\multicolumn{2}{|c|}{$\begin{array}{l}\text { 1964, 4th } \\
\text { cultivation } \\
\text { year, } \\
\text { sowing } \\
29 / 10\end{array}$}} & \multirow{2}{*}{\multicolumn{2}{|c|}{$\begin{array}{l}1965, \text { 5th } \\
\text { cultivation } \\
\text { year, } \\
\text { sowing } \\
22 / 10\end{array}$}} & \multicolumn{3}{|c|}{$\begin{array}{l}1966 \text {, } \\
6 \text { th cultivation year }\end{array}$} & \multicolumn{3}{|c|}{$\begin{array}{l}1967, \\
7 \text { th cultivation year }\end{array}$} \\
\hline & & & & & $\begin{array}{l}\text { sowing } \\
22 / 10\end{array}$ & $\begin{array}{c}\text { sowing } \\
7 / 9\end{array}$ & & $\begin{array}{l}\text { sowing } \\
3 / 11\end{array}$ & $\begin{array}{l}\text { sowing } \\
19 / 9\end{array}$ \\
\hline $\begin{array}{r}A(---) \\
(--w) \\
(-w w) \\
(w w w)\end{array}$ & $\begin{array}{c}0 / 43 \\
21 / 18 \\
3 / 6 \\
5 / 1\end{array}$ & $\begin{array}{l}(----) \\
(---w) \\
(--w w) \\
(-w w w) \\
(w w w w)\end{array}$ & $\begin{array}{l}0 / 24 \\
4 / 41 \\
4 / 18 \\
2 / 6 \\
0 / 1\end{array}$ & $\begin{array}{l}(----) \\
(---w) \\
(---w w) \\
(--w w w) \\
(-w w w w) \\
(w w w w w)\end{array}$ & $\begin{array}{l}0 / 3 \\
1 / 9 \\
0 / 22 \\
1 / 10 \\
0 / 4\end{array}$ & $\begin{array}{c}7 / 3 \\
30 / 15 \\
26 / 19 \\
17 / 8 \\
15 / 2 \\
5 / 1\end{array}$ & $\begin{array}{l}(---w) \\
(---w w) \\
(---w w w) \\
(--w w w w) \\
(-w w w w w) \\
(w w w w w w)\end{array}$ & $\begin{array}{l}14 / 6 \\
5 / 18 \\
1 / 26 \\
1 / 11 \\
0 / 3\end{array}$ & $\begin{array}{l}63 / 6 \\
21 / 15 \\
12 / 7 \\
7 / 3 \\
20 / 1\end{array}$ \\
\hline $\begin{array}{r}(--b) \\
(-b w) \\
(b w w)\end{array}$ & $\begin{array}{r}2 / 5 \\
19 / 6 \\
10 / 1\end{array}$ & $\begin{array}{l}(---b) \\
(--b w) \\
(-b w w) \\
(b w w w)\end{array}$ & $\begin{array}{l}2 / 2 \\
4 / 4 \\
2 / 6 \\
0 / 1\end{array}$ & $\begin{array}{l}(--b w) \\
(--b w w) \\
(-b w w w) \\
(b w w w w)\end{array}$ & $\begin{array}{l}2 / 1 \\
5 / 1 \\
0 / 4 \\
0 / 1 \\
\end{array}$ & $\begin{array}{l}60 / 1 \\
22 / 3 \\
10 / 2\end{array}$ & $\begin{array}{l}(--b w w) \\
(--b w w w) \\
(-b w w w w) \\
(b w w w w w)\end{array}$ & $\begin{array}{r}1 / 2 \\
13 / 2 \\
1 / 4\end{array}$ & $\begin{array}{r}23 / 2 \\
5 / 2 \\
1 / 1\end{array}$ \\
\hline $\begin{array}{r}(-c-) \\
(c-w)\end{array}$ & $\begin{array}{r}0 / 30 \\
31 / 10\end{array}$ & $\begin{array}{l}(a-c-) \\
(-c-w) \\
(c-w w)\end{array}$ & $\begin{array}{l}0 / 26 \\
3 / 28 \\
4 / 9\end{array}$ & $\begin{array}{l}(a-c-) \\
(a-c-w) \\
(-c-w w) \\
(c-w w w)\end{array}$ & $\begin{array}{l}0 / 6 \\
5 / 11 \\
1 / 20 \\
1 / 5\end{array}$ & $\begin{array}{c}3 / 4 \\
19 / 15 \\
13 / 8 \\
7 / 4\end{array}$ & $\begin{array}{l}(a-c-w) \\
(a-c-w w) \\
(-c-w w w) \\
(c-w w w w)\end{array}$ & $\begin{array}{l}12 / 6 \\
5 / 8 \\
1 / 16 \\
0 / 2\end{array}$ & $\begin{array}{l}40 / 4 \\
26 / 18 \\
13 / 12 \\
16 / 7\end{array}$ \\
\hline$D(c--)$ & $0 / 20$ & $\begin{array}{l}(-c--) \\
(c--w)\end{array}$ & $\begin{array}{l}0 / 33 \\
3 / 19\end{array}$ & $\begin{array}{l}(a-c--) \\
(-c--w) \\
(c--w w)\end{array}$ & $\begin{array}{l}0 / 9 \\
5 / 24 \\
1 / 9\end{array}$ & $\begin{array}{l}3 / 6 \\
21 / 9 \\
12 / 10\end{array}$ & $\begin{array}{l}(a-c--w) \\
(-c--w w) \\
(c--w w w)\end{array}$ & $\begin{array}{c}22 / 5 \\
11 / 15 \\
4 / 6\end{array}$ & $\begin{array}{l}61 / 10 \\
37 / 18 \\
20 / 13\end{array}$ \\
\hline$E(c c-)$ & $0 / 8$ & $\begin{array}{l}(-c c-) \\
(c c-w)\end{array}$ & $\begin{array}{l}0 / 8 \\
2 / 18\end{array}$ & $\begin{array}{l}(a-c c-) \\
(-c c-w) \\
(c c-w w)\end{array}$ & $\begin{array}{l}0 / 2 \\
4 / 8 \\
0 / 4\end{array}$ & $\begin{array}{l}2 / 2 \\
9 / 4\end{array}$ & $\begin{array}{l}(a-c c-w) \\
(-c c-w w) \\
(c c-w w w)\end{array}$ & $8 / 4$ & $\begin{array}{r}45 / 4 \\
25 / 4 \\
6 / 8\end{array}$ \\
\hline
\end{tabular}

$\mathrm{w}=$ wheat; $\mathrm{b}=$ barley; $\mathrm{c}=$ cereals (wheat or barley); $\mathrm{a}=$ any cereal or non-cereal crop; $-=$ non-cereal crops, including oats. E.g. c-ww means: previous crops were two other wheat crops, preceded by one non-cereal crop (which might have been oats, however) and one crop barley or wheat.

To compare the same plots over successive years, the table should be read within groups diagonally from upper left to lower right (with few exceptions). 
After very early sowing the percentage whiteheads is much higher than after sowing at a normal time. Yet, decline occurred there too. Insufficient breakdown of Ophiobolus on infested stubble and roots during the short fallow might be responsible for the severe attack. Further details will be dealt with in 8.2.1.

In 1967 the percentages whiteheads are generally much higher than in previous years. This will be due to the excessive drought during ripening, leading to whiteheads even with mild infections of the roots. Even eyespot-attacked plants suffered from whiteheads that year, and complicated the estimation of percentage Ophiobolus whiteheads. The CCC treatment also increased the percentage whiteheads, confirming the observations of CUNNINGHAM (1967).

The coincidence between percentages whiteheads in groups $C$ and $D$ proves a one-year break between two susceptible crops to be as effective as two years to clear foci of Ophiobolus. After a break, the build-up of Ophiobolus has to start again.

\subsubsection{Reproduction of decline in the greenhouse}

For a more exact study of decline, it was important to know if it could be reproduced under greenhouse conditions. Trials were carried out in which the growth cycle was curtailed to the most active period of plant growth, so that four crops per year could be grown in sequence. The next trial attempted to reproduce decline under such conditions.

Scheme of the experiment Four soils were used, M 70, Q 107 (subsoil clay), S 6, and Valthermond (table 1). These soils were used for four cycles. In the first cycle 3 Mitscherlich pots with each soil were given one of the six following treatments: LO, DO and NO; sown with wheat (indicated by w);

LO, DO and NO; fallow (indicated by $f$ ).

After each cycle one of the pots of each treatment was continued on treatment LOw, whereas the rest of the pots remained on the previous treatment. Sometimes another crop sequence was used. Thus the fourth cycle consisted exclusively of treatment LOw (see table 10).

Results The results of the experiment, measured by the disease indexes at 4 and 8 weeks after sowing, are given in table 10. Addition of Ophiobolus (LOw) for the first time always caused a severe attack. Addition of LO for the second time caused a milder attack. This time a difference between soils was observed. With $M 70$ and Valthermond soils, antagonism was fully established after one LO cycle; with S 6 soil and Q 107 subsoil clay, two LO cycles are needed. The time needed to establish antagonism is correlated with the time the soils have been cropped. Many other trials confirmed that antagonism appeared within 3 to 6 months. During this time antagonism gradually increases.

To learn more about the effect of previous LO, DO or NO treatments on the disease indexes of Ophiobolus-inoculated wheat the results for the different soils and rotations 
Table 10. Effect of various additives, and wheat growing or fallow on severity of disease. Disease indexes assessed at 4 and 8 weeks after sowing (see text).

\begin{tabular}{|c|c|c|c|c|c|c|c|c|c|c|c|}
\hline \multicolumn{4}{|c|}{ Rotation } & \multicolumn{8}{|c|}{ Valthermond soil } \\
\hline \multicolumn{4}{|c|}{ cycle } & \multicolumn{8}{|c|}{ cycle } \\
\hline \multirow[t]{3}{*}{ 1st } & \multirow[t]{3}{*}{ 2nd } & \multirow[t]{3}{*}{ 3rd } & \multirow[t]{3}{*}{ 4th } & \multicolumn{2}{|c|}{ 1st } & \multicolumn{2}{|l|}{ 2nd } & \multicolumn{2}{|c|}{3 rd } & \multicolumn{2}{|l|}{ 4th } \\
\hline & & & & \multicolumn{6}{|c|}{ date of estimating disease index (weeks) } & & \\
\hline & & & & 4 & 8 & 4 & 8 & 4 & 8 & 4 & 8 \\
\hline LOw & LOw & LOw & LOW & 4 & 4.5 & 0 & 0 & $\mathbf{0}$ & 0 & 0 & $\mathbf{0}$ \\
\hline LOf & LOw & LOw & LOw & & & 0.5 & $\mathbf{0}$ & 0 & $\mathbf{0}$ & $\mathbf{0}$ & $\mathbf{0}$ \\
\hline LOf & Lof & LOw & LOw & & & & & 0 & 0 & 0 & $\mathbf{0}$ \\
\hline LOf & Lof & LOf & LOw & & & & & & & 0 & 0 \\
\hline Dof & LOw & LOw & LOw & & & 1 & 3 & 0 & 0 & 0 & 0 \\
\hline NOf & LOw & LOw & LOw & & & 2 & 3 & 0 & 0 & 0 & 0 \\
\hline DOw & LOw & LOw & LOw & 0 & 0 & 0 & 1.5 & 0 & 0 & 0 & 0.5 \\
\hline NOw & LOW & LOw & LOw & 0 & 0 & 1 & 3 & 0 & 0 & 0 & 0 \\
\hline DOf & Dof & LOw & LOW & & & & & 0.5 & 3 & 0.5 & 0 \\
\hline NOf & NOf & LOw & LOw & & & & & 2 & 3.5 & 0 & 0 \\
\hline DOw & DOw & LOw & LOW & 0 & 0 & 0 & 0 & 0 & 0 & 0 & 0 \\
\hline NOw & NOw & LOw & LOW & 0 & 0 & 0 & 0 & 1 & 2.5 & 0 & 0 \\
\hline DOf & DOf & DOw & LOw & & & & & 0 & 0 & 0 & 1 \\
\hline NOf & NOf & NOw & LOw & & & & & 0 & 0 & 0.5 & 1 \\
\hline NOw & NOw & NOw & LOw & 0 & 0 & 0 & 0 & 0 & 0 & 0 & 1.5 \\
\hline LOw & DOw & LOw & LOw & 4 & 4 & 0 & 0 & 0 & 0 & 0 & 0 \\
\hline LOw & NOw & LOW & LOw & 4 & 4.5 & 0 & 0 & 0 & 0 & 0 & 0 \\
\hline DOw & LOw & Dof & LOw & 0 & 0 & 0 & 1 & & & 0 & 0 \\
\hline
\end{tabular}

$0=$ healthy crop; $5=$ dead crop.

LO $=$ Ophiobolus inoculum: DO $=$ sterilized Ophiobolus inoculum; NO $=$ control (no amendment). $w=$ wheat; $f=$ fallow.

1 spontaneous infection.

are combined in table 11. A previous $L O$ treatment caused milder attack than previous DO or NO treatments, whereas virtually no difference could be found between DO and NO.

Build-up of antagonism was alike in treatments LOW and LOf. This means that Ophiobolus alone induces antagonism irrespective of whether wheat has been grown. For DO and NO, in contrast to LO, wheat differs from fallow. This is clearly illustrated when totalling the disease indexes of relevant treatments of table 10 (table 12). For a possible explanation, see discussion (5.2.4).

The higher disease index after a first LO addition in the first cycle than in any other cycle is discussed in 5.2.4. The generally milder attacks in the fourth cycle can be explained by partial loss of virulence of the Ophiobolus strain used. 
Table 10. (continued)

\begin{tabular}{|c|c|c|c|c|c|c|c|c|c|c|c|}
\hline & Rota & & & & & & & soil & & & \\
\hline & & & & & & & & & & & \\
\hline 1 st & 2nd & $3 r d$ & 4th & 1st & & 2nd & & $3 \mathrm{rd}$ & & 4th & \\
\hline & & & & $\overline{\text { date }}$ & f es & $\overline{\text { dise }}$ & ind & weeks & & & \\
\hline & & & & 4 & 8 & 4 & 8 & 4 & 8 & 4 & 8 \\
\hline LOW & LOW & LOw & LOw & 4.5 & 5 & 0 & 0.5 & 0 . & 0 & 0 & 0 \\
\hline LOf & LOw & LOw & LOw & & & 1 & 0.5 & 1 & 0.5 & 0 & 0 \\
\hline LOf & LOf & LOw & LOw & & & & & 0 & 0 & 0 & 0 \\
\hline LOf & Lof & LOf & LOw & & & & & & & 0 & 0 \\
\hline Dof & LOw & LOw & LOw & & & 3 & 4 & 1 & 1 & 1. & 0.5 \\
\hline NOf & LOw & LOw & LOw & & & 2 & 4.5 & 0 & 0 & 0.5 & 0.5 \\
\hline DOw & LOw & LOw & LOw & 0 & 0 & 1 & 2 & 0 & 0 & 1 & 1 \\
\hline NOw & LOw & LOw & LOw & 0 & 0 & 2.5 & 2 & 1 & 1 & 0.5 & 0.5 \\
\hline Dof & DOf & LOw & LOw & & & & & 1.5 & 3 & 0.5 & 1 \\
\hline NOf & Nof & LOw & LOw & & & & & 2 & 4 & 1 & 3 \\
\hline DOw & DOw & LOw & LOw & o & 0 & 0 & 0 & 0 & 0 & 0 & 2 \\
\hline NOw & NOw & LOw & LOw & 0 & 0 & 0 & 0 & 1 & 1 & 0 & 1 \\
\hline DOF & Dof & DOw & LOw & & & & & 0 & 0 & 2 & 3.5 \\
\hline Nof & NOf & NOw & LOw & & & & & 0 & 0 & 2 & 3 \\
\hline NOw & NOw & NOw & LOw & 0 & 0 & 0 & 0 & 0 & 0 & 1 & 1 \\
\hline LOw & DOw & LOW & LOw & 4.5 & 5 & 0 & 0 & 0 & 0 & 0 & 0 \\
\hline LOw & NOw & LOw & LOw & 4.5 & 5 & 0 & 0 & 0 & 0 & 0 & 0 \\
\hline DOw & LOw & DOf & LOw & 0 & 0 & 0 & 2 & & & 0.5 & 2 \\
\hline
\end{tabular}

With Q 107 subsoil clay, spontaneous infection occurred in one pot in the third cycle. The influence of spontaneous infections upon results of the next cycle would be expected to be small, since the amount of Ophiobolus in the soil through such an infection is much smaller than from a LO treatment. The occurrence of spontaneous infection has been discussed in 4.4.

Many other trials with different loam and clay loam soils confirmed the results of this trial. With two or more successive LO treatments, antagonistic soil was obtained which could be used for further research.

\subsubsection{Discussion: general and specific antagonism}

The results of the greenhouse experiments accord with observations from the polders. It is therefore likely that the same process is operating. Since in the greenhouse four cycles run in one year and fresh LO is added each time, the greenhouse-created 
Table 10. (continued)

\begin{tabular}{|c|c|c|c|c|c|c|c|c|c|c|c|}
\hline \multicolumn{4}{|c|}{ Rotation } & \multicolumn{8}{|c|}{ S 6 soil } \\
\hline \multicolumn{4}{|c|}{ cycle } & \multicolumn{8}{|c|}{ cycle } \\
\hline \multirow[t]{3}{*}{ 1st } & \multirow{3}{*}{ 2nd } & \multirow[t]{3}{*}{3 rd } & \multirow[t]{3}{*}{ 4th } & 1st & & \multicolumn{2}{|c|}{ 2nd } & \multicolumn{2}{|c|}{3 rd } & \multicolumn{2}{|c|}{ 4th } \\
\hline & & & & \multicolumn{6}{|c|}{$\overline{\text { date of estimating disease index (weeks) }}$} & & \\
\hline & & & & 4 & 8 & 4 & 8 & 4 & 8 & 4 & 8 \\
\hline LOw & LOw & LOw & LOw & 4.5 & 5 & 3 & 2.5 & 0 & 0 & 0 & 0 \\
\hline LOf & LOw & LOw & LOw & & & 1.5 & 2.5 & 0 & 0 & 0 & 0 \\
\hline Lof & LOf & LOw & LOw & & & & & $\mathbf{0}$ & $\mathbf{0}$ & 0 & $\mathbf{0}$ \\
\hline Lof & LOf & LOf & LOw & & & & & & & 1 & 0 \\
\hline Dof & LOw & LOw & LOw & & & 3 & 4 & 1.5 & 2.5 & 0 & 0.5 \\
\hline NOf & LOw & LOw & LOw & & & 3 & 5 & 2.5 & 2 & 0 & 0.5 \\
\hline DOw & LOw & LOw & LOw & 0 & 0 & 3 & 3.5 & 0.5 & 2 & 0 & 0 \\
\hline NOw & LOw & LOw & LOw & 0 & 0 & 1.5 & 2.5 & 1 & 1 & 1 & 2 \\
\hline DOf & DOf & LOw & LOw & & & & & 0.5 & 3.5 & 0 & 1.5 \\
\hline NOf & NOf & LOw & LOw & & & & & 2 & 4.5 & 0 & 1 \\
\hline DOw & DOw & LOw & LOw & 0 & 0 & 0 & 0 & 1.5 & 4 & 0 & 1 \\
\hline NOw & NOW & LOw & LOW & 0 & 0 & 0 & 0 & 2 & 4.5 & 0 & 2.5 \\
\hline DOF & DOf & DOw & LOw & & & & & $\mathbf{0}$ & 0 & 1 & 3.5 \\
\hline NOf & NOf & NOw & LOw & & & & & 0 & 0 & 2 & 4 \\
\hline NOw & NOw & NOw & LOw & 0 & 0 & 0 & 0 & 0 & 0 & 1 & 1.5 \\
\hline LOw & DOw & LOw & LOw & 4.5 & 5 & 0.5 & 0.5 & 0 & 0 & 0 & 0 \\
\hline LOW & NOw & LOw & LOw & 4.5 & 5 & 0.5 & 0.5 & 0 & 0 & 0 & 0 \\
\hline DOw & LOw & Dof & LOw & 0 & 0 & 2 & 4 & & & 0 & 0.5 \\
\hline
\end{tabular}

Table 11. Effect of different additives in previous cycles on severity of disease in Ophiobolus-inoculated wheat. Average disease indexes on four soils (derived from table 10).

\begin{tabular}{|c|c|c|c|c|c|c|}
\hline \multirow[t]{2}{*}{ Previous treatment } & \multicolumn{6}{|c|}{ Cycle } \\
\hline & \multicolumn{2}{|l|}{ 2nd } & \multicolumn{2}{|l|}{$3 \mathrm{rd}$} & \multicolumn{2}{|l|}{ 4th } \\
\hline & \multicolumn{6}{|c|}{ date of disease assessment (weeks) } \\
\hline & 4 & 8 & 4 & 8 & 4 & 8 \\
\hline Lo & $1.0(6)$ & $1.0(6)$ & 1.2 (16) & $1.5(16)$ & $0.1(19)$ & $0.8(16)$ \\
\hline LO/LO & & & $0.4(12)$ & $0.3(12)$ & $0.3(16)$ & $0.4(16)$ \\
\hline LO/LO/LO & & & & & $0.1(16)$ & $0.0(16)$ \\
\hline DO & $1.4(9)$ & $2.8(9)$ & $1.0(8)$ & $2.5(8)$ & 1.1 (4) & $2.5(4)$ \\
\hline No & $2.0(6)$ & $3.3(6)$ & $2.0(8)$ & $3.3(8)$ & $1.2(8)$ & $1.9(8)$ \\
\hline
\end{tabular}

Figures in brackets indicate the number of pots. 
Table 10. (continued)

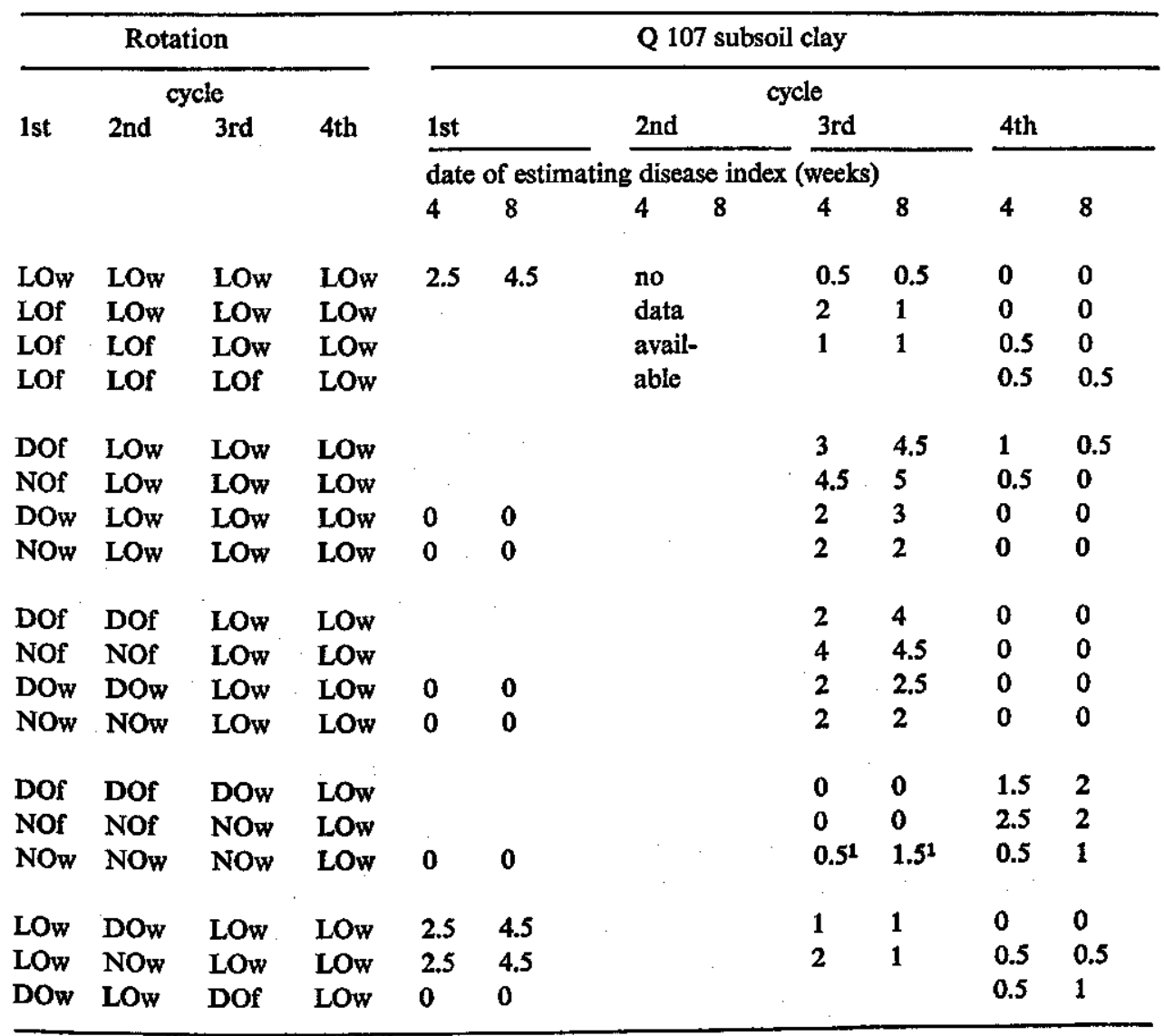

Table 12. Effect of wheat growing or fallow, combined with DO or NO, in the previous cycle on severity of disease in Ophiobolus-inoculated wheat. Average disease indexes on four soils (derived from table 10).

\begin{tabular}{|c|c|c|c|c|c|c|}
\hline \multirow{3}{*}{$\begin{array}{c}\text { Previous treatment } \\
\qquad \\
\end{array}$} & \multicolumn{6}{|c|}{ Cycle } \\
\hline & \multicolumn{2}{|l|}{ 2nd } & \multicolumn{2}{|l|}{$3 r d$} & \multicolumn{2}{|l|}{$4 \operatorname{th}^{2}$} \\
\hline & \multicolumn{4}{|c|}{ date of disease assessment (weeks) } & & \\
\hline & 4 & 8 & 4 & 8 & 4 & 8 \\
\hline $\begin{array}{l}\text { wheat }(+D O \text { or } N O) \\
\text { fallow }(+D O \text { or } N O)\end{array}$ & $\begin{array}{l}1.2(9) \\
2.3(6)\end{array}$ & $\begin{array}{l}2.4(9) \\
3.9(6)\end{array}$ & $\begin{array}{l}1.2(8) \\
1.8(8)\end{array}$ & $\begin{array}{l}2.1(8) \\
3.8(8)\end{array}$ & $\begin{array}{l}0.6(4) \\
1.4(8)\end{array}$ & $\begin{array}{l}1.3(4) \\
2.5(8)\end{array}$ \\
\hline
\end{tabular}

Figures in brackets indicate the number of pots.

1 In the fourth cycle the previous treatments have been wheat/wheat or fallow/wheat instead of wheat or fallow, respectively. 
antagonism can be expected to be much more pronounced than the one occurring in the field.

The presence of Ophiobolus in its saprophytic phase (LO) seems to induce an antagonism (also) active against Ophiobolus in its parasitic phase. Though the decline mechanism will be further evaluated later on (from chapter 6), it is already necessary to point to the role of micro-organisms in general as antagonists of Ophiobolus. This fact is well known from literature. Several authors have found that fungi and bacteria generally reduce the severity of disease when they are introduced into the soil simultaneously with Ophiobolus (BROADFOOT, 1933a; BRÖMMBLHUES, 1935; FLÜCK, 1955; Lal, 1939; SANFord \& Broadfoot, 1931; Siegle, 1961; SlaGg \& Fellows, 1947; ZoGG, 1950; ZoGG, 1951). GARRETT (1933-4) found a negative correlation between the number of bacteria in soils and the severity of Ophiobolus attack, though there were exceptions (GARRETT, 1936). Thus in a normal soil Ophiobolus will never show its full capacity. This type of antagonism to Ophiobolus is not specific.

But in the greenhouse trial LO treatment induced an antagonism which was not induced by NO treatment or by adding organic material (DO), and which much better protected the plants against Ophiobolus than the antagonism normally present in each soil. This antagonism can, therefore, be considered specific. The slower build-up of specific antagonism in less ripe soils is strong evidence that micro-organisms may contribute to it. In this way it is like non-specific antagonism. The difference between the two types of antagonism can be illustrated with some of the phenomena observed in the experiment of 5.2.3.

Disease indexes with first $\mathrm{LO}$ treatment are highest in the first cycle. This might be caused by decreased microbial activity in the soil at the start of the experiment, since the soil samples were collected at the end of the winter and stored at $4^{\circ} \mathrm{C}$ for some weeks. Higher microbial activity may explain why there is less disease with LO treatment after wheat with DO or NO treatments than after fallow. This effect is not apparent when the previous treatment is LO, since the specific antagonism induced by Ophiobolus will overshadow the general microbial activity. Moreover, most wheat plants are killed very early when LO is first introduced, so that the real difference between wheat growing and fallow is very small.

Thus the disease is slightly moderated by the non-specific action of the general soil microflora and is sharply attenuated by the specific change in the microflora induced by the previous presence of Ophiobolus. This is illustrated in the as yet hypothetical scheme of figure 8 . More evidence will be presented in later chapters. The term reduction will be used for the effect of the general soil microflora upon the severity of Ophiobolus attack. The reduction is caused by the general antagonism found in every normal soil. The term decline will be reserved for the specific attenuation in disease induced by previous presence of Ophiobolus. Decline is caused by specific antagonism. Hereafter antagonism without further epithet will refer to the specific antagonism studied here. The non-specific antagonism will always be indicated as such ('general antagonism').

TYNER (1940) grew wheat continuously in a greenhouse as in my trial, except that 
he only inoculated at the start of the first cycle. His results agree with mine in that the disease was severe only in the first cycle. The other pathogens with which he worked, Fusarium culmorum and Helminthosporium sativum, behaved the same. Thus again decline is not limited to one pathogen. BROADFOOT (1933a) also found unexpectedly healthy plants when wheat was grown after a previous heavily diseased crop. He explained it by assuming a decrease in virulence of Ophiobolus. ANGell (1945) related the alternating high and low disease indexes after inoculation at the start of the first cycle only to availability of plant nutrients. When wheat was heavily attacked little nutrients was used and next crop thus had plenty, resulting in healthy plants. Indeed ample fertilization does largely suppress disease caused by Ophiobolus (e.g. Clark, 1942; Cunningham, 1966), but my trials proved other factors to predominate.

BockMann (1955) and Ponchet \& COPPENET (1957) have repeatedly inoculated soil with Ophiobolus in successive cycles. Their figures show that antagonism to Ophiobolus approached a maximum within 2 to 4 cycles, according to soil. Even a soil, notorious for heavy attack of Ophiobolus could reach a high degree of antagonism. The Valthermond soil in my trial behaved in the same way. This type of soil, sandy, rich in humus, was known to suffer badly from Ophiobolus. Yet it proved to be very antagonistic after one or more LO treatments. Various types of soil differed only slightly in the development of antagonism.

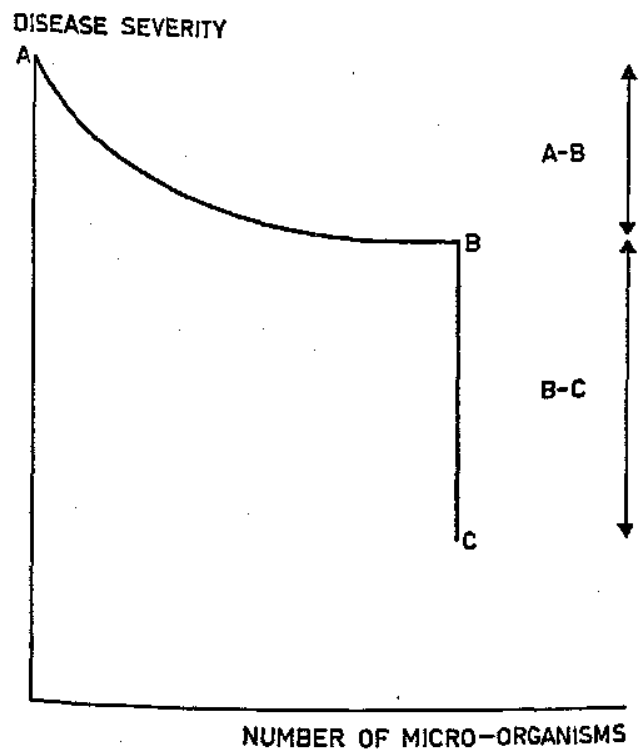

Fig. 8. Relation between the number of micro-organisms per unit soil and severity of Ophiobolus attack; both on arbitrary scales.

$A-B=$ reduction of severity with increased number of micro-organisms.

$B-C=$ fall in severity with a qualitative change in the microflora (decline). 


\subsection{Specificity of Ophiobolus in inducing decline}

Large quantities of Ophiobolus inoculum induce antagonism. The specificity of this relation needs study. The trial described in 5.2.3 already indicates that the medium does not interfere to any appreciable degree with the antagonism. I now studied whether an avirulent strain of Ophiobolus also induces antagonism and whether other fungi, introduced into the soil, induce antagonism to Ophiobolus.

\subsubsection{Does an avirulent strain of Ophiobolus induce antagonism?}

A strain of Ophiobolus cultured for a long time on PDA had lost most of its virulence. It was used to prepare inoculum in the usual way, indicated as LO(lv) (low virulence). Groups of 8 pots with $T 69$ soil, 4 of each sown with wheat and $4 \mathrm{kept}$ fallow, were treated with LO, LO(lv), DO and NO. Only LO induced disease with an average disease index 3.12 months after sowing. In a second cycle all pots were inoculated with LO and sown with wheat. The average disease indexes of the 4 pots of each treatment are given in table 13. No difference exists between the disease indexes after LO(lv), DO or NO treatment; only LO induced antagonism. The Ophiobolus strain had to be virulent to initiate antagonism.

The higher disease indexes after fallow in the first cycle, especially after LO treatment, than after wheat contradict the results of the experiment of 5.2.3, where LO treatment had the same effect after a wheat crop as after fallow.

\subsubsection{Do other fungi induce antagonism to Ophiobolus?}

Other soil fungi tested for their capacity to induce antagonism to Ophiobolus were cellulolytic, thus similar in food preference to Ophiobolus: Helminthosporium sativum, a wheat pathogen isolated from barley seed, and Gliocladium roseum and Chaetomium sp., both saprophytes, isolated from the soil. Fusarium spp. were not tested because there is always so much of them under continuous cereal growing, apparently without inducing antagonism to Ophiobolus (5.2.3), that they can safely be assumed to be ineffective.

Table 13. Effect of virulence of Ophiobolus on the development of decline. Disease indexes of Ophiobolusinoculated wheat after different treatments in the previous cycle.

\begin{tabular}{lll}
\hline & Wheat & Fallow \\
LO & & \\
LO $(\mathrm{lv})^{1}$ & 1.5 & 3.0 \\
DO & 4.1 & 4.8 \\
NO & 4.3 & 4.6 \\
\hline
\end{tabular}

$1 \mathrm{lv}=$ low virulence. 
Inoculum of these fungi was prepared in the same way as that of Ophiobolus. It is indicated as LH for H. sativum, LG for G. roseum, and LC for Chaetomium sp. The chloropicrin-killed material is called DH, DG and DC, respectively. Wooden boxes were filled with $U 43$ soil sieved through a gauze of $1 \mathrm{~cm}$ mesh. After applying the various additives the soil was kept fallow for the first cycle of three months. In a second cycle two boxes from each group were treated as in the first cycle, while one was differently treated and sown with wheat. The two were treated differently and sown with wheat in the third cycle. The treatments and disease ratings of the wheat plants are shown in table 14.

In the second cycle antagonism was not yet induced by LOf or by other treatments. In the third cycle antagonism is only found for LOf/LOf/LOw. This illustrates the highly specific induction of antagonism by Ophiobolus only. The disease rating of the third cycle only refers to living plants, two months old. If plants killed by Ophiobolus be also included, the index for LOf/LOf/LOw increases to 1.9 and for all other, except the uninfectious treatments, to 4.8 to 5 . Even then it is evident that only Ophiobolus induces antagonism.

The treatment LHw in the second and third cycle had been included to ascertain that LH did not cause disease which could be mistaken for take-all. Under the prevailing conditions $H$. sativum was not pathogenic.

The trial was repeated with fewer treatments and $\mathrm{T} 69$ soil for three cycles. Wheat

Table 14. Effect of application of different fungt in previous cycles on the establishment of decline (see text).

\begin{tabular}{|c|c|c|c|c|}
\hline \multicolumn{3}{|c|}{ Treatment } & \multicolumn{2}{|c|}{ Disease index } \\
\hline & ycle & & & ycle \\
\hline 1st & 2nd & $3 r d$ & 2nd & 3 rd \\
\hline LOf & LOw & & 4.5 (1) & \\
\hline LCf, LGf, LHf & LOw & & 3.7 (3) & \\
\hline DCF, DGf, DHf, DOf, NOf, & LOw & & $3.9(5)$ & \\
\hline DOf & LHw & & 0 (1) & \\
\hline Nof & NOw & & $0 \quad$ (1) & \\
\hline LOf & Lof & LOw & & $0.3(2)$ \\
\hline LCf, LGf, LHf & LCF, LGf, LHf & LOw & & $4.5(6)$ \\
\hline DCf, DGf, DHf, DOf, NOf & DCf, DGf, DHf, DOf, NOf & LOw & & $4.6(10)$ \\
\hline DOf. & Dof & LHw & & $0 \quad(2)$ \\
\hline Nof & NOf & NOw & & \\
\hline
\end{tabular}

$C=$ Chaetomium

$G=$ Gliocladium

$H=$ Helminthosporium

f $=$ fallow

$\mathrm{w}=$ wheat

Figures in brackets indicate the number of boxes 
was sown in each cycle. Of the five boxes per treatment three were treated alike in the first and second cycles and inoculated with $L O$ in the third cycle; two were inoculated with $\mathrm{LO}$ in the second cycle. The results were the same as in the first trial, though no boxes were fallowed and another soil was used (table 15). For the

Table 15. Effect of application of different fungi in previous cycles on the establishment of decline.

\begin{tabular}{|c|c|c|c|c|c|}
\hline \multicolumn{3}{|c|}{ Treatment } & \multicolumn{3}{|c|}{ Disease index } \\
\hline & cycle & & & cycle & \\
\hline 1st & 2nd & $3 \mathrm{rd}$ & 1st & 2nd & 3 rd \\
\hline LC, LG, LH & LO & & $0(6)$ & $3.8(6)$ & \\
\hline DO, NO & LO & & 0 (4) & 3.9 (4) & \\
\hline LO & LO & LO & $5(5)$ & $1.3(5)$ & $0.2(5)$ \\
\hline LC, LG, LH & LC, LG, LH & LO & 0 (9) & $0.3^{1}(9)$ & $1.7(9)$ \\
\hline DO, NO & DO, NO & LO & $0(6)$ & $0.3^{1}(6)$ & $1.5(6)$ \\
\hline
\end{tabular}

$C=$ Chaetomium

$G=$ Gliocladium

$H=$ Helminthosporium

Figures in brackets indicate the number of boxes

1 spontaneous infection

spontaneous occurrence of Ophiobolus in some boxes in the second cycle, ascospore infection has to be considered (see 4.4 and 5.2.3). In the third cycle the virulence of the inoculum was apparently lower than in the first and the second cycle; inoculation only caused slight infection. The small differences in disease index still showed that other fungi do not induce antagonism to Ophiobolus. In another trial with the same fungi and two cycles of fallow, wheat was sown and inoculated with LO in the third cycle. The results confirmed those of the earlier experiments.

\subsubsection{Discussion}

Antagonism is only induced by a large amount of living virulent Ophiobolus. Three other fungi and an avirulent strain of Ophiobolus were not able to induce antagonism to Ophiobolus. This demonstrates the high specificity of antagonism. Equally it is unlikely that soils antagonistic to Ophiobolus will be antagonistic to other fungi, but this has not been investigated.

\subsection{Eliminating decline with other crops than wheat and barley}

Since antagonism to $O$ phiobolus is induced by $L O$ in the greenhouse and by growing wheat continuously in the field, the antagonism to Ophiobolus may be influenced by: 
1. interruption of LO treatment (in greenhouse trials);

2. interruption of LO treatment and the growing of another crop than wheat (in greenhouse trials); interruption of continuous wheat or barley growing (in the field). The influence of a break-crop might be more than a general action of the actual break; it might be specific for the crop grown. Such a specific influence of different break-crops upon disease severity in the next wheat crop could also be estimated by growing a number of crops as a first crop on fresh soil, before Ophiobolus-inoculated wheat.

\subsubsection{The effect of interruption of LO treatment or continuous cereal growing on decline of Ophiobolus}

Antagonism induced in the greenhouse can be considered an exaggeration of the one in the field. In greenhouse trials LO is added at the start of each cycle, whereas in the field the amount of Ophiobolus is always low after the peak attack. In the field antagonism persists when wheat continues to be grown with so little Ophiobolus on its roots that symptoms hardly appear above ground, but in the greenhouse the effect of a break of LO treatment with continuous wheat growing is uncertain. In the greenhouse the lapse between sowings is three months, only a quarter of that in nature. Allowing for the low activities of chemical and biological systems in winter, the effect of one cycle in the greenhouse may be equivalent to half a cycle in the field.

The average disease indexes of relevant treatments from table $10(5.2 .3)$ at eight weeks after sowing are given in table 16 . Since only LO induces antagonism, DO and NO, and fallow and wheat growing are combined as much as possible. Thus in

Table 16. Preservation of decline with interruption of LO treatment and wheat growing during one cycle. Disease indexes derived from table 10;8 weeks after sowing.

\begin{tabular}{|c|c|c|c|c|c|c|c|c|c|c|c|c|c|}
\hline \multicolumn{4}{|c|}{ Treatment } & \multicolumn{10}{|c|}{ Soil } \\
\hline & & & & Valt & ermon & $1 \mathrm{M} 7$ & & S 6 & & Q 10 & & average & \\
\hline \multicolumn{4}{|c|}{ cycle } & & & & & \multicolumn{2}{|c|}{ cycle } & & & & \\
\hline $1 s t$ & 2nd & $3 r d$ & 4th & 3rd & 4th & 3 rd & 4th & 3 rd & 4th & 3 rd & 4th & $3 \mathrm{rd}$ & 4 th \\
\hline Lo & LO & Lo & LO & 0 & 0 & 0.2 & o & 0 & 0 & 0.8 & 0.1 & $0.3(12)$ & $0 \quad$ (16) \\
\hline Lo & DN1 & Lo & LO & 0 & 0 & 0 & 0 & 0 & 0 & 1.0 & 0.3 & $0.3(8)$ & $0.1(8)$ \\
\hline DN & LO & LO & LO & 0 & 0.1 & 0.5 & 0.6 & 1.9 & 0.8 & 3.6 & 0.1 & $1.5(16)$ & $0.4(16)$ \\
\hline DN & DN & LO & LO & 2.3 & 0 & 2.0 & 1.8 & 4.1 & 1.5 & 3.3 & 0 & $2.9(16)$ & $0.8(16)$ \\
\hline DO & LO & $\mathrm{DO}^{2}$ & LO & & 0 & & 2.0 & & 0.5 & & 1.0 & & 0.9 (4) \\
\hline DN & DN & DN & LO & & 1.2 & & 2.5 & & 3.0 & & 1.7 & & 2.1 (12) \\
\hline
\end{tabular}

$\mathrm{DN}=\mathrm{DO}$ and NO combined.

Figures in brackets indicate the number of pots.

1 wheat growing continued.

2 wheat growing interrupted. 
DN/LO/LO/LO, DN stands for DOf, NOf, DOw and NOw. In LO/DN/LO/LO, $\mathrm{DN}$ in the second cycle represents DO and NO combined with wheat growing since fallow was not applied in this series. In the third cycle of DO/LO/DO/LO, DO represents a combination of $\mathrm{DO}$ with fallow since no wheat was grown here. Neither in $\mathrm{LO} / \mathrm{DN} / \mathrm{LO} / \mathrm{LO}$ nor in $\mathrm{DO} / \mathrm{LO} / \mathrm{DO} / \mathrm{LO}$ is the antagonism reduced by the interruption of LO treatment.

Results from the field trial described in 5.2.1 give some indication about decline in the field when wheat is grown twice in three years (table 8; treatment II). In 1964 the second successive wheat crop had 1 and $20 \%$ whiteheads on plot 4 and 6 , respectively. In 1967 there were 2 and 30\%. It is remarkable that percentage whiteheads is so much lower on plots cropped with wheat two years in three since 1944 than on plots where the cereal crop was oats grown one year in three from 1944 to 1961 . With 2 wheat crops in 3 years antagonism had become established to a rather high degree, and the one-year break only slightly reduced it. Plot 6 illustrates that establishment of decline with this crop rotation takes longer than with continuous wheat growing, since in 1967 the percentages whiteheads are not yet lower than in 1964. The barley plots in the same field trial also showed decline with 2 cereal crops in 3 years.

The influence of interruption of wheat growing has also been the subject of a special trial. Mitscherlich pots were filled with $U 43$ soil sieved through a gauze of $1 \mathrm{~cm}$ mesh. The trial comprised 12 rotations with three replications each. First, antagonism was induced by two cycles of LO treatment of wheat. In the second cycle, disease indexes for all pots still exceeded four. In the third cycle some other crops were grown. No Ophiobolus was added except for one series of three pots with wheat. In the fourth cycle part of the series was again treated with LO and sown with wheat, part was again sown with a break-crop without addition of LO (table 17). The antagonism proved to persist over the break of one cycle, irrespective of the crop (fallow included). Only after oats was there more disease, suggesting elimination of antagonism by this crop. In the fifth cycle the disease was less severe so that differences were too small to be reliable. Yet the highest disease index occurs with NO/NO/ $\mathrm{NO} / \mathrm{NO} / \mathrm{LO}$ and the lowest with $\mathrm{LO} / \mathrm{LO} / \mathrm{LO} / \mathrm{LO} / \mathrm{LO}$. All other treatments gave results between these two extremes, indicating that antagonism is only partially lost even with two break-crops in succession.

5.4.2 Effect of the type of previous crop on severity of disease in wheat inoculated with Ophiobolus

To further test possible specific effects of the crop used as a break-crop, different crops were grown as a first crop on U 43 and T 69 soils before LO-treated wheat. In this way, crops which would harm the soil condition, and possibly stimulate Ophiobolus, could be detected.

Peas, flax, potatoes, oats, wheat and fallow were compared with LO-treated wheat, in five replications on each soil. LO-treated wheat grown after all treatments had 
disease indexes above three, except after wheat inoculated with Ophiobolus, in which case the index was much lower. The results completely agree with findings of BocKMANN (1955). They show, for instance, that growing wheat does not in itself promote Ophiobolus attack of subsequent wheat. This unharmful effect of wheat itself could already be concluded from table 10 but does not agree with results obtained by WELTE \& TROLLDENIER (1963) and ZOGG (1959) who found a decreased capacity to antagonize Ophiobolus in soils which had borne a high proportion of cereal crops.

In the field trial described in 5.2.2 a remarkable prolonged after-effect of flax was observed. Where wheat had been grown for two or more years, percentage whiteheads in 1965-1967 was slightly but consistently higher three years after a crop of flax than after the other crops (table 18). These data show the complexity of the influence of specific crops.

\subsubsection{Discussion}

One of the interesting aspects of the experiments described is the tendency of the antagonism to persist partially over the growing of one break-crop in the field and even two in the greenhouse. Unfortunately, only few data are available about the effect of interruption of continuous wheat in practice. With wheat 2 years and oats 1 year in 3 the second wheat crop always yields very poorly (RouND, 1967). BULLEN (1963-5) even expects continuous winter wheat in Britain to be very risky because of Ophiobolus. This contrasts with continuous barley, which is common in Britain

Table 17. Effect of interruption of continuous wheat growing on the preservation of decline.

\begin{tabular}{|c|c|c|c|c|c|c|c|}
\hline \multirow[b]{3}{*}{ 1st } & \multirow[b]{3}{*}{ 2nd } & \multicolumn{3}{|c|}{ Rotation } & \multicolumn{3}{|c|}{ Disease index of wheat } \\
\hline & & \multicolumn{3}{|l|}{ cycle } & \multicolumn{3}{|c|}{ cycle } \\
\hline & & 3 rd & 4th & 5 th & $3 \mathrm{rd}$ & 4th & 5th \\
\hline LO & LO & LO & LO & Lo & 2.3 & 1.5 & 0.5 \\
\hline LO & LO & No & LO & LO & 0 & 1.2 & 1.1 \\
\hline LO & LO & oats & LO & LO & & 3.2 & 1.6 \\
\hline LO & LO & pot & LO & LO & & 1.5 & 1.0 \\
\hline LO & LO & peas & LO & LO & & 1.0 & 1.0 \\
\hline LO & LO & fall & LO & LO & & 0 & 1.4 \\
\hline NO & No & NO & LO & LO & 0 & 4.3 & 1.6 \\
\hline LO & LO & NO & No & LO & 0 & 0.9 & 1.3 \\
\hline LO & LO & oats & oats & LO & & & 1.5 \\
\hline LO & LO & peas & pot & LO & & & 1.3 \\
\hline LO & LO & fall & fall & LO & & & 1.0 \\
\hline No & NO & No & NO & LO & 0 & $1.8^{1}$ & 2.5 \\
\hline
\end{tabular}

\footnotetext{
1 spontaneous infection

pot $=$ potatoes

fall $=$ fallow
} 
Table 18. Increased incidence of Ophiobolus by growing flax three years before.

\begin{tabular}{|c|c|c|c|c|c|c|}
\hline \multicolumn{4}{|c|}{ Rotation } & \multicolumn{3}{|c|}{ Percentage whiteheads } \\
\hline \multicolumn{4}{|c|}{ time before year of assessment (years) } & & & \\
\hline 3 & 2 & 1 & 0 & 1965 & 1966 & 1967 \\
\hline cereal & any & $\mathbf{w}$ & $\mathbf{w}$ & $2 / 42$ & $10 / 42$ & $20 / 28$ \\
\hline non-cereal & any & $\mathbf{w}$ & $\mathbf{w}$ & $2 / 42$ & $12 / 42$ & $23 / 28$ \\
\hline flax & any & $w$ & w & $6 / 21$ & $15 / 21$ & $30 / 14$ \\
\hline
\end{tabular}

Key: see table 9.

(BOLAM, 1966). According to LESTER \& SHIPTON (1967) antagonism to Ophiobolus generally occurs with continuous barley. Interruption of continuous barley growing with one break-crop is deprecated, because the second crop after the break will yield so little, owing to heavy attack by Ophiobolus, that this more than nullifies the good yield of the first (CONNOLD, 1966; JONES, 1967; SLOPE, 1965; WALKER, 1967).

Another interesting problem is the function of grass or grass-clover mixtures as a break-crop, mostly grown for more than one year. Here the views about them transmitting $O$ phiobolus and possibly preserving the antagonism are contradictory. Whereas some authors state the noteworthy low damage by Ophiobolus after grass (N.B. a carrier!) (BockManN, 1965; BockMANN \& HARTZ, 1965; HeARD, 1965; KoBLeT, 1964; Lewis, Procter \& HoOD, 1960; OGILVIe \& ThORPE, 1962), others mention a high frequency of Ophiobolus in this situation (ADAM, 1951; BUTLER, 1959; CHAMBERS, 1962; SiMS, 1958; TAYLOR, 1966; DE Vos, 1966), specially when lucerne and clover meadows have been overtaken by grasses after some time (GLYNNE, 1963; Louw, 1957).

The induction or preservation of antagonism when grass is grown should not be excluded. ANGell \& MILLS (1951) found equally low root damage in wheat as a fourth crop after 3 years wheat, and after one year wheat plus two years grass, as opposed to wheat after one year wheat plus two years with non-carrier crops or fallow. This agrees with the low incidence of Ophiobolus in the meadow near Kampernieuwstad (table 2).

Generally, continuous cereal cropping will not be advisable since, even without observable disease, yields will always be lower than with normal crop rotations. But economics or management sometimes make continuous cereals attractive.

Finally the influence of one break-crop upon Ophiobolus, interesting as it may be, does not contribute greatly to practical decisions on wheat growing. In many European countries, including the Netherlands, the damage due to Cercosporella herpotrichoides in rotations dominated by cereals is larger than the damage caused by Ophiobolus. Therefore in planning crop rotations, $C$. herpotrichoides has to be considered more than Ophiobolus. 


\section{Indirect methods to establish the microbial origin of decline}

Different hypotheses can be developed to explain the decline of Ophiobolus:

1. Ophiobolus induces a biological antagonism against itself;

2. Ophiobolus poisons its own habitat by producing harmful chemicals (staling effect);

3. Ophiobolus loses its virulence after a heavy attack;

4. plentiful supply of nutrients after a bad harvest (caused by Ophiobolus) will enable next crop better to resist Ophiobolus;

5. after a heavy attack plants die earlier than normal. So they leave less infected material (since plants remain smaller), which is exposed to competitive saprophytism longer than after a light attack. Thus next crop is exposed to a low inoculum level.

The last three hypotheses, of which two were mentioned in 5.2.4, can be rejected immediately, since the design of the experiment described in 5.2.3, in which decline was clearly demonstrated, was such that the factors mentioned in hypotheses 3,4 and 5 could not operate. At the start of each cycle fresh virulent Ophiobolus inoculum was added (hypotheses 3 and 5). In soil which was kept fallow LO induced antagonism and DO did not (hypothesis 4); the amount of fertilizer applied to soil on which wheat had been grown was corrected for the weight of the crop harvested (hypothesis 4).

Of the remaining two hypotheses the first seems to be most probable, since any staling products would be supposed to become degraded very quickly in a microbiologically active medium, such as soil, and therefore to be of minor importance. Microbial antagonism to Ophiobolus might act in different ways, such as competition for nutrients, hyperparasitism, production of antibiotics. In the last case antagonism would have a chemical basis, just like staling. To obtain further information about the mechanism governing decline, a series of trials was set up. They are only partially suitable to discriminate between antagonism and staling. These trials include:

Assessment of the effect of partial sterilization or sterilization of antagonistic soil by chemicals or heat (6.1);

Assessment of the effect of dilution of antagonistic soil with fresh soil (6.2);

Assessment of the antagonistic capacity of soil extracts (6.3).

The conclusion that decline is caused by microbial antagonism is anticipated in the description of the trials to allow a more directed description. 


\subsection{Sterilization and partial sterilization of antagonistic soil by chemicals or heat}

For some decades soil disinfection with chemicals or steam has been common practice, especially in horticulture. Though the biocidal activity of many of the chemicals used is well known, the actual changes in the soil biota have not been studied in detail until recently. Some data about the change in soil microflora through destruction of a proportion of the micro-organisms can be found in many papers as of DOMSCH (1958, 1959, 1960a, 1960b, 1964b), KREUTZER (1963, 1965), REBER (1967a, 1967b) and WELVAERT (1962).

Before starting to describe the trials some general remarks are made about the soil disinfectants used and their effect on soil microbiota.

Among soil disinfectants chloropicrin (CP) is one of the most effective. It has a general activity and is considered a broad-spectrum biocide. Methylbromide (MB) has the same range of activity, but is slightly less effective. Dichloropropene-dichloropropane mixture (DD) and sodium- $\mathrm{N}$-methyl-dithiocarbamate (Vapam) are considered to be mainly nematocides, but they also kill some of the other organisms, according to concentration. The effect of a heat treatment for two hours at $110^{\circ} \mathrm{C}$ is even more drastic than that of a CP treatment, killing all organisms.

Not all organisms are equally sensitive to chemicals or to heat. There are clear differences between groups of organisms and between species within the groups. This alters the population and causes certain species or groups of organisms to flare up after treatment. The flare-up may result from disappearance of antagonistic organisms and from the increase in available organic material, derived from killed organisms. In the colonization of this organic material not only the surviving organisms have to be considered, but also invaders. In general bacteria and actinomycetes resist to sterilization more than fungi and among fungi saprophytes are more tolerant than pathogens, at least in vitro (DoMsch, 1960b). Therefore, after partial soil sterilization bacteria and actinomycetes flare up and usually dominate during the first weeks or even months. Among the fungi Trichoderma viride is one of the powerful recolonizers (e.g. BRUEHL, 1952).

\subsubsection{Materials and methods}

Trial 1. Antagonistic soil of various origins was used (M 70, S 6, Valthermond). The treatments were as follows: a) 2 hours autoclaving at $110^{\circ} \mathrm{C}$; b) $\mathrm{CP}$ at $0.3 \mathrm{ml} /$ litre soil; c, d and e) DD at $0.2,0.5$ and $1.0 \mathrm{ml} /$ litre soil, respectively; f) Vapam at 0.5 $\mathrm{ml} /$ litre soil; g) control. The chemicals were applied after the soil was put into double plastic bags. Then the samples were stored for 7 days at $16-20^{\circ} \mathrm{C}$. To remove residues of the chemicals after this period, the soils were exposed to air for one day in flat layers. For each treatment 4 clay pots were filled with $2 \mathrm{~kg}$ soil each. Ophiobolus ( $1 \%$ LO; fresh weight) was added to 3 pots per treatment, and the fourth served as a control (NO). After preparing the pots 10 grains wheat were sown per pot. 
Trial 2. Antagonistic soils of various origins (M 70, U 43, Valthermond) were given the following treatments: a) $30 \mathrm{~min}$. at $\left.50^{\circ} \mathrm{C}^{4}\right)$; b) $30 \mathrm{~min}$. at $60^{\circ} \mathrm{C}^{4}$; c) 2 hours autoclaving at $110^{\circ} \mathrm{C}$; d) $\mathrm{CP}$ at $0.2 \mathrm{ml} /$ litre soil; e) $\mathrm{MB}$ at $1 \mathrm{ml} /$ litre soil; f, g and h) Pimaricin, streptomycin and Terramycin, respectively, each at 100 p.p.m., added to the soil as a solution or suspension in water; i) control. The $U 43$ soil consisted of two portions, one being very wet when treated (U $43 a$ ) (about $80 \%$ of field capacity), the other $50 \%$ of field capacity (U $43 \mathrm{~b}$ ). The treatments $\mathrm{c}, \mathrm{d}, \mathrm{e}, \mathrm{g}$ and $\mathrm{i}$ were also applied to fresh non-antagonistic $T 69$ soil. Each differently treated soil was tested in 3 clay pots, each containing $1 \mathrm{~kg}$ soil, which were treated with $L O$. A fourth pot of the treatments $\mathrm{c}, \mathrm{d}, \mathrm{g}$ and $\mathrm{i}$ was treated with DO.

Trial 3. Glass tubes $30 \mathrm{~cm}$ long and $1.7 \mathrm{~cm}$ wide were filled with antagonistic $U 43$ soil to a height of about $10 \mathrm{~cm}$. Soil moisture was adjusted to $60 \%$ of field capacity. The tubes were plugged with cotton and the lower half immersed for $30 \mathrm{~min}$. in a waterbath kept at different temperatures between $20^{\circ}$ and $100^{\circ} \mathrm{C}$. Some tubes were also autoclaved for $30 \mathrm{~min}$. at $110^{\circ} \mathrm{C}$. Each treatment was applied to five tubes. Within 5 minutes of the start of treatment, an equal temperature was reached all over the soil in the tube. Before and after the heat treatment the upper part of the tube, which had not been in contact with the water, was flamed. Surface-sterilized and pregerminated wheat seeds of checked sterility were put into the tubes, one per tube. The tubes were inoculated with 3 disks, $6 \mathrm{~mm}$ diameter, of Ophiobolus grown on PDA.

\subsubsection{Results and discussion}

Trial 1. Table 19 shows the average disease indexes per 3 pots of each treatment. Each treatment of the antagonistic soil resulted in higher disease indexes than the control, indicating that antagonism is at least partly lost. The reduction in antagonism due to $\mathrm{CP}$ was not large. The dosage effect of DD was very marked: high concentrations had a large effect; nematocidal doses $(0.2 \mathrm{ml} /$ litre soil $)$ had little effect. The effect of the heat treatment was less than expected with complete sterilization. Most likely soil is very quickly recolonized so checking Ophiobolus to some degree (LuDwiG \& HENRY, 1943). Valthermond soil reacts to the chemicals less than the clay soils. The high humus content may be responsible for adsorption of the chemicals (GoRING, 1967). Such adsorption is well known to greatly influence the effect of CP and other chemicals.

Trial 2. This experiment gives additional information on the elimination of the antagonism after treatment of the soil (table 20). First the ineffectiveness of the antibiotics is apparent. The antibiotics would be adsorbed on clay minerals and humus particles and biological degradation would take place. All other treatments were about equal in their capacity to eliminate the antagonism. The effect of the

4 Many thanks to G. J. Bollen who kindly let us use his steam/air apparatus to treat the soil below $100^{\circ} \mathrm{C}$. 
treatment at $50^{\circ} \mathrm{C}$ was rather astonishing since many micro-organisms can survive this temperature for $30 \mathrm{~min}$. After the treatments the plants growing in Valthermond soil were much less diseased than in the other soils. In this trial not only the effect of chemicals (as in trial 1), but also of the other treatments was less. This might be caused by the high humus content of the soil which protected the micro-organisms against adverse circumstances ("organic shielding"; KREUTZER, 1963; KREUTZER, 1965) and which at the same time benefited soil structure, thus stimulating the formation of new roots. The high disease index of treatment $i$ (control) of the nonantagonistic T 69 soil illustrates the high antagonism of the other soils. When a large inoculum is used the microflora of a normal soil cannot prevent the wheat plants from being completely killed by Ophiobolus.

In both the first and second experiment plants recovered little with time, so that there was clear negative correlation of the dry weight of the shoots with the disease index. This phenomenon is caused by cultivating the plants in small densely packed

Table 19. Effect of partial sterilization of antagonistic soil on the severity of disease in Ophiobolusinoculated wheat.

\begin{tabular}{|c|c|c|c|c|c|c|c|c|}
\hline \multirow[t]{3}{*}{ Soil treatment } & \multicolumn{4}{|c|}{ Valthermond soil } & \multicolumn{4}{|c|}{ M 70 soil } \\
\hline & \multicolumn{3}{|c|}{ disease index } & \multirow{2}{*}{$\begin{array}{l}\text { dry weight of } \\
\text { shoots (g) }\end{array}$} & \multicolumn{3}{|c|}{ disease index } & \multirow{2}{*}{$\begin{array}{l}\text { dry weight of } \\
\text { shoots (g) }\end{array}$} \\
\hline & $1 \mathrm{~m}^{2}$ & $2 \mathrm{~m}$ & $3 \mathrm{~m}$ & & $1 \mathrm{~m}$ & $2 \mathrm{~m}$ & $3 \mathrm{~m}$ & \\
\hline none & 0.3 & 0.5 & 0.7 & 5.9 & 0.7 & 0.5 & 0.2 & 6.7 \\
\hline $110^{\circ}, 2 \mathrm{~h}$ & 0.7 & 2.0 & 4.0 & 1.9 & 1.0 & 1.3 & 2.5 & 3.9 \\
\hline $\mathrm{CP} 0.3^{1}$ & 0.5 & 0.6 & 1.3 & 6.0 & 0.8 & 2.3 & 3.2 & 3.4 \\
\hline DD $0.2^{1}$ & 1.0 & 1.0 & 1.5 & 5.7 & 1.2 & 1.5 & 1.0 & 5.7 \\
\hline DD $0.5^{1}$ & 0.3 & 1.3 & 3.8 & 4.9 & 1.5 & 4.5 & 4.5 & 0.1 \\
\hline DD $1.0^{1}$ & 0.3 & 1.4 & 4.3 & 2.9 & 0.8 & 4.7 & 5.0 & 0.0 \\
\hline \multirow[t]{4}{*}{ Vapam $0.5^{1}$} & 0.2 & 0.8 & 1.2 & 4.5 & 1.5 & 2.9 & 3.2 & 2.5 \\
\hline & \multicolumn{4}{|c|}{ S 6 soil } & \multicolumn{3}{|c|}{ Average } & \\
\hline & \multicolumn{3}{|c|}{ disease index } & dry weight of & \multicolumn{3}{|c|}{ disease index } & \\
\hline & $1 \mathrm{~m}$ & $2 \mathrm{~m}$ & $3 \mathrm{~m}$ & & $1 \mathrm{~m}$ & $2 \mathrm{~m}$ & $3 \mathrm{~m}$ & \\
\hline none & 1.0 & 0.5 & 0.5 & 9.3 & 0.7 & 0.5 & 0.5 & \\
\hline $110^{\circ}, 2 \mathrm{~h}$ & 2.3 & 2.3 & 3.3 & 3.3 & 1.3 & 1.9 & 3.3 & \\
\hline CP $0.3^{1}$ & 1.0 & 1.5 & 2.2 & 7.1 & 0.8 & 1.5 & 2.2 & \\
\hline DD $0.2^{1}$ & 2.2 & 1.8 & 1.0 & 7.7 & 1.5 & 1.4 & 1.2 & \\
\hline DD $0.5^{1}$ & 0.7 & 2.7 & 3.7 & 2.8 & 0.8 & 2.8 & 4.0 & \\
\hline DD $1.0^{1}$ & 0.2 & 4.4 & 5.0 & 0.1 & 0.4 & 3.5 & 4.8 & \\
\hline Vapam 0.51 & 1.2 & 2.9 & 3.3 & 1.7 & 1.0 & 2.2 & 2.6 & \\
\hline
\end{tabular}


Table 20. Effect of partial sterilization of antagonistic and non-antagonistic ( $T 69$ ) soil on the severity of disease in Ophiobolus-inoculated wheat.

\begin{tabular}{|c|c|c|c|c|c|c|c|c|}
\hline \multirow[t]{3}{*}{ Soil treatment } & \multicolumn{4}{|c|}{ Valthermond soil } & \multicolumn{4}{|c|}{ M 70 soil } \\
\hline & \multicolumn{3}{|c|}{ disease index } & \multirow{2}{*}{$\begin{array}{l}\text { dry weight of } \\
\text { shoots (g) }\end{array}$} & \multicolumn{3}{|c|}{ disease index } & \multirow{2}{*}{$\begin{array}{l}\text { dry weight of } \\
\text { shoots (g) }\end{array}$} \\
\hline & $1 \mathrm{~m}^{2}$ & $2 \mathrm{~m}$ & $2 \frac{1}{2} \mathrm{~m}$ & & $1 \mathrm{~m}$ & $2 \mathrm{~m}$ & $2 \frac{1}{2} \mathrm{~m}$ & \\
\hline none & 1.5 & 0.7 & 0.7 & 2.1 & 2.3 & 1.5 & 1.3 & 1.9 \\
\hline $50^{\circ}, 30 \mathrm{~min}$ & 0.5 & 0.6 & 0.8 & 2.7 & 2.3 & 3.6 & 3.0 & 0.7 \\
\hline $60^{\circ}, 30 \mathrm{~min}$ & 0.8 & 1.0 & 1.3 & 1.7 & 3.0 & 4.0 & 3.7 & 0.8 \\
\hline $110^{\circ}, 2 \mathrm{~h}$ & 0.5 & 0.5 & 0.8 & 2.6 & 3.3 & 3.1 & 2.5 & 1.1 \\
\hline CP $0.2^{1}$ & 0.2 & 0.2 & 0.9 & 2.5 & 3.2 & 4.7 & 4.4 & 0.1 \\
\hline MB $1.0^{1}$ & 0.5 & 0.5 & 0.8 & 2.5 & 3.5 & 4.8 & 4.7 & 0.1 \\
\hline Pimaricin, 100 p.p.m. & 1.2 & 0.5 & 0.8 & 1.9 & 1.5 & 0.7 & 0.9 & 2.3 \\
\hline Streptomycin, 100 p.p.m. & 0.5 & 0.2 & 0.7 & 3.3 & 1.0 & 0.5 & 0.7 & 2.3 \\
\hline \multirow[t]{4}{*}{ Terramycin, 100 p.p.m. } & 1.5 & 0.8 & 1.0 & 1.6 & 1.5 & 0.5 & 0.5 & 2.2 \\
\hline & \multicolumn{4}{|c|}{ U 43a soil } & \multicolumn{4}{|c|}{$\mathrm{U} 43 \mathrm{~b}$ soil } \\
\hline & \multicolumn{3}{|c|}{ disease index } & dry weight of & \multicolumn{3}{|c|}{ disease index } & dry weight of \\
\hline & $1 \mathrm{~m}$ & $2 \mathrm{~m}$ & $2 \frac{1}{2} m$ & & $1 \mathrm{~m}$ & $2 \mathrm{~m}$ & $2 \frac{1}{2} \mathrm{~m}$ & \\
\hline none & 0.7 & 0.5 & 0.5 & 3.6 & 0.8 & 0.8 & 0.7 & 3.1 \\
\hline $50^{\circ}, 30 \mathrm{~min}$ & 3.0 & 4.3 & 3.6 & 0.4 & 3.5 & 4.7 & 4.1 & 0.3 \\
\hline $60^{\circ}, 30 \mathrm{~min}$. & 2.8 & 4.4 & 3.8 & 0.5 & 4.0 & 4.8 & 4.5 & 0.2 \\
\hline $110^{\circ}, 2 \mathrm{~h}$ & 3.8 & 4.4 & 3.5 & 0.6 & 3.9 & 4.0 & 3.2 & 0.6 \\
\hline CP $0.2^{1}$ & 3.7 & 4.2 & 3.2 & 0.5 & 4.0 & 4.8 & 4.5 & 0.1 \\
\hline MB $1.0^{1}$ & 4.0 & 4.7 & 4.5 & 0.1 & 4.3 & 4.9 & 4.9 & 0.0 \\
\hline Pimaricin, 100 p.p.m. & 1.5 & 0.5 & 0.0 & 3.5 & 2.3 & 1.9 & 1.4 & 2.3 \\
\hline Streptomycin, 100 p.p.m. & 1.0 & 0.2 & 0.5 & 3.4 & 0.5 & 0.3 & 0.5 & 3.7 \\
\hline \multirow[t]{4}{*}{ Terramycin, 100 p.p.m. } & 0.3 & 0.2 & 0.2 & 4.1 & 1.5 & 0.8 & 0.8 & 3.1 \\
\hline & \multicolumn{4}{|c|}{ T 69 soil } & \multicolumn{4}{|c|}{ Average (T 69 excluded) } \\
\hline & \multicolumn{3}{|c|}{ disease index } & dry weight of & \multicolumn{3}{|c|}{ disease index } & 7 \\
\hline & $1 \mathrm{~m}$ & $2 \mathrm{~m}$ & $2 \frac{1}{2} \mathrm{~m}$ & & $1 \mathrm{~m}$ & $2 \mathrm{~m}$ & $2 \frac{1}{2} \mathrm{~m}$ & \\
\hline none & 4.2 & 4.8 & 4.8 & 0.1 & 1.3 & 0.9 & 0.8 & \\
\hline $50^{\circ}, 30 \mathrm{~min}$ & & & & & 2.3 & 3.3 & 2.9 & \\
\hline $60^{\circ}, 30 \mathrm{~min}$ & & & & & 2.7 & 3.6 & 3.3 & \\
\hline $110^{\circ}, 2 \mathrm{~h}$ & 4.3 & 4.5 & 3.2 & 0.5 & 2.9 & 3.0 & 2.5 & \\
\hline $\mathrm{CP} 0.2^{2}$ & 4.5 & 4.9 & 4.8 & 0.1 & 2.8 & 3.5 & 3.3 & \\
\hline MB $1.0^{1}$ & 4.7 & 4.8 & 4.8 & 0.1 & 3.1 & 3.7 & 3.7 & \\
\hline Pimaricin, 100 p.p.m. & & & $\cdot$ & & 1.6 & 0.9 & 0.8 & \\
\hline Streptomycin, 100 p.p.m. & 3.3 & 4.8 & 4.3 & 0.3 & 0.8 & 0.3 & 0.6 & \\
\hline Terramycin, 100 p.p.m. & & & & & 1.2 & 0.6 & 0.6 & \\
\hline
\end{tabular}

$1 \mathrm{ml} /$ litre soil

$\mathbf{m}=$ month 
pots, so that lack of space, light and food prevents luxurious tillering of the remaining plants. Also the soil structure in these small pots is more easily spoiled by watering than in the larger Mitscherlich pots, thus inhibiting root development.

Trial 3. This experiment was repeated 6 times. Each tube contained one plant only. The variation between the 5 tubes of the same treatment was sometimes large. A graphical representation of the average disease indexes of the 6 consecutive trials shows the antagonism to disappear rather abruptly between $40^{\circ}$ and $60^{\circ} \mathrm{C}$ (fig. 9). The disease indexes plotted in the graphs are those assessed $21 / 2$ weeks after putting the pregerminated seeds into the tubes.

The 3 trials with partial or complete sterilization of antagonistic soil always show the elimination of antagonism. Both the general and the specific antagonism would be eliminated. The former may be rapidly restored by recolonization but no exact data about this are available. Therefore the elimination of the general antagonism will be ignored.

The elimination of antagonism by quite different treatments makes it improbable that any stable antibiotic or staling product were involved. If so, the effect of all treatments would not be expected to be the same. However, very few chemicals are stable in soil, so that the activity of microbial metabolites is based upon their continuous production. Therefore, death of the toxicant-producing organisms will result in elimination of the antagonism.

Since the amount of Ophiobolus in antagonistic soil, both in the field and in the

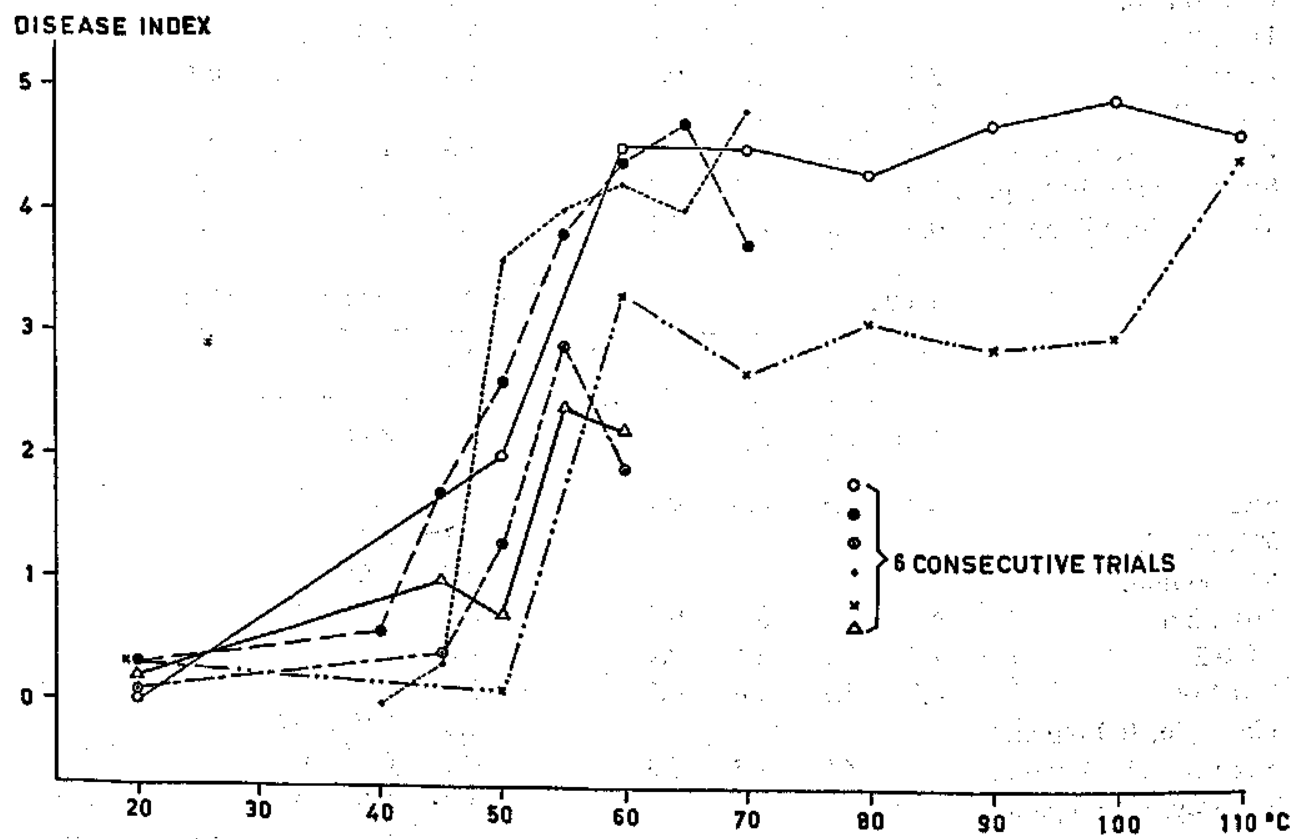

Fig. 9. Effect of heat treatment of antagonistic soll for $30 \mathrm{~min}$. at different temperatures on severity of disease in Ophiobolus-inoculated wheat. 
greenhouse, is small, it would not be very likely that killing of Ophiobolus by the treatments applied would have such a big effect if staling products of Ophiobolus were involved. But if microbial antagonists be killed, the expected effect fits the data found.

\subsection{Dilution of antagonistic soil with fresh soil}

Dilution of antagonistic soil with increasing amounts of a fresh soil will decrease the antagonism. When small amounts of antagonistic soil are diluted with large amounts of fresh soil this may be considered as inoculation of the fresh soil with antagonistic micro-organisms.

\subsubsection{Materials and methods}

In all experiments $0,1,5,10,25,50,75$ and $100 \%$ of antagonistic clay loam soils were thoroughly mixed with the complement of fresh soil. Per treatment 3 pots were filled with $3 \mathrm{~kg}$ soil each. The soil was inoculated with Ophiobolus and 10 wheat grains were sown in each pot. The various trials differed in detail.

Experiment 1. Ophiobolus inoculum was applied at a rate of $1.5 \%$ (fresh weight). As a control 3 pots with fresh soil were not inoculated (NO).

Experiment 2. Half of the samples were inoculated with $1.5 \%$ LO directly after mixing; the other half was stored at $20^{\circ} \mathrm{C}$ for three weeks before inoculation with $1.5 \%$ LO. In both cases wheat was sown directly after inoculation. As a control $1.5 \%$ DO was applied to both unmixed fresh and antagonistic soil.

Experiment 3. In this experiment an antagonistic soil (Q 107) and a fresh soil (T 69) were used. Part of them was sterilized with chloropicrin. The treated soils, indicated with $\mathrm{Q} 107 \mathrm{CP}$ and $\mathrm{T} 69 \mathrm{CP}$, respectively, and fresh $\mathrm{T} 69$ soil were mixed with antagonistic soil (Q 107 ) in different proportions, inoculated with $1 \% \mathrm{LO}$ and sown with wheat. As a control 3 pots of Q $107 \mathrm{CP}$ and $\mathrm{T} 69$ were not inoculated (NO).

\subsubsection{Results}

The disease indexes and the dry weight of the shoots at harvest of experiments 1 , 2 and 3 are given in table 21, 22 and 23, respectively. For experiment 2 the percentages killed plants are also given.

Experiment 1. (table 21). The disease indexes decreased progressively from nearly 5 to 0 with increasing proportions of antagonistic soil. The addition of only $5 \%$ antagonistic soil already reduced the disease index from 4.8 to 2.5 when assessed after 2 months. The dry weight correlated well with the disease index. The dry weight of the control was lower than expected. This must probably be attributed to a poorer soil structure since no organic material was added.

Experiment 2. (table 22). In this experiment the antagonistic soil used had an unexpectedly low antagonistic capacity, as can be seen from the rather high disease 
Table 21. Effect of dilution of antagonistic soil with fresh soil on the severity of disease in Ophiobolusinoculated wheat.

\begin{tabular}{llll}
\hline $\begin{array}{l}\text { Antagonistic soil } \\
\text { (in } \%)\end{array}$ & \multicolumn{2}{l}{ Disease index } & $\begin{array}{l}\text { Dry weight of } \\
\text { shoots }(\mathrm{g})\end{array}$ \\
\cline { 2 - 3 } & 2 months & 3 months & \\
0 & 4.8 & 4.1 & 0.5 \\
1 & 4.7 & 4.4 & 0.6 \\
5 & 2.5 & 1.0 & 4.8 \\
10 & 1.3 & 0.8 & 6.0 \\
25 & 0.6 & 0.2 & 8.9 \\
50 & 0.2 & 0 & 9.0 \\
75 & 0 & 0 & 8.6 \\
100 & 0 & 0 & 11.8 \\
& & & 4.0 \\
\hline
\end{tabular}

index with $100 \%$ antagonistic soil. Yet the same tendency as in experiment 1 could be observed: a progressive increase of the disease index and the percentage killed plants, and a decrease in dry weight with increase in percentage fresh soil. Storage of the mixed soil for 3 weeks had very little or no effect on the disease index, but the percentage killed plants after two months was appreciable higher in the stored soil. After

Table 22. Effect of dilution of antagonistic soll with fresh soll on the severity of disease in Ophiobolusinoculated wheat. Antagonistic soil of a low antagonistic capacity.

\begin{tabular}{|c|c|c|c|c|c|c|c|c|c|c|}
\hline \multirow{4}{*}{$\begin{array}{l}\text { Antago- } \\
\text { nistic } \\
\text { soil } \\
\text { (in } \% \text { ) }\end{array}$} & \multicolumn{5}{|c|}{ Inoculation and sowing immediately } & \multicolumn{5}{|c|}{$\begin{array}{l}\text { Inoculation and sowing } 3 \text { weeks after } \\
\text { mixing soil }\end{array}$} \\
\hline & \multicolumn{5}{|c|}{ date of assessment (months) } & \multicolumn{5}{|c|}{ date of assessment (months) } \\
\hline & & 2 & & 4 & & & 2 & & 4 & \\
\hline & $\begin{array}{l}\text { disease } \\
\text { index }\end{array}$ & $\begin{array}{l}\% \text { killed } \\
\text { plants }\end{array}$ & $\begin{array}{l}\text { disease } \\
\text { index }\end{array}$ & $\begin{array}{l}\% \text { killed } \\
\text { plants }\end{array}$ & $\begin{array}{l}\text { dry wt } \\
\text { (g) }\end{array}$ & $\begin{array}{l}\text { disease } \\
\text { index }\end{array}$ & $\begin{array}{l}\% \text { killed } \\
\text { plants }\end{array}$ & $\begin{array}{l}\text { disease } \\
\text { index }\end{array}$ & $\begin{array}{l}\% \text { killed } \\
\text { plants }\end{array}$ & $\begin{array}{l}\text { dry wt } \\
\text { (g) }\end{array}$ \\
\hline $\mathbf{0}$ & 4.5 & 42 & 4.8 & 96 & 0.0 & 4.9 & 88 & 4.7 & 96 & 0.0 \\
\hline 1 & 4.5 & 41 & 4.5 & 86 & 0.2 & 4.9 & 88 & 4.7 & 94 & 0.0 \\
\hline 5 & 4.5 & 50 & 4.9 & 96 & 0.0 & 4.6 & 68 & 4.0 & 74 & 0.3 \\
\hline 10 & 4.2 & 26 & 4.2 & 78 & 0.3 & 4.7 & 56 & 3.9 & 64 & 0.3 \\
\hline 25 & 4.0 & 19 & 3.3 & 63 & 1.5 & 4.1 & 58 & 3.5 & 67 & 0.7 \\
\hline 50 & 3.8 & 22 & 3.6 & 59 & 1.3 & 4.3 & 52 & 3.3 & 56 & 0.7 \\
\hline 75 & 3.8 & 9 & 3.0 & 55 & 1.3 & 4.1 & 41 & 2.8 & 45 & 1.1 \\
\hline 100 & 3.7 & 12 & 1.9 & 36 & 2.7 & 3.9 & 35 & 2.9 & 48 & 0.9 \\
\hline $100, \mathrm{DO}$ & 0 & 0 & 0 & 0 & 3.4 & 0 & 0 & 0 & 0 & 1.7 \\
\hline $0, \mathrm{DO}$ & 0 & 0 & 0 & 0 & 4.9 & 0 & 0 & 0 & 0 & 2.7 \\
\hline
\end{tabular}


Table 23. Effect of dilution of antagonistic soil with differently treated soils. $Q 107$ is antagonistic soil; $T 69$ is fresh soil.

\begin{tabular}{|c|c|c|c|c|c|c|}
\hline \multirow{2}{*}{$\begin{array}{l}\text { Antagonistic soil } \\
(\text { in } \%)\end{array}$} & \multicolumn{2}{|c|}{ Q 107 CP soil } & \multicolumn{2}{|c|}{ T 69 CP soil } & \multicolumn{2}{|c|}{ T 69 soil } \\
\hline & $\begin{array}{l}\text { disease } \\
\text { index }\end{array}$ & $\begin{array}{l}\text { dry weight } \\
(\mathrm{g})^{2}\end{array}$ & $\begin{array}{l}\text { disease } \\
\text { index }{ }^{1}\end{array}$ & $\begin{array}{l}\text { dry weight } \\
(\mathrm{g})^{2}\end{array}$ & $\begin{array}{l}\text { disease } \\
\text { index }^{1}\end{array}$ & $\begin{array}{l}\text { dry weight } \\
(\mathrm{g})^{2}\end{array}$ \\
\hline 0 & 0.5 & 7.7 & 4.8 & 0.7 & 3.2 & 1.9 \\
\hline 1 & 0.5 & 10.1 & 3.3 & 2.8 & 2.2 & 3.2 \\
\hline 5 & 0.5 & 9.9 & 2.3 & 5.4 & 2.2 & 3.4 \\
\hline 10 & 0.5 & 10.6 & 1.0 & 5.6 & 1.8 & 4.5 \\
\hline 25 & 0.3 & 10.8 & 1.3 & 5.8 & 0.7 & 6.6 \\
\hline 50 & 0 & 11.2 & 0.5 & 7.1 & 1.0 & 7.3 \\
\hline 75 & 0 & 10.0 & 1.0 & 8.0 & 0.8 & 9.3 \\
\hline 100 & 0.4 & 8.2 & 0.4 & 8.2 & 0.4 & 8.2 \\
\hline $0, \mathrm{NO}$ & 0 & 7.9 & & & 0 & 6.0 \\
\hline
\end{tabular}

12 months after sowing.

23 months after sowing.

four months the difference had disappeared. As can be seen from both controls (DO), growth of the plants after storage was less, which might explain the earlier killing of the plants.

Experiment 3. (table 23). Unexpectedly the CP treatment had little effect on the antagonism in the $Q 107$ soil, so that most of the antagonistic activity was still present. Therefore, after mixing with untreated $Q 107$, only a small decrease in disease index and a small increase in dry weight was found. Addition of antagonistic Q 107 soil to $\mathrm{T} 69$ and $\mathrm{T} 69 \mathrm{CP}$ markedly reduced the disease indexes. This agrees with experiments 1 and 2 . The difference between $T 69$ and $T 69 \mathrm{CP}$ was only apparent with 0 and $1 \%$ antagonistic soil; there the disease index of $\mathrm{T} 69 \mathrm{CP}$ was higher.

\subsubsection{Discussion}

The overall agreement of the 3 experiments can also be expressed in a graph (fig. 10), in which the disease indexes of experiments 1 and 3 and the percentage killed plants of experiment 2 (always according to the situation 2 months after sowing) are plotted against logarithm percentage antagonistic soil. The data of experiment 3, Q $107 \mathrm{CP}$ are not plotted. The points of each experiment form roughly a straight line. The same holds when the results are plotted on logarithmic probability paper. This picture is reminiscent of the action of toxicants in vitro. However, this similarity would not be expected at first sight, since soil strongly adsorbs many materials, as also hinted for the antibiotics used in experiment 2 of 6.1. Also, the lower the concentration of a chemical compound, the higher the proportion adsorbed. 
Therefore, if the antagonistic soil is effective owing to a chemical compound present in it, the effect will tend to be proportionally smaller or zero at low percentages antagonistic soil. No effect will be expected when the soil mixture contains for instance less than $10 \%$ antagonistic soil. But the picture can be explained by allowing that antibiotics in soil may be continuously produced by micro-organisms, so that the effect of adsorption will be overcome, even with as little as $1 \%$ antagonistic soil.

The possibility that staling causes the antagonism is excluded by the results of these experiments. Dilution with large amounts of fresh soil would certainly have eliminated staling factors.

The 'straight lines' of figure 10 also show that mixing antagonistic soil with nonantagonistic soil does not produce an effect bigger than could be ascribed to the amount of antagonistic soil present in the mixture. Thus, the antagonistic micro-organisms have not multiplied and become active in the fresh soil. This agrees well with practical experience of inoculation of micro-organisms into soil. Since in principle every

DISEASE INDEX

$\%$ KILLED PLANTS

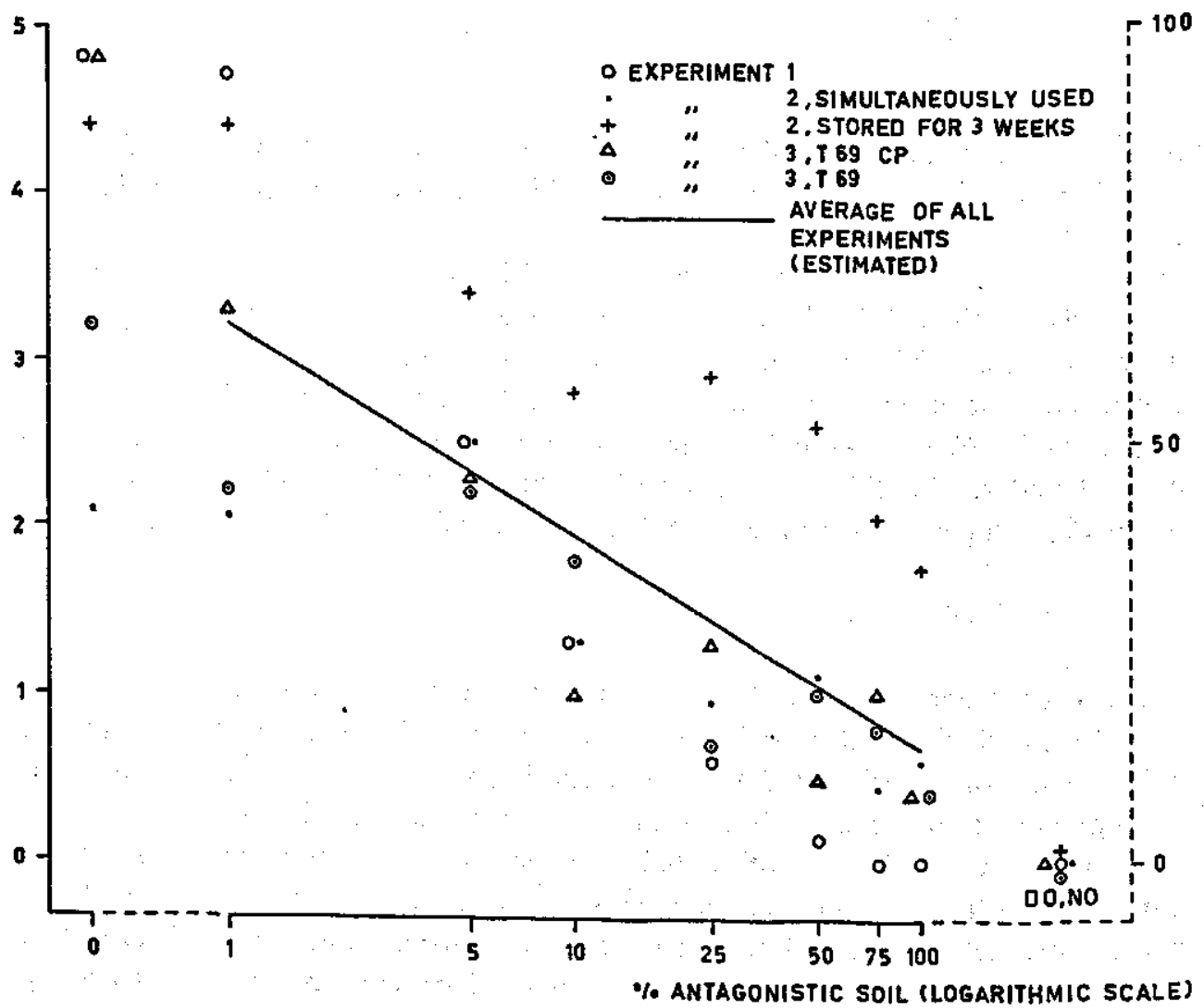

Fig. 10. Effect of dilution of antagonistic soil with fresh soil on severity of disease in Ophiobolusinoculated wheat. DO, NO = non-inoculated controls (see text). 
micro-organism is everywhere, lack of particular organisms at a given site indicates the unsuitability of this site for these micro-organisms. Inoculation with microorganisms will not lead to their multiplication. This also follows from the experiment with partially sterilized soil (experiment $3: \mathrm{T} 69 \mathrm{CP}$ ). At the rate of 0 and $1 \%$ antagonistic soil the disease index of T $69 \mathrm{CP}$ is higher than of $\mathrm{T} 69$. This can only be explained by the greater activity of the microflora of T 69 than of $\mathrm{T} 69 \mathrm{CP}$; thus the antagonistic microflora has not even filled the vacuum of $\mathrm{T} 69 \mathrm{CP}$. In the mixture with $5 \%$ antagonistic soil the difference has disappeared already, which indicates that at this small percentage the specific antagonism (decline) of the small amount of antagonistic soil already overshadows the difference in general antagonism (reduction) of $\mathrm{T} 69 \mathrm{CP}$ and $\mathrm{T}$ 69. The lack of progress of the antagonistic soil microflora at the expense of the microflora of a fresh soil is also demonstrated in experiment 2: storage of the mixtures for 3 weeks does not increase the antagonistic effect.

\subsection{The antagonistic activity of soil extracts}

It is disputed whether any antibiotic activity of a sterilized soil extract may be expected. Most authors admit the presence of antibiotics in the soil but it is generally agreed that extraction of antibiotics is difficult if not impossible. BRIAN (1957) and PARK (1967) survey literature on this subject; it will not be repeated here but some general points should be stressed:

1. In the soil adsorption and biological degradation of antibiotics occur.

2. If sterile soils amended with organic material are inoculated with special organisms antibiotics can be demonstrated (e.g. GotTLIEB, SimINOFF \& MARTIN, 1952; GREGORY et al., 1952; GrossBaRD, 1951). In sterile, unamended or non-sterile amended soils this is much more difficult, though sometimes possible (e.g. GoTTLIEB \& Siminofr, 1952; Hessayon, 1951; SMITH \& AshWORTH, 1965; WRIGHT, 1954). In unsterile unamended soil the presence of antibiotics has seldom been fully proved. The most convincing examples of antibiotic activity of extracts of such soils which had passed through bacterial filters are given by VAARTAJA \& AGNIHOTRI (1967) and WINTER $(1940,1944)$.

3. Antibiotics can readily be demonstrated in pieces of organic material in unsterile soil. But in the total soil mass antibiotics are too diluted (WrIGHT, 1956).

The positive results of WINTER $(1940,1944)$, who demonstrated an adverse effect of soil extracts upon the growth of Ophiobolus, were the incentive for experiments with extracts of antagonistic and non-antagonistic soil.

\subsubsection{Materials and methods}

Equal amounts (w/w; fresh weight) of antagonistic (LO) or non-antagonistic (DO or NO) soil (soil at about $50 \%$ of field capacity) and tap water were shaken on a moving table for 2 hours. Before and during shaking the soil suspension was thoroughly stirred for a while. After shaking the suspension was centrifuged (15 min. 
at 3000 r.p.m.) and a clear extract was obtained which was filtered to remove floating pieces of organic material and was subsequently concentrated 10 times in a vacuum evaporator at $35^{\circ}$ to $40^{\circ} \mathrm{C}$. Then the extract was again centrifuged at 3000 r.p.m. for $15 \mathrm{~min}$. and sterilized through a glass filter (P5). The extracts thus obtained were used for experiments of the following types:

a. Equal amounts of double strength PDA or WA (water agar) and soil extract were poured into Petri dishes. The radial growth of colonies of Ophiobolus inoculated upon this medium was measured.

b. Equal amounts of potato dextrose broth and soil extract $(10 \mathrm{ml}$ of each) in $100 \mathrm{ml}$ Erlenmeyer flasks inoculated with Ophiobolus, were shaken on a moving table for 7-10 days at room temperature. Then the dry weight of Ophiobolus was measured. c. In some cases antagonistic (LO) and non-antagonistic (DO) soils were directly used. In Petri dishes $30 \mathrm{~g}$ soil (fresh weight) was sterilized with ethyleneoxide or by autoclaving $30 \mathrm{~min}$. at $110^{\circ} \mathrm{C}$. The soil was covered with PDA or WA. The radial growth of Ophiobolus inoculated upon it was measured.

d. Wheat was grown in glass tubes (for instance culture tubes) with river sand under non-sterile conditions. Per tube three wheat grains (five in some experiments with bigger tubes) were sown and each inoculated with a disk, $6 \mathrm{~mm}$ diameter, of Ophiobolus grown on PDA placed under the seed. The plants were watered regularly with soil extracts or with tap water, the latter as a control. Each treatment was applied to at least 5 tubes. After $21 / 2-3$ weeks the plants were taken out and the length of runner hyphae growing along the roots was measured under dissecting microscope. The disease index of the plants was also assessed; since the two characteristics correlated well, only the length of the runner hyphae was used for calculations.

\subsubsection{Results and discussion}

The techniques $a, b$ and $c$ to assess the activity of antibiotics in soil extracts or directly in the soil did not yield any valuable information. The results were very inconsistent and the differences in effect between $L O$ and DO soil extracts were always small in relation to variation within treatment.

Several repetitions of the type of experiment described under $d$, showed that the extract of LO soil caused markedly less growth of runner hyphae of Ophiobolus than extracts of DO and NO soil or tap water. Table 24 gives the figures of a representative experiment. This experiment clearly demonstrates the presence of an antibiotic in the soil extract. The antibiotic is partially fungistatic at the concentration used. Sometimes differences between $\mathrm{LO}$ and the control extracts (including water) were less clear
or even absent.

The demonstration of an antibiotic disproves hyperparasitism as the cause (or at least as the major cause) of the antagonism. According to Boosalus (1964) the effect of hyperparasitism is normally too small to be effective. The very strong antagonism to Ophiobolus therefore had already been assumed not to be due to hyperparasitism. In another experiment of type $d$ the effect of treating the soil for $30 \mathrm{~min}$. at $60^{\circ} \mathrm{C}$ 
Table 24. Effect of extract of antagonistic soil on growth of runner hyphae of Ophiobolus.

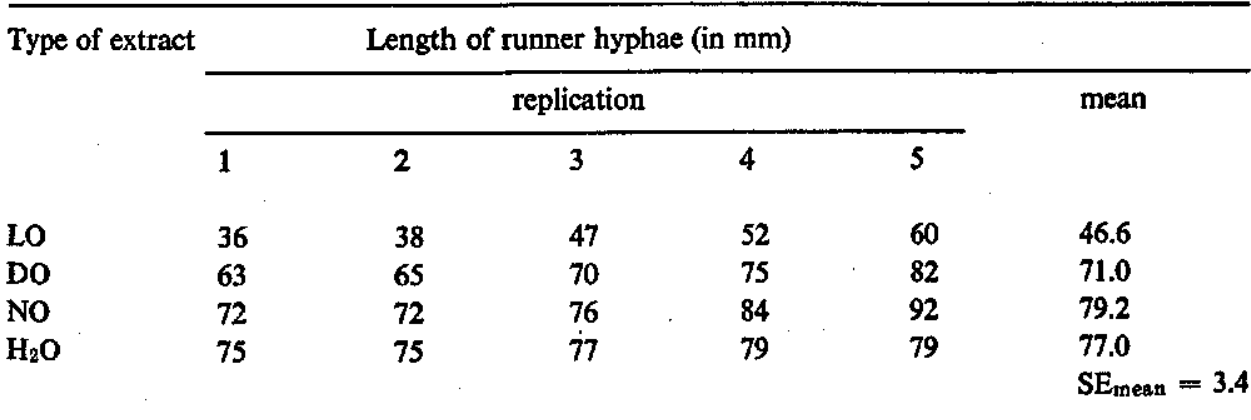

was examined by preparing a soil extract directly after the treatment of the soil. Also the influence of autoclaving a normal soil extract for $30 \mathrm{~min}$. at $110^{\circ} \mathrm{C}$, instead of sterilizing it through a glass filter, was determined (table 25). It can be seen that the normal extract of $\mathrm{LO}$ soil, the extract of $60^{\circ} \mathrm{C}$-treated $\mathrm{LO}$ soil and the autoclaved extract of LO soil cause significantly less growth of runner hyphae of Ophiobolus than water or the same types of extracts of DO soil. From 6.1 it is known that treatment of $\mathrm{LO}$ soil at $60^{\circ} \mathrm{C}$ for $30 \mathrm{~min}$. completely eliminates the antagonism. Yet the extract prepared directly after the treatment is active. This supports the view that heat treatment does not destroy the antibiotic(s) but kills the antibiotic-producing micro-organism(s), so that production of new antibiotic is halted, whereas the antibiotic present in the soil is gradually adsorbed or degraded biologically. The figures of table 25 show that the antibiotic(s) can even resist $110^{\circ} \mathrm{C}$ for $30 \mathrm{~min}$.

Table 25. Effect of extract of antagonistic soil on growth of runner hyphae of Ophiobolus.

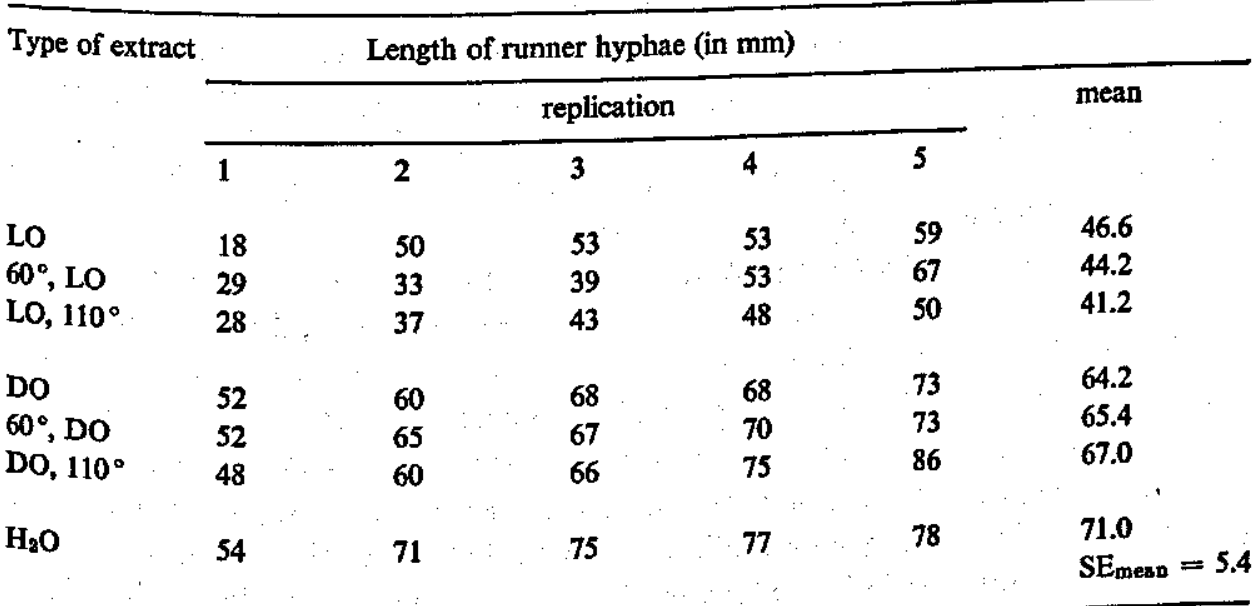

$60^{\circ}, \mathrm{LO}=$ extract of $60^{\circ} \mathrm{C}$-treated antagonistic soil.

LO, $110^{\circ}=$ extract of antagonistic soil; extract autoclaved.

$60^{\circ}, \mathrm{DO}$ and DO, $110^{\circ}$ : see LO. 
Isolation and identification of the antibiotic(s) was not possible, because the technique used to demonstrate activity is very laborious. Better techniques, yielding information about the activity of an extract more quickly and with less material, need first to be evolved.

The trials of type $\mathrm{d}$ have shown the antibiotic activity of a sterile extract of a non-sterile soil which is slightly supplemented with organic material four times a year. The organic material itself is not essential, since LO soil is active and DO soil is not. Yet in most experiments growth of runner hyphae was slightly less with extract of DO soil than with tap water. But this reduction of growth was never significant and was much smaller than reported by WINTER $(1940,1944)$.

\subsection{Discussion}

The experiments described in this chapter clearly illustrate that the antagonism to Ophiobolus is microbial and that the antagonistic micro-organisms work by producing antibiotics. Whether there are also other mechanisms of antagonism has not been investigated. The possible role of competition for food and hyperparasitism as additional mechanisms should not be excluded.

The antagonists still have to be specified. The experiment of $6.1 \mathrm{might}$ give some information on this. It is remarkable that a temperature as low as $50^{\circ} \mathrm{C}$ for $30 \mathrm{~min}$. in experiment 2, or even $45^{\circ} \mathrm{C}$ in experiment 3 reduces antagonism.

Thus the organisms are very sensitive to temperature. Most bacteria and actinomycetes can very well stand such low temperatures for $30 \mathrm{~min}$.; the same holds for many fungi. However, there are fungi which are clearly more sensitive. But it would be premature to conclude from this that a micro-organism, not capable of withstanding $50^{\circ} \mathrm{C}$ or even $45^{\circ} \mathrm{C}$ for $30 \mathrm{~min}$. and thus most likely a fungus, is responsible for the antagonism. Another possibility would be to postulate a balanced association of micro-organisms, which, as such, antagonizes Ophiobolus. Killing some members of this association would disturb the equilibrium and so change the circumstances for all organisms left, and this might prevent their antagonistic activity. Some points will be discussed to see whether they are in favour of one organism or of a balanced association with few to many micro-organisms.

1. In the experiment of 5.2.3 it took some months to induce decline. When circumstances are favourable, one organism might increase much faster, thus rapidly initiating decline. It might take longer to establish a balanced association. However, the normal time for a parasite of a crop grown in monoculture to establish itself could be taken as evidence that build-up of one organism usually takes some months.

2. In the experiment of 5.2.3 antagonism is established earlier in well equilibrated ('old') soil than in virgin ('young') soil. It is evident that in the 'old' soil the microflora will be more complex than in the 'young'. From this it may be concluded that if one organism causes decline this organism will establish itself easier in the 'young' soil. But, as stated already, antagonism was established easier in the 'old' soil.

3. The results of treatment at $50^{\circ} \mathrm{C}$ of the experiments 2 and 3 described in 6.1 do 
not completely correspond. In experiment 2 antagonism strongly decreased at $50^{\circ} \mathrm{C}$, though always a bit less than at $60^{\circ} \mathrm{C}$, whereas in experiment 3 treatment at $50^{\circ} \mathrm{C}$ strongly decreased antagonism sometimes and only slightly or not at all otherwise. Fig. 9 gives the impression of a decrease in antagonism over a range of about $20^{\circ} \mathrm{C}$. Since the thermal death-point of a given structure of one organism is constricted to a range of only a few degrees (BoLLEN, personal communication) ${ }^{5}$, this phenomenon might not be expected if one organism was involved. A balanced association, however, would be disturbed progressively as more of the micro-organisms are killed. This would explain the progressive decrease in antagonism with increasing temperature. 4. Decline occurs with many different diseases (5.1). It cannot be expected that the pathogens involved all have just one or a very few specific antagonists. It is more likely that dominance of a pathogen is corrected by a reaction of a significant part of the soil microflora.

5. Decline occurs in soils with largely different texture, mineral composition, humus content and $\mathrm{pH}$ (cf. 5.2.3). It can hardly be assumed that one or a few special organisms can effectively antagonize Ophiobolus under such widely different conditions. A balanced association of micro-organisms is more flexible.

6. Decline is so specifically induced by only virulent Ophiobolus, that it might be assumed that one organism is effective. On the other hand it is not known whether decline depends on one or more antibiotics (cf. 6.3). Moreover, even if one antibiotic comes into play, it might be produced by several organisms.

The above points tend to favour the hypothesis of a balanced association of micro-organisms as the background of the antagonism. It should be stressed, however, that the number of participating antagonists is not essential in the picture of the decline mechanism described in this paper.

${ }^{5}$ Most literature about the effect of temperature on killing the micro-organisms concerns variable periods at a fixed temperature; Bollen has tested the effect of various temperatures with a fixed period. 


\section{Search for the organism(s) antagonizing Ophiobolus}

Now that the microbial origin of decline is established, it is worthwhile tracing the organism(s).

As discussed already (5.2.4) both antagonistic and non-antagonistic soils contain antagonists, responsible for decline and reduction, respectively. In the literature quite a number of antagonists are reported to occur in normal soil. Trichoderma viride, mentioned by many authors in relation to several diseases, is also considered an antagonist of Ophiobolus (e.g. LaL, 1939; PonomareVA, 1965; SKIPSNA, 1963); it might even be a hyperparasite (Ponchet \& Coppenet, 1962; SLAGG \& Fellows, 1947). Numerous fungi found to be antagonistic to Ophiobolus in vitro were listed by MANGAN (1966, 1967). Numerous fungi and bacteria are reported to be antagonistic in vitro as well as in vivo (BroAdFoot, 1933a; BRÖMMELHUES, 1935; FLÜCK, 1955; LAL, 1939; SANFORD \& BROAdFoOt, 1931; SIEGLE, 1961; SLAGG \& Fellows, 1947; ZoGG, 1950; ZOGG, 1951). Other workers considered actinomycetes (EHLE, 1965; EHLE, 1966a; EHLE, 1966b; SCHMIDT, 1962). In contrast to that research my search for antagonists contrasted antagonistic soil and normal soil.

Only fungi were considered in any detail when looking for antagonists. The difficulties in identification of bacteria and actinomycetes were largely responsible for this restriction.

\subsection{Number and antagonistic activity of micro-organisms isolated from soil}

Since in the experiment described in $5.2 .3 \mathrm{a}$ big difference in antagonistic activity was found between LO and DO-treated soil, whereas both soils received about the same amount of organic matter, it could be expected that the total number of microorganisms, irrespective of species, has no influence upon the specific antagonism. This has also been expressed in figure 8. Indeed, when counting the numbers of fungi, bacteria and actinomycetes in LO, DO and NO soils with dilution plates and using different agar media, no differences could be detected. Neither was the humus content differently influenced by the amendments. Therefore the antagonism should be based upon one or another qualitative character. This contrasts with most cases of increased general antagonism after treatment of a soil reported in the literature, in which the number of micro-organisms is important (compare 8.1). Thus GrossmanN (1954) and EHLE $(1965,1966 \mathrm{~b})$ found a higher degree of apparently general antagonism after green manuring through a rise in number of micro-organisms as a whole. 
LOCHHEAD \& LANDERKIN (1949), moreover, found higher percentages antagonistic actinomycetes, though to other pathogens than Ophiobolus, after green manuring with soya bean.

With soil-dilution plates, Warcup's soil plates (JoHnson et al., 1959) and HARLEY \& WAID's (1955) root-washing technique, an effort was made to establish quantitative differences in the fungal flora of LO, DO and NO soils or in the rhizospheres of plants growing in these soils. With identification up to genera only, except for a few important organisms, virtually no differences between the various soils were found. Only Gliocladium roseum tended to occur slightly more in antagonistic soil. In a small experiment the addition of spores of Gliocladium roseum both to natural and sterilized soils did not depress the disease index of Ophiobolus-inoculated wheat sown in these soils. This agreed with the results of the experiment of 5.3.2.

When random isolates (fungi, bacteria and actinomycetes) from fresh and antagonistic soils were inoculated onto agar opposite Ophiobolus, no difference could be found in the percentage isolates antagonistic to Ophiobolus. (234 isolates were tested.)

\subsection{Fungi emerging from straws buried in soil}

Since the rather trivial approach of 7.1 completely failed, another approach has been tried. One could imagine for instance that different soil organisms differ characteristically in their affinity to pieces of organic material colonized by Ophiobolus or not.

\subsubsection{Materials and methods}

Wheat straws were split longitudinally and subsequently cut into $1 \mathrm{~cm}$ pieces. Portions consisting of 275 pieces in a $100 \mathrm{ml}$ Erlenmeyer flask were moistened with $7 \mathrm{ml}$ potato dextrose broth, autoclaved at $120^{\circ} \mathrm{C}$ for $30 \mathrm{~min}$. and inoculated with Ophiobolus. After $2 \frac{1}{2}$ weeks Ophiobolus had sufficiently colonized the straws. Then half of the flasks was sterilized with chloropicrin; the other half was not treated. These straws are indicated as DO straw and LO straw, respectively. A control portion of straws was not inoculated with Ophiobolus at all (NO straw). Of differently treated clay loam soils, LO, DO and NO, of which only LO soil was antagonistic to Ophiobolus, portions of $100 \mathrm{~g}$ (dry weight) were adjusted to a moisture content of $35 \%$ of the field capacity and put into $370 \mathrm{ml}$ glass tumblers ( 12 tumblers per soil type). Per tumbler 45 pieces of straw of one of the 3 treatments at a time were thoroughly mixed through the soil. The tumblers were covered with a thin sheet of polythene to prevent evaporation while enabling $\mathrm{CO}_{2}$ exchange and incubated at $23^{\circ} \mathrm{C}$ for 3 and 6 weeks, respectively. The straws were then recovered from the soil and washed with tap water. Subsequently they were surface-sterilized for $1^{1 / 2}$ and 2 hours, respectively, with sodium hypochlorite solution (eau de Labarraque), which is not selective as a disinfectant (WALKER, 1941). Then they were rinsed in sterile water for two subsequent periods of $30 \mathrm{~min}$. Half the straws were plated out on PDA with 50 p.p.m. Terramycin and half on cellulose agar with 50 p.p.m. Terramycin. The cellulose agar contained 
Table 26. Counts of fungi of different genera on 20 pieces of straw after 3 or 6 weeks incubation in different soils. Treatment of straw Fusarium Pythium

Mucoraceae

Trichoderma

$\begin{array}{lll}\text { soil straw agar } & \begin{array}{l}\text { disinfection } \\ \text { time (h) }\end{array}\end{array}$

LO LO PDA $1 \frac{1}{2}$

$\begin{array}{lll}\text { LO LO } & \text { PDA } & 1 \frac{1}{2} \\ & \text { CA } & 2 \\ & & 1 \frac{1}{2} \\ & & 2\end{array}$
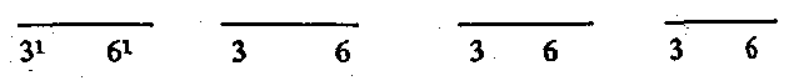

$\begin{array}{llll}1 & 2 & & 1 \\ 6 & & 4 & \\ 3 & & 1 & 1 \\ 2 & & & \end{array}$

DO PDA $1 \frac{1}{2}$

$\begin{array}{rr}7 & 1 \\ 14 & 5 \\ 9 & 4 \\ 16 & 12\end{array}$

216

$\begin{array}{rr}2 & 1 \\ 11 & 3\end{array}$

CA $\quad 1 \frac{1}{2}$

$2 \frac{1}{2}$

NO PDA $1 \frac{1}{2}$

83

1210

216

88

CA $1 \frac{1}{2}$

165

DO LO

PDA $1 \frac{1}{2}$

CA : $\quad 2$

3 :

18

5.2

$\begin{array}{rrrr}13 & 2 \\ 2 & 13 & 5\end{array}$

DO PDA $1 \frac{1}{2}$

CA $\quad \begin{aligned} & 2 \\ & 1 \frac{1}{2}\end{aligned}$

$18 \quad 11$

$11 \quad 10$

$13 \quad 16$

$19 \quad 11$

NO PDA $1 \frac{1}{2}$

$\begin{array}{ll}\text { PA } & { }^{1 \frac{1}{2}} \\ & \mathbf{1 1} \\ 2 & 2\end{array}$

17 5

203

$15 \quad 10$

$19 \quad 13$

(1)
. 10
13
2

16

$1 \cdots 4$

NO LO PDA $1 \frac{1}{2}$

CA $\quad 2^{2}$

$\begin{array}{rrrrr}1 & 1 & 6 \\ 2 & 4 & 9\end{array}$

DO PDA 1

$\begin{array}{ll}\text { PDA } & 2 \\ \text { CA } & 1 \frac{1}{2} \\ 2 & 2\end{array}$

NO PDA $1 \frac{1}{2}$

$\mathrm{CA}^{2}{ }_{2}^{2}$

25

$\begin{array}{lll} & \text { CA } & 2 \\ \text { NO } & \text { PDA } & 1 \frac{1}{2} \\ & \text { CA } & 1 \\ & & 2\end{array}$

Sum

$22 \quad 10$

2016

$16 \quad 15$

$21 \quad 12$

$22 \quad 12$

$17 \quad 13$

$12 \cdot 12$

$19 \quad 7$

$\begin{array}{rr}2 & 10 \\ 1 & 13 \\ 8 & 8 \\ 8 & 7 \\ & 11 \\ 2 & 11 \\ 7 & 4 \\ 12 & \end{array}$

$429 \quad 238$

$66 \quad 175$

9
12

2

2

(1)

$9 \quad 11 \quad 3$

$$
1
$$

$7 \quad 1$

$\begin{array}{rr}13 & 1\end{array}$

1

1 time of incubation of straws in soil (in weeks). 


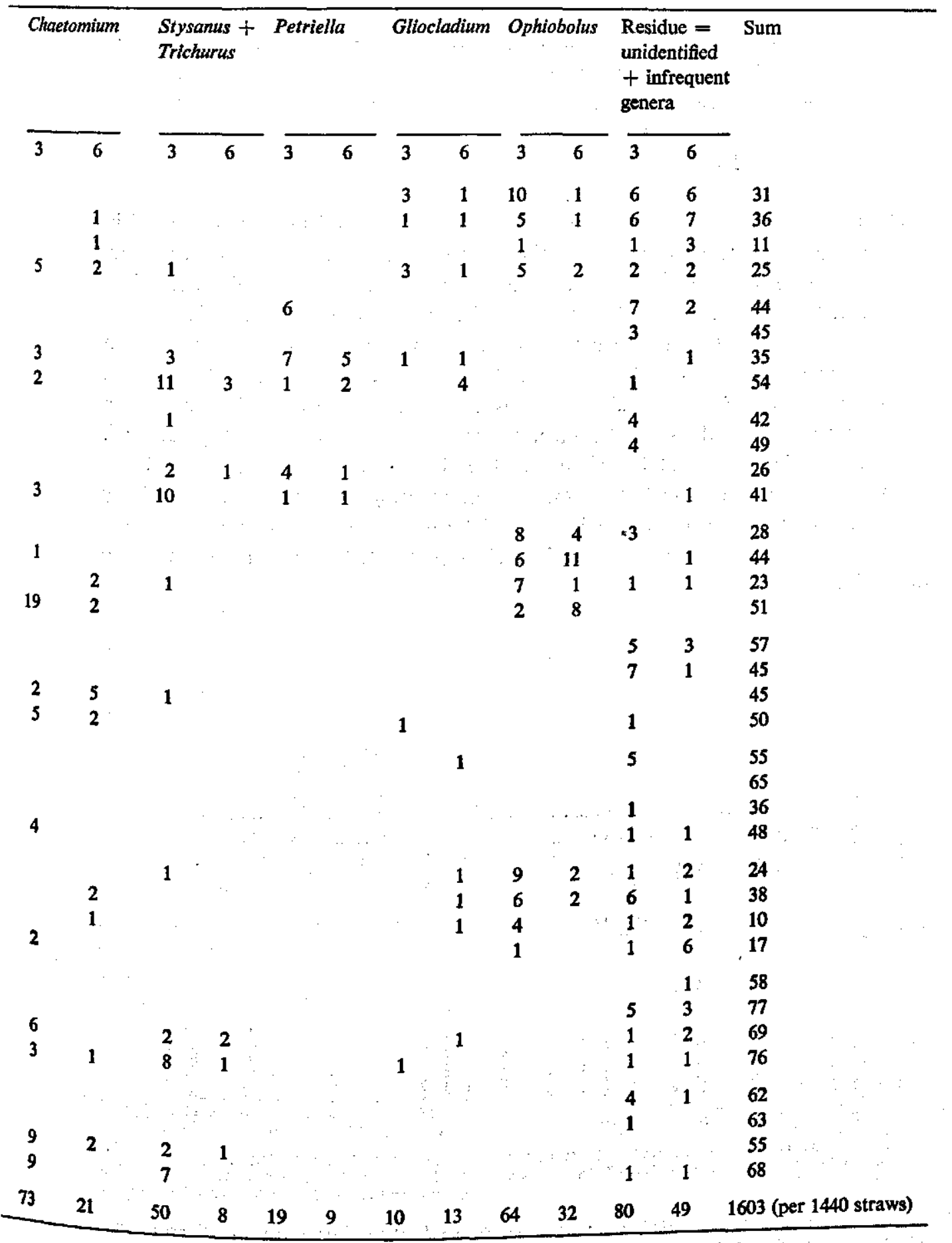




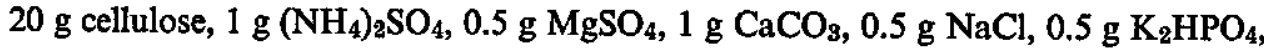
and $15 \mathrm{~g}$ agar in 1 litre distilled water (WITKAMP, 1960). After 3 days, and 1 and 2 weeks at $23^{\circ} \mathrm{C}$ the fungi growing out of the straws were examined. Genera were identified. A residue consisted of fungi of rare occurrence or difficult to identify. Per treatment 5 Petri dishes with 4 straws each were examined.

\subsubsection{Results}

The fungal genera and the numbers of colonies per genus found are presented in table 26 and figure 11. In the figure only the most interesting treatments are separated. The significance of the effects of differences in straw and soil and their interaction, as indicated in figure 11, was calculated by variance analysis (factorial design). Most effects were significant. Often the number of fungi on NO and DO straws was much higher than on LO straws. There was no difference between NO and DO straws. Most effects found to be significant in this experiment were also significant in a second experiment of the same design. But some of them were completely reversed. For example, in experiment I Pythium was found most frequently on DO and NO straws, in experiment II on LO straws. In both experiments the effects were highly significant. For comparison the significance of effects of both experiments is indicated in table 27, and the concordance of their tendencies is noted. Details are given in the discussion.

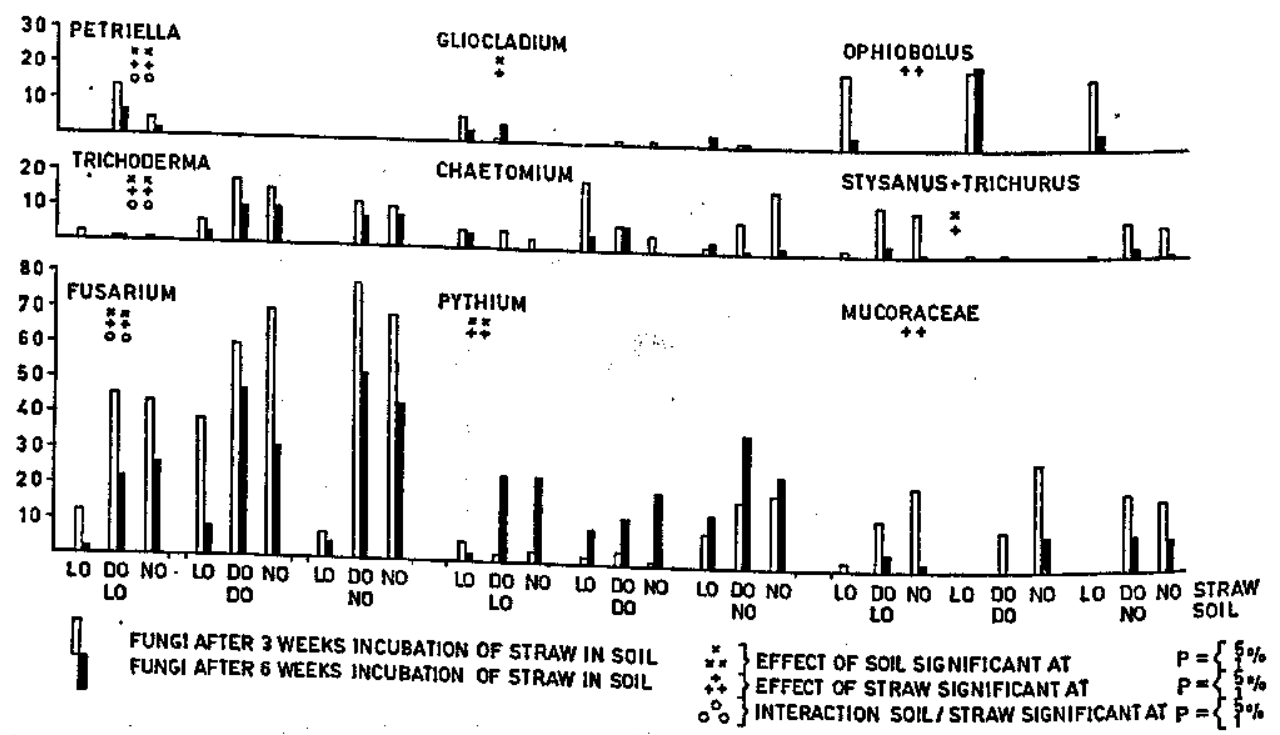

Fig. 11. Counts of fungi of different genera on 80 straws kept for 3 or 6 weeks in different soils. Significance of effects indicated for the sum of the counts at 3 and 6 weeks. 


\subsubsection{Discussion}

If a particular fungus is involved in the antagonism, this fungus might be expected: 1. to occur in antagonistic soil more frequently than in other soil (prerequisite); 2. to colonize straws precolonized by Ophiobolus (LO straw) relatively more easily than other fungi (possibility).

The first property is shown only by Gliocladium, Petriella and Stysanus + Trichurus in the first experiment. This is affirmed in the second experiment, whose figures are not represented, though Gliocladium also occurred very often in NO soil. The second property is shown by Chaetomium and Gliocladium in the first experiment. Though only Gliocladium occurs significantly more frequently on LO straws, both are at least much better colonizers of precolonized straws than the other fungi, which all colonize DO and NO straws significantly better than LO straws. In the second experiment this effect was not confirmed for Chaetomium, but Gliocladium, Petriella and Stysanus + Trichurus did occur more frequently on precolonized straws. Thus agreement only exists for Gliocladium.

A positive reaction for the first property seems a prerequisite for a potential antagonist. Though it cannot be stated with certainty, it seems rather improbable that an antagonist would have as much difficulty in colonizing straw precolonized by Ophiobolus as a non-antagonistic fungus. Therefore Gliocladium, which shows both

Table 27. Significance of the effects of soil type, treatment of straw, and their interaction on the number of fungi of different genera found on the straws after incubation in the soil for 3 or 6 weeks. Concordance of 2 experiments.

\begin{tabular}{|c|c|c|c|c|c|c|c|c|c|}
\hline \multirow[t]{2}{*}{ Fungus } & \multicolumn{3}{|c|}{ Type of soil } & \multicolumn{3}{|c|}{ Type of straw } & \multicolumn{3}{|c|}{ Interaction soil/straw } \\
\hline & $\begin{array}{c}\text { exp. I } \\
:\end{array}$ & exp. II & $\begin{array}{l}\text { con- } \\
\text { cord- } \\
\text { ance }\end{array}$ & exp. I & exp. II & $\begin{array}{l}\text { con- } \\
\text { cord- } \\
\text { ance }\end{array}$ & $\exp .1$ & exp. II & $\begin{array}{l}\text { con- } \\
\text { cord- } \\
\text { ance }\end{array}$ \\
\hline Fusarium & $x \times$ & $x$ & - & $x \times$ & $x \times$ & + & $x \times$ & $x \times$ & 0 \\
\hline Pythium & $x \times$ & & & $x \times$ & $x \times$ & - & & & \\
\hline Mucoraceae & & & & $x \times$ & $x \times$ & + & & & \\
\hline Trichoderma & $x \times$ & $x \times$ & + & $x \times$ & $x$ & + & $x \times$ & & \\
\hline Chaetomium & & $x \times$ & & & $x \times$ & & & $x \times$ & \\
\hline $\begin{array}{c}\text { Stysanus }+ \\
\text { Trichurus }\end{array}$ & $x$ & $x \times$ & 0 & $x$ & $x \times$ & - & & & \\
\hline Petriella & $x \times$ & $x$ & + & $x \times$ & & & $x \times$ & & \\
\hline Gliocladium & $x$ & $x \times$ & 0 & $x$ & $x \times$ & 0 & & $x$ & \\
\hline Ophiobolus & & & & $x \times$ & $x \times$ & + & & & \\
\hline $\begin{array}{l}x=\text { significa } \\
x \times=\text { signif } \\
+=\text { complet } \\
-=\text { no conc } \\
0=\text { almost }\end{array}$ & $\begin{array}{l}\text { at } 5 \% \\
\text { int at } 1 \% \\
\text { concorde } \\
\text { dance } \\
\text { acordant }\end{array}$ & & & & & & & & \\
\hline
\end{tabular}


properties in both experiments, is the only fungus for which antagonism could be expected with good reason.

It should be realized that each technique has its limitations. With any method only part of the organisms present in the soil can be isolated. Thus, also the present experiment provided conditions only suitable for the isolation of a small part of the soil microflora. Moreover, the identification of fungi up to genera only is very rough. But the results of this experiment give the impression that a more precise determination would not have given more useful results. The disagreement of many effects in both experiments suggests that differences in numbers of fungi between antagonistic and normal soil, even when statistically significant, have nothing to do with actual antagonism. Also, the preference of particular fungi for fresh or precolonized straws proved not to be consistent between experiments. The only effect which is clearly established as a result of this experiment is the well known poor colonization of precolonized material by other fungi. In general less fungi are found on $L O$ than on DO and NO straws (BARTON, 1961; BRUEHL \& LAI, 1966; LAI \& BRUEHL, 1967).

\subsection{Infection of wheat with Ophiobolus inoculum to which other fungi have been added}

To test whether the results of the experiment just described (7.2) bear any relation to depression of Ophiobolus attacks on wheat, some of the fungi isolated were added to Ophiobolus inoculum some time before inoculating wheat.

\subsubsection{Materials and methods}

Erlenmeyer flasks $(300 \mathrm{ml})$ were inoculated with Ophiobolus and incubated for 17 days. Then $20 \mathrm{ml}$ of a shake culture of each of the following fungi (one isolate per species or genus) on potato dextrose was added to 6 flasks each: Chaetomium sp., Didymella exitialis, Fusarium culmorum, Gliocladium cf. catenulatum, Mucor sp., Ophiobolus graminis, Petriella sordida and Stysanus sp. D. exitialis was not isolated from straws in the experiment of 7.2 ; a culture was received from the Centraal Bureau voor Schimmelcultures (CBS) (National Fungal Collection) at Baarn. This fungus was included since SIEGLE (1961) described it as a hyperparasite of Ophiobolus. After a period of 9,16 and 23 days of mixed culture, 4 wooden boxes with fresh $T 69$ soil at each time were mixed with the contents of 2 flasks of each treatment. The time since superinoculation is indicated by first, second and third series, respectively; the inoculum by the generic name of the superinoculated fungus. Gliocladium, Fusarium, Chaetomium, Mucor and Stysanus were able to establish themselves on the Ophiobohis inoculum but with decreasing ability in the given order. Petriella and Didymella did not grow visibly but their growth in shake culture was already very restricted. Through lack of greenhouse facilities an unconditioned greenhouse had to be used, in which temperature fluctuated widely; it was often rather low $\left(10^{\circ} \mathrm{C}\right)$. 


\subsubsection{Results}

The average disease indexes of the 4 boxes of each treatment are given in table 28 . Figure 12 is a graphical representation with 0.4 and 1.0 subtracted from the disease indexes of second and third series, respectively, to give a horizontal line for the disease index for Ophiobolus. In the first series the disease index after inoculation with Chaetomium is appreciably, though not significantly, higher than after inoculation with Ophiobolus. Fusarium and Mucor depress the disease index, the latter significantly $(\mathrm{P}=5 \%$ ). In the second series Fusarium and Mucor behave similarly, though the depression is not significant; Gliocladium also induces a considerable depression. In the third series Chaetomium, Gliocladium and Mucor depress the disease index significantly.

\subsubsection{Discussion}

The present experiment can be considered as a modification of experiments described by many workers (BROADFOOT, 1933a; BRÖMMELHUES, 1935; FLÜCK, 1955; LAL, 1939; SANFORD \& BroADFOOT, 1931; SIEGLE, 1961; SLAGG \& Fellows, 1947; ZoGG, 1950; ZoGG, 1951). Most of them studied the effect of mixing soil with Ophiobolus and one or more other fungi or bacteria simultaneously, or of inoculation of the soil with a mixed culture of Ophiobolus and another organism. The influence of culture filtrates on severity of disease in Ophiobolus-inoculated wheat was also tested by many of these authors. The soil used generally had been sterilized before. SLAGG \& FelLows (1947) inoculated fungi into a medium on which Ophiobolus had already been established and sowed wheat on it 14 days later. Despite these differences in method the general conclusion has always been the same: some organisms reduce Ophiobolus

Table 28. Effect of superinoculation of Ophiobolus inoculum with various other fungi on the severity of disease in wheat as measured by disease index. Superinoculation at 9,16 , and 23 days before inoculation of the wheat.

\begin{tabular}{llll}
\hline Fungus & \multicolumn{2}{l}{ Days before inoculation of the wheat } \\
\cline { 2 - 4 } & 9 & 16 & 23 \\
Ophiobolus & 3.0 & 3.4 & 4.0 \\
Chaetomium & 3.7 & 2.8 & $2.3 \times$ \\
Didymella & 3.4 & 2.8 & 3.8 \\
Fusarium & 2.1 & 2.3 & 4.0 \\
Gliocladium & 3.1 & 2.6 & $2.5 \mathrm{x}$ \\
Mucor & $1.8 \mathrm{x}$ & 2.5 & $2.1 \times$ \\
Petriella & 3.2 & 3.0 & 3.6 \\
Stysanus & 3.5 & 3.1 & 4.4 \\
\hline
\end{tabular}

$x=$ significantly differing from Ophiobolus $(P=5 \%)$. Tested with the 'Studentized range' of PEARsON \& HARTLEY (1943-6). 
attack and some do not. But the fungi may behave quite different in the different experiments. The experiments do not give much information about the mechanism of the antagonism. This can be illustrated very well with examples from the experiment just described. The decrease in disease index caused by Gliocladium and Chaetomium, which is not found in the first series, seems to exist in the second, and is significant in the third, might be explained as the consequence of a progressive decomposition of Ophiobolus mycelium in the inoculum. As to Gliocladium this would be consistent with the results of 7.2. The effect of Mucor cannot be explained in this way, however. Mucoraceae are not known as producers of antibiotics or as potent saprophytic competitors under normal soil conditions. However, they can grow rapidly and frequently colonize roots of young cereals and grasses (ČATSKÁ, MACURA \& VÁGNEROVA, 1960; GADGIL, 1965). Therefore it seems most likely that a very rapid expansion of Mucor on the wheat roots has prevented the development of Ophiobolus. In the literature, depression of Ophiobolus by Mucoraceae (SKIPSNA, 1963) but also the reverse (BRÖMmELHUES, 1935) is reported. Just like Mucoraceae, some Fusarium spp. are primary colonizers of young cereal roots (GADGIL, 1965; PARKINSON, TAYLOR \& Pearson, 1963). Fusarium behaves like Mucor in the first and second series; no explanation can be offered for its inactivity in the third series.

Such diverse mechanisms as discussed here might all lead to depression of Ophiobolus. Considering the results of 5.3.2 and 7.1, it is still doubtful whether any of the fungi studied are important in a specific antagonism to Ophiobolus. Only Gliocladium spp. may be supposed with good reason to do so.

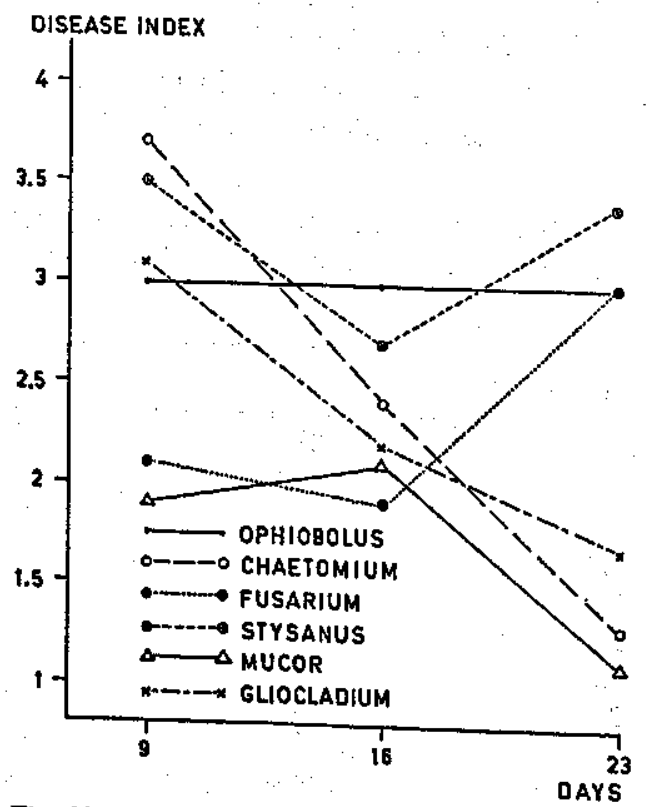

Fig. 12. Effect of superinoculation of Ophiobolus inoculum with other fungt on severity of disease in wheat. Superinoculation at 9,16, or 23 days before inoculation of the wheat. Adjusted to get a straight
line for Ophiobolus alone. 


\subsection{Some remarks on soil ecology and the determination of the antagonistic microflora}

Two approaches might be followed to elucidate antagonism in soil:

1. testing the antagonism of soil isolates;

2. determining differences in the composition of the microflora of antagonistic and non-antagonistic soil.

Both approaches are open to fundamental criticism through soil ecology.

1. Testing of antagonism of isolates from soil is mostly performed on agar plates; sometimes the results are checked in vivo (on plants grown in soil) later. Often results then disagree. For instance, BROADFOOT (1933b) already reported the discrepancy between the results obtained on two agar media when testing the antagonism of fungi and bacteria to Ophiobolus. The agreement was even less when antagonism in vitro (on agar) was compared with that in vivo: no correlation existed. The same has been found by LAL (1939) and ZoGG (1951). HADDEN (1965-6), working with Pythium root rot of sugar-cane, failed to find a close correlation between the production of antibiotics by actinomycetes in vitro and disease suppression by these actinomycetes in the field. AUBE (1967) found about the same for Verticillium wilt of lucerne. The importance of composition of the culture medium is also well known from the industrial production of antibiotics. Therefore not much value can be attached to testing of antagonistic activity in vitro (7.1). The discrepancy described may safely be regarded as a common feature of present techniques, though positive results occur. The necessity of caution in generalizing results obtained in vitro has been realized by many authors (HUBER \& WATSON, 1966; LOCHHEAD \& LANDERKIN, 1949; MANGAN, 1967; PARK, 1956; SCHROTH \& HILdEBRAND, 1964; VIENNOT-BoURGIN, 1964; WiNTER, 1940; WINTER, 1944; WOOD \& TVEIT, 1955).

Even testing of possible antagonists in vivo does not necessarily lead to conclusions which also apply to field conditions. In all experiments of this type fungi are introduced into soil which is in special condition. If the fungus tested is not normally present in this soil, this already indicates that conditions are not suitable for it. Thus, a fungus which is a strong antagonist in its own habitat might completely lack antagonistic activity in experimental conditions. Also, the addition of organic matter simultaneously with inoculum, or the use of sterilized soil for the experiment, might result in antagonism which does not exist under normal conditions.

2. Very little literature about differences in microflora between antagonistic and normal soil is present. However, many reports about the influence of different crop rotations on the microflora are known and these already give some indication about the problems which can be expected. (The accumulation of pathogens of a crop after growing this crop will not be considered).

The microflora of a soil depends on the type of soil, the climate, the root exudates of the crop grown and the type of organic material left on and in the soil after harvest. Normally, rotation experiments are performed within a limited area, in which soil and climate are almost even. 
Most literature mentions differences in microflora after different rotations (HERR, 1957; JoOste, 1966; Kommedahl \& Brock, 1954; Menon \& Williams, 1957; Mishustin \& TEPPER, 1963; PAHARIA, 1955-6), but sometimes differences are small or absent (Cassini, Cassini \& Massenot, 1966; Domsch \& Gams, 1966; Gams \& Domsch, 1966; Gams \& Domsch, 1967). Gams \& Domsch (1966, 1967), who explicitly stated that they looked at the same rotations on different sites, found the influence of the sites to be much more important than that of the crop rotation. This is not surprising, since the influence of root exudates and crop residues is limited. The composition of crop residues generally falls within a very restricted chemical range. GaMs (1967) reported that differences between varieties of the same cereal species in root exudates are sometimes larger than between species, oats excluded. Moreover, MISHRA (1967) found highly significant differences in the rhizoplane microflora of different plant species, but these differences were already smaller in the rhizosphere. Therefore root exudates cannot be supposed to greatly influence total soil microflora.

Concluding, it can be said that no clear relation between crop, soil, and soil microflora has yet been established. Similar difficulties especially in the unknown influence of soil type can be expected when differences are sought between the composition of an antagonistic and a non-antagonistic microflora.

But sometimes differences have been demonstrated. VAN EMDEN (1967) showed that the soil fungal flora of a field, in which potatoes were liable to Rhizoctonia disease, differed from that of a very similar field which, however, had protecting characteristics. These differences could even be related to antagonistic capacity of the fungi in vitro. Another example of success in this field is the bacterial balance index (WEST \& LOCHHEAD, 1940) which is reported to be very well correlated with the incidence of strawberry root rot. But SCHMIDT (1962), comparing healthy and diseased patches for the number of actinomycetes and their antagonism in vitro to Ophiobolus, got much less clear results; EHLE (1965) completely failed to find such differences. StUMBo, Gainey \& ClarK (1942) did not find differences in numbers of microorganisms within physiological groups when comparing soil of healthy and diseased patches.

The interesting experiments of VAN EMDEN (1967) form one of the exceptional cases in which the results of tests in vitro, undertaken to examine the significance of differences found, agree with the observations in vivo. The method used by EHLB (1965) and ScHmidT (1962) suffers from the objections discussed under approach 1.

Tracing the organisms responsible for the decline of Ophiobolus has failed. An understanding of soil ecology makes clear that the techniques used so far are unsuitable for this purpose. At best an indication might be obtained of effective organisms in a special case. 


\section{Further analysis of decline}

The critical consideration of soil ecological problems (chapter 7) has revealed that estimation and explanation of the antagonism of a soil by determining its microflora is still out of reach. Another way of learning something about the mechanism of decline might be the use of laboratory techniques which measure properties correlated with decline. The value of such methods is also limited by soil ecological phenomena. This can be easily demonstrated by the results of an experiment in which a technique was used which was not at all related to natural conditions (8.1). Using techniques in better agreement with natural conditions (8.2), it is possible to get quantitative information on three important aspects of antagonism:

1. antagonism to Ophiobolus during its saprophytic phase;

2. antagonism to Ophiobolus during its parasitic phase;

3. the influence of environmental temperature on antagonism.

This information will contribute to the understanding of decline of Ophiobolus (8.3).

\subsection{Determination of the antagonism to Ophiobolus under artificial conditions}

If antagonism of a soil could be estimated by the competition between $O$ phiobolus and soil organisms as measured on agar media, this method would quickly and easily yield results. Therefore, despite the criticism of such methods, I tried to find a correlation between the known antagonism of a soil and the growth inhibition of $O$ phiobolus on agar induced by the soil microflora. Some of the standard methods based upon this principle were tried, namely:

a. the method described by WASTIE (1961) to assess the competitive saprophytic ability of a fungus;

b. the method of ReINMUTH \& SEIDEL (1966);

c. the three-layer method of HeRR (1959) modified by EHLE $(1965,1966 b)$.

The first two methods are based upon the same principle: suppression of growth of a fungus growing upon cellophane overlying agar, when the agar has been inoculated with unsterilized soil before placing the cellophane on the agar. The third method has been devised to estimate the number of antagonistic actinomycetes in a soil and their respective degrees of antagonism to the test fungus. Trials with this method during the present investigations, were unsuccessful owing to the overgrowing of Ophiobolus by bacteria. The method of WASTIE was most extensively used. Some of the results will be presented here. 


\subsubsection{Materials and methods}

Soil was placed on agar in a Petri dish as described by WASTIE (1961) at 4 points situated at the greatest possible distance from each other and from the rim of the dish. After various times of incubation $(0-48 \mathrm{~h})$ at a favourable temperature the agar was covered with a cellophane film 6 and the test fungus was inoculated upon the cellophane by means of agar disks just over the four points where soil had been placed. The growth of the fungus was compared with a control without soil.

Since Ophiobolus is very easily suppressed by other micro-organisms, in the present experiment the cellophane and Ophiobolus disks were placed in position directly after application of the soil.

Two experiments were performed with differently treated S 6 soil, namely LO soil in its first, second, fourth and seventh cycle and DO and NO soils in their first cycle, indicated as $1 \times$ LO, $2 \times$ LO, $4 \times$ LO, $7 \times$ LO, DO and NO, respectively. The first experiment was performed when the (last) treatment of the soil had occurred $11 / 2$ month ago, the second 1 month later. A control without soil was included. To gain information about the group of organisms involved, different agar media were used: PDA, PDA + 50 p.p.m. Terramycin (PDA + T); broth agar (BA); cellulose agar (CA) according to WITKAMP (1960); CA + 50 p.p.m. Terramycin $(\mathrm{CA}+\mathrm{T}$ ); Conn agar (JoHNson et al., 1959) and soil extract agar (SEA) according to LOCHHEAD (JoHNSON et al., 1959). The SEA had been slightly adapted by using equal amounts of soil extract and tap water. PDA and BA are excellent growth media for bacteria; PDA and PDA + T support vigorous growth of fungi; the other media offer poor conditions for growth and are adapted to special groups of organisms: $\mathrm{CA}$ and $\mathrm{CA}+\mathrm{T}$ to cellulose decomposers; ConnA to actinomycetes; SEA to bacteria and actinomycetes. The Petri dishes, 5 per treatment, were incubated at $23^{\circ} \mathrm{C}$. After 3 to 7 days the diameters of the colonies of Ophiobolus were measured. The diameter of the inoculum disk $(6 \mathrm{~mm})$ was subtracted.

In a third experiment 4 soils were compared: T 69 in its fourth LO cycle; T 69 in its fourth DO cycle; $T 69$ stored in the open air for $11 / 2$ year, during which time it was kept free from plant growth; $T 71$ subsoil clay. These soils are indicated as LO, DO, T 69 and T 71, respectively. A non-inoculated control was also present. PDA, PDA + T, SEA and cherry agar (indicated as CHA) were used. The Petri dishes were incubated at $10^{\circ}, 17^{\circ}$ and $23^{\circ} \mathrm{C}$. Measuring the diameters of Ophiobolus colonies took place after 3 and 5 days incubation at $17^{\circ}$ and $23^{\circ}$ and after a longer time, up to 14 days, when incubated at $10^{\circ} \mathrm{C}$. The further design was equal to that of the first experiments.

In a fourth experiment various fungi instead of soil were inoculated upon PDA $+T$.

Cellophane was supplied by AKU. 


\subsubsection{Results and discussion}

First and second experiment: The average diameters of the Ophiobolus colonies are given in table 29. At the second date of assessment, some dishes were too overgrown to allow measurement of $O$ phiobolus (see the dashes in the table). The controls sometimes got infected with a persistent bacteria which can explain the scanty growth of

Table 29. Increase in diameter (in mm) of colonies of Ophlobolus on cellophane overlying different agar media on which different soils had been placed.

\begin{tabular}{|c|c|c|c|c|c|c|c|c|c|c|c|c|}
\hline \multirow[b]{2}{*}{ 嘼 } & \multirow[b]{2}{*}{ 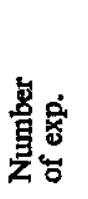 } & \multirow[b]{2}{*}{ 密 } & \multicolumn{7}{|c|}{ Soil } & \multicolumn{2}{|c|}{ Average } & \multirow{2}{*}{$\begin{array}{l}\Delta \\
\text { (for } \\
\text { exp. } \\
\text { I+II) }\end{array}$} \\
\hline & & & 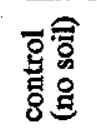 & No & DO & $1 \times L O$ & $2 \times 10$ & $4 \times 10$ & $7 \times 10$ & 它总 & 总 & \\
\hline \multirow[t]{4}{*}{ PDA } & I & 4 & 12.4 & 6.7 & 3.9 & 5.1 & 0.3 & 0.7 & 2.6 & 4.5 & 3.2 & \\
\hline & & 6 & 16.2 & 7.2 & 3.7 & 5.9 & 0.3 & 0.6 & 2.9 & 5.3 & 3.4 & \\
\hline & II & 3 & 10.9 & 9.3 & 7.4 & 7.8 & 2.5 & 2.9 & 3.4 & 6.3 & 5.6 & \\
\hline & & 5 & 13.3 & 9.6 & 8.1 & 8.1 & 3.1 & 3.4 & 4.0 & 7.1 & 6.1 & 0.2 \\
\hline \multirow[t]{4}{*}{$\mathbf{P D A}+\mathbf{T}$} & & 3 & 14.9 & 15.5 & 7.5 & 13.7 & 10.5 & 7.6 & 4.0 & $9.7^{2}$ & $8.7^{2}$ & \\
\hline & & 6 & 33.5 & - & 7.6 & 14.2 & 10.7 & 7.9 & 4.3 & 13.0 & 8.9 & \\
\hline & II & 4 & 32.8 & 25.2 & 16.3 & 15.9 & 15.4 & 19.4 & 11.7 & 19.5 & 17.3 & \\
\hline & & 6 & $\geqslant 44$ & 25.2 & 20.4 & 18.2 & 16.7 & 25.1 & 11.9 & 23.1 & 19.6 & 0.6 \\
\hline \multirow[t]{4}{*}{ BA } & I & 3 & 8.9 & 9.5 & 9.1 & 5.1 & 10.8 & 5.6 & 6.6 & 7.9 & 7.8 & \\
\hline & & 6 & 8.6 & 9.7 & 9.2 & 5.6 & 10.8 & 5.6 & 6.7 & 8.0 & 7.9 & \\
\hline & II & 3 & 5.6 & 3.7 & 3.9 & 3.5 & 2.4 & 2.6 & 2.9 & 3.5 & 3.2 & \\
\hline & & 6 & 6.2 & 4.3 & 4.0 & 3.3 & 2.6 & 2.9 & 3.2 & 3.8 & 3.4 & 0.1 \\
\hline \multirow[t]{4}{*}{$\mathrm{CA}$} & I & 3 & 6.6 & 5.6 & 3.9 & 3.3 & 3.4 & 18.8 & 9.0 & 7.2 & 7.3 & \\
\hline & & 6 & 5.4 & 10.1 & 8.4 & 6.9 & 6.4 & 22.8 & 14.5 & 10.6 & 11.5 & \\
\hline & II & 4 & 7.9 & 6.2 & 6.0 & 6.7 & 7.6 & 2.5 & 11.6 & $6.6^{2}$ & $6.6^{2}$ & \\
\hline & & 7 & - & 7.1 & 8.3 & 8.2 & 9.9 & - & - & 8.4 & 8.4 & 1.0 \\
\hline \multirow{4}{*}{$\mathbf{C A}+\mathbf{T}$} & I & 4 & 10.9 & 13.4 & 17.6 & 9.8 & 14.7 & 20.7 & 12.8 & $14.7^{2}$ & $15.7^{2}$ & \\
\hline & & 7 & 12.8 & - & 21.4 & 11.6 & 20.4 & 26.2 & - & 18.5 & 19.9 & \\
\hline & II & 4 & 23.7 & 10.0 & 32.7 & 34.9 & 22.4 & 34.5 & 32.0 & 27.2 & 27.8 & \\
\hline & & - & - & - & - & - & - & - & - & - & - & 1.4 \\
\hline \multirow[t]{4}{*}{ ConnA } & I & 4 & 4.3 & 5.2 & 11.7 & 7.0 & 13.2 & 6.3 & 8.3 & $7.8^{2}$ & $8.7^{2}$ & \\
\hline & & 6 & 8.4 & - & - & 16.3 & 20.7 & 14.0 & 15.1 & 14.9 & 16.5 & \\
\hline & II & 3 & 1.9 & 1.8 & 2.3 & 1.7 & 1.9 & 2.5 & 1.0 & 1.9 & 1.9 & \\
\hline & & 6 & 4.8 & 5.7 & 6.5 & 4.6 & 5.9 & 9.1 & 3.8 & 5.8 & 5.9 & 2.6 \\
\hline \multirow[t]{4}{*}{ SEA } & I & 4 & 13.8 & 7.0 & 5.7 & 2.6 & 5.5 & 13.2 & 3.7 & 7.4 & 6.3 & \\
\hline & & 6 & 36.1 & 16.9 & 13.0 & 10.1 & 17.4 & 27.8 & 9.4 & 18.7 & 15.8 & \\
\hline & II & 3 & 7.1 & 4.8 & 7.0 & 8.8 & 10.4 & 9.3 & 10.4 & 8.3 & 8.5 & \\
\hline & & 5 & 11.8 & 7.9 & 9.6 & 15.4 & 19.4 & 19.5 & 18.3 & 14.6 & 15.0 & 4.0 \\
\hline
\end{tabular}

1 Number of days between inoculation of Ophiobolus on the cellophane and measurement of colony diameter.

${ }^{2}$ Average of soils of which measurements are available at both dates.

$\Delta$ Average daily increase in diameter between the two dates of measurement; calculated for both experiments combined; controls excluded. 
Ophiobolus in some cases. Table 30 gives the rank order of the growth of Ophiobolus, 1 being the best growth and 7 the least. It can be seen that no clear correlation between the antagonism of the soil and the rank order exists. On the rich growth media (PDA, PDA + T, BA) the tendency is for decreasing colony size with increasing antagonism of the soil. On the poor media, however, just the reverse occurs: Ophiobolus grows least with the control and with NO soil. In this group of media results vary too much to yield valuable information. Considering the sum of the rank orders in the group of rich media it is apparent that little or no difference between DO and $\mathrm{LO}$ soils is found. Thus this test is not sensitive for the estimation of decline. However, a big difference is found between NO and DO soil. This will have been caused by a larger activity of the soil microflora as a whole in DO soil. Therefore, the test is suitable to estimate the general activity of soil microflora (reduction; see 5.2.4).

Table 30. Rank of increase in diameter of Ophiobolus colonies of table 29. Situation at second date of measurement, unless series is incomplete at that date.

\begin{tabular}{|c|c|c|c|c|c|c|c|c|c|}
\hline \multirow[t]{2}{*}{ Group } & \multirow[t]{2}{*}{ Medium } & \multirow{2}{*}{$\begin{array}{l}\text { Number } \\
\text { of exp. }\end{array}$} & \multicolumn{7}{|c|}{ Soil } \\
\hline & & & $\begin{array}{l}\text { control } \\
\text { (no soil) }\end{array}$ & NO & DO & $1 \times 20$ & $2 \times 10$ & $4 \times$ LO & $7 \times \mathrm{LO}$ \\
\hline \multirow{10}{*}{$\begin{array}{l}\text { A (rich } \\
\text { media) }\end{array}$} & PDA & I & 1 & 2 & 4 & 3 & 7 & 6 & 5 \\
\hline & & II & 1 & 2 & 4 & 3 & 7 & 6 & 5 \\
\hline & $\mathbf{P D A}+\mathbf{T}$ & I & 2 & 1 & 6 & 3 & 4 & 5 & 7 \\
\hline & & II & 1 & 2 & 4 & 5 & 6 & 3 & 7 \\
\hline & BA & $I$ & 4 & 2 & 3 & 7 & 1 & 6 & 5 \\
\hline & & II & 1 & 2 & 3 & 4 & 7 & 6 & 5 \\
\hline & Sum of & & & & & & & & \\
\hline & group A & I & 7 & 5 & 13 & 13 & 12 & 17 & 17 \\
\hline & & II & 3 & 6 & 11 & 12 & 20 & 15 & 17 \\
\hline & & I + II & 10 & 11 & 24 & 25 & 32 & 32 & 34 \\
\hline \multirow{12}{*}{$\begin{array}{l}\text { B (poor } \\
\text { media) }\end{array}$} & $\mathrm{CA}$ & I & 7 & 3 & 4 & 5 & 6 & 1 & 2 \\
\hline & & II & 2 & 5 & 6 & 4 & 3 & 7 & 1 \\
\hline & $\mathrm{CA}+\mathrm{T}$ & I & 6 & 4 & 2 & 7 & 3 & 1 & 5 \\
\hline & & II & 5 & 7 & 3 & 1 & 6 & 2 & 4 \\
\hline & ConnA & I & 7 & 6 & 2 & 4 & 1 & 5 & 3 \\
\hline & & II & 5 & 4 & 2 & 6 & 3 & 1 & 7 \\
\hline & SEA & $\mathbf{I}$ & 1 & 4 & 5 & 6 & 3 & 2 & 7 \\
\hline & & II & 5 & 7 & 6 & 4 & 2 & 1 & 3 \\
\hline & Sum of & & & & & & & & \\
\hline & group B & I & 21 & 17 & 13 & 22 & 13 & 9 & 17 \\
\hline & & II & 17 & 23 & 17 & 15 & 14 & 11 & 15 \\
\hline & & $\mathbf{I}+\mathbf{I I}$ & 38 & 40 & 30 & 37 & 27 & 20 & 32 \\
\hline
\end{tabular}

$1=$ largest increase

$7=$ smallest increase 
Another important character, correlated with the difference between the two groups of growth media mentioned, is the increase in colony diameter of $O$ phiobolus between 3-4 and 5-7 days after inoculation. This increase is small for the first group of media and large for the second group ( $\Delta$ in table 29 ). Growth of bacteria especially seems to stop Ophiobolus. This again stresses the fact that in this test, growth of Ophiobolus is not primarily checked by the activity of specific antagonists.

In the third experiment (table 31) growth of Ophiobolus on SEA and CHA was poor and this was again accompanied by big variations in diameter as in the foregoing experiments. Also, the differences in average diameter with different types of soil are much smaller on these media than on PDA and PDA $+T$, thus confirming that only on the latter media growth of Ophiobolus stops soon. The results with PDA and $\mathrm{PDA}+\mathrm{T}$ confirm the supposition, discussed under experiments 1 and 2, that the general activity of the soil microflora is more important in this method than its specific antagonistic properties. DO and LO behaved alike in greatly suppressing growth of Ophiobolus. T 69 soil, which may be supposed to possess a microflora with reduced activity through $1 \frac{1}{2}$ year fallow, limited the growth of $O$ phiobolus to a lesser extent. T 71 subsoil clay, which has a still lower microbial activity, had no effect. Temperature during incubation did not influence the reaction of Ophiobolus on different soils.

Furthermore it was proved that the growth of Ophiobolus was the more suppressed,

Table 31. Effect of inoculation of different agar media with various soils (antagonistic soil, and nonantagonistic soils with different microbial activity) on growth of Ophiobolus. Ophiobolus has been placed on cellophane overlying the agar media. Increase in diameter of Ophiobolus colonies (in $\mathrm{mm}$ ) measured after 5 days incubation at $17^{\circ}$ or $23^{\circ} \mathrm{C}$, and after 14 days at $10^{\circ} \mathrm{C}$.

\begin{tabular}{llrrrrr}
\hline Medium & $\begin{array}{l}\text { Temperature } \\
\text { of incubation }\end{array}$ & \multicolumn{5}{c}{ Soil } \\
\cline { 3 - 7 } & & LO & DO & T 69 & T 71 & $\begin{array}{c}\text { Control } \\
\text { (no soil) }\end{array}$ \\
& & & & & & \\
PDA & $10^{\circ}$ & 11.0 & 10.5 & 19.7 & 33.4 & 33.9 \\
& $17^{\circ}$ & 13.2 & 11.4 & 20.4 & 30.8 & 32.3 \\
& $23^{\circ}$ & 11.0 & 11.8 & 20.7 & 28.5 & 40.0 \\
PDA+T & $10^{\circ}$ & & & & & \\
& $17^{\circ}$ & 14.1 & 12.6 & 20.3 & 26.2 & 25.6 \\
& $23^{\circ}$ & 12.7 & 12.6 & 19.2 & 36.9 & 34.7 \\
SEA & $10^{\circ}$ & & & & & \\
& $17^{\circ}$ & 21.4 & 21.9 & 20.6 & 27.8 & 27.0 \\
& $23^{\circ}$ & 23.7 & 15.5 & 14.8 & 22.2 & 20.9 \\
& & 24.5 & 27.0 & 29.6 & 26.9 & 32.6 \\
CHA & $10^{\circ}$ & & & & & \\
& $17^{\circ}$ & 6.9 & 7.0 & 7.2 & 6.0 & 6.9 \\
& $23^{\circ}$ & 13.0 & 9.2 & 11.9 & 14.5 & 12.0 \\
\hline
\end{tabular}


the faster the growth of fungi applied under the cellophane (table 32).

Surveying the present results, the method of WASTIE can be stated to fail in distinguishing antagonistic and non-antagonistic soil. Also the experiments do not give any indication of the group of micro-organisms responsible for the antagonism. The objection to the use of this method for the present purpose, the differentiation between soils differing in antagonistic properties, has already been discussed (7.4).

\subsection{Assessment of the antagonism with methods imitating natural conditions}

\subsubsection{Antagonism to Ophiobolus during its saprophytic phase}

A very good approximation of the survival of Ophiobolus in its saprophytic stage in nature can be obtained by the seedling test (GARRETT, 1938). Therefore this method was used to assess the influence of antagonistic soil upon the rate of breakdown of Ophiobolus.

Materials and methods. The method is described in detail by GARRETT (1938), therefore only the modifications applied are recorded here. Potato dextrose broth $(5 \mathrm{ml})$ and water $(5 \mathrm{ml})$ were added to 55 pieces of straw in $100 \mathrm{ml}$ Erlenmeyer flasks. The flasks were autoclaved twice for $30 \mathrm{~min}$. at $120^{\circ} \mathrm{C}$ with one day interval. After inoculation with Ophiobolus they were incubated at $23^{\circ} \mathrm{C}$ for three weeks. Then the straws were mixed with different soils ( $200 \mathrm{~g}$ dry weight in $370 \mathrm{ml}$ glass tumblers) and incubated for a varying number of weeks at $23^{\circ} \mathrm{C}$. Subsequently they were washed free of adhering soil and planted in sand after a wheat grain had been mounted in each straw. The boxes with the plants were kept in a greenhouse at about $16^{\circ} \mathrm{C}$. After 19-22 days, the roots of all plants were examined microscopically; the percentage plants with Ophiobolus was calculated and a numerical expression of the degree of root attack (see 3.5 ) was given. All treatments were duplicated. In a preliminary

Table 32. Effect of inoculation of agar medium (PDA + 50 p.p.m. Terramycin) with various fungi on growth of Ophiobolus. Ophiobolus has been placed on cellophane overlying the agar medium.

\begin{tabular}{llc}
\hline Fungus inoculated on agar & \multicolumn{2}{c}{ Increase in diameter of Ophiobolus colony (in mm) } \\
\cline { 2 - 3 } & 4 days & 6 days \\
Control (no fungus) & 19.8 & 30.0 \\
Didymella exitialls & 22.9 & 34.0 \\
Petriella sordida & 27.4 & 33.7 \\
Chaetomium sp. & 12.0 & 13.1 \\
Gliocladium cf. catenulatum & 7.7 & 7.8 \\
Stysanus sp. & 5.0 & 6.0 \\
Mucor sp. & 4.3 & 4.3 \\
Fusarium culmorum & 0.8 & 0.9 \\
\end{tabular}


Table 33. Effect of soil type (antagonistic or not) in which straws colonized by Ophiobolus are incubated, on survival of Ophiobolus (seedling test). Percentage seedlings with Ophiobolus after different times of incubation of the straws, and the average degree of root attack of infected plants (between brackets) are recorded.

\begin{tabular}{lrrrrr}
\hline Soil & \multicolumn{5}{c}{ Incubation (weeks) } \\
\cline { 2 - 6 } & \multicolumn{1}{c}{3} & 6 & 12 & \\
& & & & & \\
NO & 98 & $(1.9)$ & $100(2.8)$ & $60(1.2)$ \\
$1 \times$ LO & 100 & $(2.2)$ & $100(3.0)$ & $76(1.9)$ \\
$4 \times$ LO & 91 & $(1.3)$ & $23(1.5)$ & $5(1.0)$ \\
\hline
\end{tabular}

experiment three different soils were used: $\mathrm{S} 6$ in its first cycle as a control (NO); $\mathrm{S} 6$ in its first LO cycle $(1 \times \mathrm{LO})$ and S 6 in its fourth LO cycle $(4 \times \mathrm{LO})$. The experiment started three months after the last treatment of the soil. In a second experiment on a slightly larger scale, the soils used were S 6 NO, $1 \times$ LO, $3 \times$ LO and $5 \times \mathrm{LO}$; there the last treatment had been given $1 \frac{1}{2}$ month before.

Results and discussion. The percentage seedlings carrying Ophiobolus and the average disease indexes of the roots of plants with Ophiobolus are given in tables 33 and 34. The experiments show that Ophiobolus on precolonized material is more quickly broken down in antagonistic than in normal soil. (Soil with more than one LO treatment can be considered antagonistic). In the present experiments 2-3 months are necessary for the complete breakdown of Ophiobolus in antagonistic soil.

The importance of the decomposition of Ophiobolus in its saprophytic stage is demonstrated very well by the effect of early sowing on the experimental field described in 5.2.2. It should be stressed that the quick breakdown of Ophiobolus in antagonistic soil is independent of the decay of organic material in general. DoMsch (1964a) even found a slower decomposition of wheat roots when wheat was grown after wheat than when grown after peas or rape. Thus continuous cereal growing promotes selective breakdown of $O$ phiobolus.

Table 34. Effect of soil type (antagonistic or not) in which straws colonized by Ophiobolus are incubated, on survival of Ophiobolus (seedling test). Percentage seedlings with Ophiobolus after different times of incubation of the straws, and the average degree of root attack of infected plants (between brackets) are recorded.

\begin{tabular}{|c|c|c|c|c|c|c|c|c|}
\hline \multirow[t]{2}{*}{ Soil } & \multicolumn{8}{|c|}{ Incubation (weeks) } \\
\hline & 2 & & 4 & & 8 & & 11 & 15 \\
\hline No & 100 & (2.5) & 100 & (2.2) & 90 & (2.1) & $41 \quad(1.7)$ & $3(1.0)$ \\
\hline $1 \times L O$ & 81 & (2.1) & 69 & $(2.0)$ & 65 & (2.3) & $13(1.0)$ & 0 \\
\hline $3 \times 10$ & 66 & (2.3) & 14 & $(0.8)$ & 39 & (1.7) & 0. & 0 \\
\hline $5 \times 10$ & 74 & $(2.0)$ & 20 & $(0.9)$ & 9 & $(2.0)$ & $\mathbf{0}$ & 0 \\
\hline
\end{tabular}


A seedling test performed by VAN DER WATT (1965, table 3) shows the same trend as the experiments just described. His sample 1 is the only one originating from a heavily diseased wheat field, in which antagonism may have been induced. And, indeed, this is the only sample which gives percentages straws with Ophiobolus considerably differing from 100 (after an incubation of 18 weeks or longer).

A second phenomenon demonstrated in tables 33 and 34 is the close correlation between the percentage plants with Ophiobolus and the severity of root attack. This correlation is independent of the type of soil in which the straws were incubated. A low percentage straws with Ophiobolus after a long period of incubation in NO soil, or after a short period in LO soil in both cases is accompanied by a low degree of root attack of the infected plants. Since the organisms inducing decline of Ophiobolus have had ample opportunity to colonize the straws in LO soil, this again supports the idea that the antagonistic organisms do not function except in their natural habitat. Otherwise a difference between LO and NO soil would have been expected.

\subsubsection{Antagonism to Ophiobolus in its parasitic phase}

During the present investigations decline has always been assessed by mixing Ophiobolus through the soil and by sowing wheat immediately thereafter. This technique was thought to enable the measurement of the antagonism to Ophiobolus in its parasitic.phase. Some objections might be made to this method, since it will take about 5 days before the wheat has germinated and infection of roots by Ophiobolus can take place. In these few days a decrease in infectivity of the inoculum might have occurred, though the results of the seedling test (tables 33 and 34) show the decrease to be negligible even after 2 or 3 weeks. The following experiment was set up to remove all doubts in this respect.

Table 35. Effect of sowing wheat immediately after mixing Ophiobolus inoculum through the soil (treatment A), or planting pregerminated wheat at that time (treatment $B$ ) or 6 days later (treatment C) on the severity of disease in wheat. Disease indexes of both replicates recorded.

\begin{tabular}{|c|c|c|c|c|c|c|c|c|c|c|c|}
\hline \multirow[t]{2}{*}{ Soil } & \multirow[t]{2}{*}{ Treatment } & \multicolumn{10}{|c|}{ Date of assessment (days after start of the experiment) } \\
\hline & & \multicolumn{2}{|c|}{20} & \multicolumn{2}{|c|}{23} & \multicolumn{2}{|c|}{27} & \multicolumn{2}{|c|}{31} & \multicolumn{2}{|c|}{38} \\
\hline \multirow[t]{3}{*}{ antagonistic } & LO, A & 1 & 1 & 1 & $\overline{1.5}$ & $\overline{1.5}$ & 2.5 & $\overrightarrow{2}$ & 3 & 2.5 & 3.5 \\
\hline & LO, B & $\mathbf{0}$ & 0.5 & 0.5 & 0.5 & 1.5 & 2.5 & 2.5 & 3 & 2.5 & 3 \\
\hline & LO, C & 0 & $\mathbf{0}$ & 0.5 & 0.5 & 1 & 1.5 & 1.5 & 2 & 2.5 & 2.5 \\
\hline \multirow[t]{3}{*}{ non-antagonistic } & LO, A & 1 & 1 & 1 & 1.5 & 2 & 2.5 & 3.5 & 4 & 5 & 5 \\
\hline & LO, B & 0.5 & 0.5 & 1 & 1 & 2 & 3 & 3.5 & 4 & 4.5 & 5 \\
\hline & LO, C & $\mathbf{0}$ & 0 & 0.5 & 0.5 & 1.5 & 2 & 3.5 & 4 & 4.5 & 5 \\
\hline \multirow[t]{3}{*}{ non-antagonistic } & NO, A & 0 & 0 & 0 & 0 & 0 & 0 & 0 & 0 & 0 & 0 \\
\hline & $\mathrm{NO}_{2, \mathrm{~B}} \mathrm{~B}$ & 0 & 0 & 0 & 0 & 0 & 0 & 0 & 0 & 0 & 0 \\
\hline & NO, C & 0 & 0 & $\mathbf{0}$ & 0 & 0 & 0 & 0 & 0 & 0 & 0 \\
\hline
\end{tabular}


Ophiobolus was added to boxes with antagonistic or non-antagonistic U 43 soil. Controls did not receive Ophiobolus. In part of the boxes wheat was sown and in others pregerminated wheat was planted. These small plants, with shoots and roots about $2 \mathrm{~cm}$ long, had been germinating upon agar at room temperature for 4 days, which is equivalent to 6 days at greenhouse temperature. Other boxes were planted with pregerminated wheat 6 days later. The disease index of the plants was assessed regularly. The same type of experiment was repeated several times. The results of a representative duplicated experiment are given in table 35 . When assessed very early, the pregerminated wheat had slight advantage over the wheat sown normally. For the pregerminated wheat planted at the same time as the other wheat was sown, this is contrary to expectation, since its roots came into contact with completely fresh inoculum. After a short time all differences disappeared. In contrast to the interpretation of an experiment by SEMENIUK \& HENRY (1960), who do not recognize antagonism in the parasitic phase, our experiments indicate that the saprophytic decomposition of Ophiobolus in so few days as necessary for germination of wheat grains, is negligible. Therefore, the type of experiment generally applied during the present investigation, in which the disease index of wheat, sown immediately after LO addition, was assessed, really gave a measure of the antagonism to Ophiobolus in its parasitic phase.

\subsubsection{The effect of temperature upon the antagonism to Ophiobolus}

From the investigations of HENRY (1932) the effect of temperature in influencing soil antagonism was known. Yet very little attention has been paid to this factor. In my work, for instance, the temperature of the greenhouse was adjusted to $16^{\circ} \mathrm{C}$, being the optimum temperature for infection under non-sterile conditions. But all experiments in the laboratory were incubated at room temperature or at $23^{\circ} \mathrm{C}$. BURGESS \& GRIFFIN (1967) proved the competitive saprophytic ability of several fungi to be markedly influenced by temperature. WARD \& HeNRY (1961) showed that Ophiobolus was less checked in growth by low temperature $\left(10^{\circ} \mathrm{C}\right)$ than some other fungi. Furthermore OKAFOR (1966) reported a strongly reduced activity of actinomycetes, known as potent antagonists, at $10^{\circ} \mathrm{C}$. These publications stimulated investigations on the effect of temperature upon the antagonism to Ophiobolus.

Some information about the effect of temperature upon antagonism to Ophiobolus in its parasitic phase is already known from the work of HENRY (1932). Information about the influence of the temperature upon Ophiobolus in its saprophytic stage is still lacking. The Cambridge test (BUTLER, 1953) seemed appropriate to yield data about this point. If the Cambridge test would indicate a higher competitive saprophytic ability of Ophiobolus at lower temperatures, this would automatically imply a better saprophytic survival of Ophiobolus.

Inoculum of Ophiobolus grown on a maizemeal and sand medium was mixed in different proportions with antagonistic and non-antagonistic $U 43$ soil '(LO soil and DO soil respectively). Per glass tumbler, containing $200 \mathrm{~g}$ (dry weight) of the mixture, 
55 straws, previously autoclaved at $120^{\circ} \mathrm{C}$ with $7 \mathrm{ml}$ water, were applied. After incubation of the tumblers for 4 weeks at $10^{\circ}, 17^{\circ}$ and $23^{\circ} \mathrm{C}$, respectively, seeds were put into the straws and the straws planted in the usual way. The roots were examined microscopically 3 weeks. later and the average results of 2 replicates are illustrated in figure 13. At $10^{\circ} \mathrm{C}$, a temperature which is common in soil during autumn and spring, Ophiobolus competes much better saprophytically than at the higher temperatures. Thus, in practice the competitive saprophytic ability of Ophiobolus might be higher than normally assumed, though it should be considered that competition, as in this test, for fresh organic material does not occur in practice. CoOK \& BRUEHL (1968) even found colonization by Fusarium roseum 'Culmorum' to be very restricted though this fungus is considered a saprophyte. It might be assumed that in the field fungi compete for precolonized material. Whether Ophiobolus can then establish itself is highly doubtful (compare 7.2). Thus, under field conditions the influence of temperature will be smaller than that observed in the above laboratory experiment.

- Specific antagonism of the soil proves to reduce the competitive saprophytic ability of Ophiobolus. At high percentages Ophiobolus inoculum the curves in figure 13 are

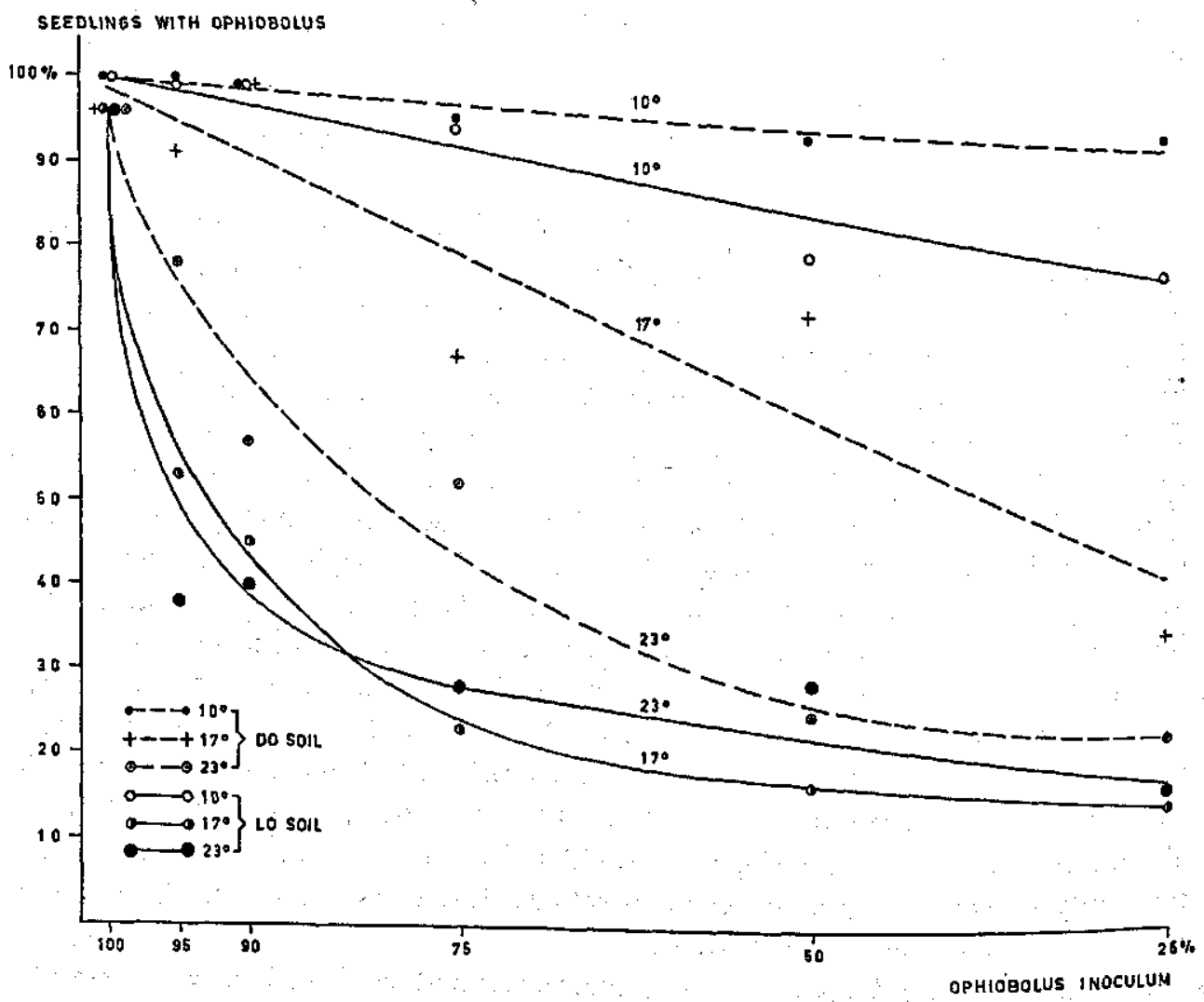

Fig. 13.Effect of percentage Ophiobalus tnoculum, type of soll (antagonistic or not) and temperature of incubation on the colonization of wheat straw by Ophiobolus (Cambridge test). 
steeper for LO than for DO soil, thus demonstrating that a small amount of specific antagonists has a larger effect than of the normal population of a non-antagonistic soil. The difference between LO and DO soil is not influenced by temperature (compare 8.1, experiment 3 ).

\subsection{Decline of Ophiobolus; discussion}

- Non-specific antagonism to Ophiobolus has generally been ascribed to the action of competing micro-organisms which would be most important during the saprophytic stage of Ophiobolus (GrossmanN, 1954; Schmid, 1962). This idea seems reasonable since the saprophytic stage is the weakest link in the life cycle of Ophiobolus. It might also apply to specific antagonism. Indeed, it would be possible to explain all field observations on decline by the higher rate of breakdown of $O$ phiobolus in its saprophytic stage only. LeSTER \& SHIPTON (1967), for instance, assess the degree of antagonism of a soil primarily by the rate of breakdown of Ophiobolus inoculum.

The method of assessment of the antagonism of a soil as used during the present investigations, measures the antagonism during the parasitic phase of Ophiobolus. This by itself could explain most of the field observations; however, the field experiment with different sowing dates (5.2.2) makes clear that antagonism is also very active during the saprophytic phase of Ophiobolus.

The seedling test (8.2.1), performed with soil of which the capacity to antagonize Ophiobolus during its parasitic phase was known, showed that decline during the saprophytic and the parasitic phases of Ophiobolus runs parallel. This indicates that the same antibiotic substance(s) (6.3) inhibit(s) Ophiobolus during both phases. It cannot be stated that decline would be more important in either of the two phases. In the field exceptionally early sowing in antagonistic soil leads to severe attack by Ophiobolus, despite the antagonistic capacity of the soil (5.2.2). When winter wheat is sown year after year at normal times, no whiteheads will occur (5.2.1 and 5.2.2), despite the presence of Ophiobolus in small amounts.

The specialized root parasite Ophiobolus, which needs its superficially growing runner hyphae for the progress of infection, is exposed to the adverse influences of antagonistic micro-organisms even during the most favourable part of its life cycle. Its 'flight into parasitism' does not give complete protection against adverse influences. This might explain the degree of decline obtained with continuous wheat growing. This decline is very pronounced in comparison with other examples of biological control. 


\section{Summary}

After a short introductory chapter on the occurrence of Ophiobolus graminis (take-all disease) in the polders, in chapter 2 the course of the disease and the biology of the fungus are described. The third chapter deals with materials and methods. The following chapters deal with investigations on two aspects of the disease: chapter 4 on the introduction of Ophiobolus into the polders; chapters 5 to 8 on decline of Ophiobolus with continuous cereal growing and the backgrounds of this phenomenon.

The reclamation of the Ysselmeer Polders after drainage follows a fixed pattern. In East Flevoland it was:

reed as a soil cover, gradual reclamation,

rape as a first and wheat as a second crop.

In many fields Ophiobolus already patchily occurs in this wheat crop, mostly at the border of a field. But in field trials with wheat directly after reed, Ophiobolus was more widespread and evenly distributed over the field. Shortly after reclamation Ophiobolus was already present on grasses. The Ophiobolus infection of wheat grown directly after reed was suggested to originate from the reed roots, whereas on wheat grown after rape the grasses at the border of the field were primarily responsible.

The occurrence of Ophiobolus on grasses on an artificial island, $11 / 2$ year after its construction, suggested infection by air-borne ascospores. In the greenhouse, where perithecia-bearing wheat plants of other experiments were present, spontaneous infection of wheat by ascospores occurred regularly, if plants were grown on subsoil clay from East Flevoland. In experiments with wheat and grasses sterility or semisterility of the soil proved to be of paramount importance for successful infection by ascospores. Thus grasses, originating from seed and establishing themselves in the polder directly after drainage, are rapidly infected by Ophiobolus. Reed replacing the grasses picks up the infection, which in turn is passed to wheat after reclamation, and to grasses which establish themselves along roads and ditches.

In the second or third year of continuous cereal growing there is a peak attack of Ophiobolus. Then the incidence of disease declines to a very low level. This could be clearly demonstrated on field trials in the North-East Polder and East Flevoland. In greenhouse trials decline was induced only by soil application of virulent $O p h i o b o l u s$ $(1 \% \mathrm{w} / \mathrm{w}$; fresh weight). Wheat growing itself and application of avirulent $O p h i o b o l u s$ or some other fungi were ineffective. Ophiobolus-induced decline is governed by a 
specific antagonism, as will be shown; by contrast, a non-specific action of the soil microflora is responsible for a less effective antagonism present in every soil. Hereafter antagonism refers to specific antagonism.

By applying Ophiobolus in greenhouse trials once in three months antagonism reaches a maximum within 3-6 months. It is preserved by growing wheat or barley continuously (in the field) or by continued application of Ophiobolus (in the greenhouse). Interruption of continuous cereal growing with another crop for one season, or for two cycles of three months in the greenhouse, considerably decreases the antagonistic capacity of the soil.

The antagonistic capacities of a soil are lost by heating $\left(50^{\circ} \mathrm{C}\right.$ or higher for 30 min.) or application of chemical disinfectants. A mixture of antagonistic and nonantagonistic soil shows an antagonistic capacity in proportion to logarithm concentration of antagonistic soil. Growth of Ophiobolus in vivo is reduced by a sterilized water-extract of antagonistic soil. These three results show that antagonism is governed by antibiotics from soil micro-organisms. (The reduction of growth by the waterextract was measured by the length of runner hyphae on roots of wheat grown in sand. In vitro no effect could be demonstrated. Therefore isolation and identification of the active material had to be suspended).

No differences could be found in the microflora of antagonistic and non-antagonistic soil by isolating fungi by the dilution method and similar techniques, and by using precolonized or clean baits, followed by testing the antagonistic properties of the isolates in vitro and in vivo. None of the isolates could be demonstrated to be of paramount importance in decline.

This failure can be explained as follows. Since antibiotic properties depend on the environment, the actual capacities of an organism cannot be measured in vitro. Conditions of trial even in vivo differ so much from natural conditions that results are not conclusive.

WASTIE's method did not demonstrate any correlation between the antagonism of a series of soils and their effect on growth of Ophiobolus in vitro. But there was a clear effect on survival and colonization in the seedling test and the Cambridge test, in which the wheat plant indicates the presence of Ophiobolus.

The trials described show that antagonistic soil reduces the growth of Ophiobolus in its parasitic stage as well as its survival in the saprophytic stage. 


\section{Samenvatting}

\section{Introductie van Ophiobolus graminis in nieuwe polders en zijn teruggang bij continue graanteelt}

$\mathrm{Na}$ een kort inleidend hoofdstuk over het optreden van Ophiobolus graminis (tarwehalmdoder) in de polders worden in hoofdstuk 2 het ziekteverloop en de levenswijze van de schimmel beschreven. Het derde hoofdstuk bevat een beschrijving van materiaal en methoden. Hierna volgen de experimentele hoofdstukken, die twee aspecten van de ziekte betreffen: hoofdstuk 4 handelt over de introductie van Ophiobolus in de polders; in hoofdstuk 5-8 worden de teruggang van Ophiobolus bij continue graanteelt en de achtergronden van dit verschijnsel behandeld.

De ontginning van de IJsselmeerpolders na het droogvallen verloopt volgens een bepaald patroon. Voor Oostelijk Flevoland was dit:

riet als bodembedekker,

geleidelijke ontginning,

koolzaad als eerste en tarwe als tweede gewas.

In vele velden komt reeds in dit tarwegewas Ophiobolus voor bij enkele groepjes planten, het meest aan de rand van een perceel (fig. 3 en 4; tabel 3). Op proefvelden, waarop tarwe direct na riet werd verbouwd, kwam Ophiobolus echter meer algemeen voor en regelmatig verspreid over het hele veld (fig. 4). Op grassen bleek Ophiobolus al snel na de ontginning algemeen aanwezig (tabel 2). Het kon aannemelijk worden gemaakt dat bij verbouw van tarwe direct na riet de Ophiobolus-infectie van de rietwortels afkomstig is, terwijl bij verbouw na koolzaad de infectie vooral tot stand komt via de grassen aan de rand van het veld.

Uit het voorkomen van Ophiobolus op grassen op een kunstmatig eiland, $1 \frac{1}{2}$ jaar na zijn ontstaan (tabel 4), kon geconcludeerd worden dat de infectie door met de wind verspreide ascosporen moest hebben plaats gevonden. In de kas, waar tarweplanten met peritheciën voor andere proeven aanwezig waren, bleek spontane infectie van tarwe door middel van ascosporen veelvuldig op te treden indien de planten groeiden op uit de ondergrond van Oostelijk Flevoland opgedolven klei. Bij proeven met tarwe en grassen (tabel 6 en 7) bleek steriliteit of semi-steriliteit van de grond van het grootste belang voor deze wijze van infectie. De conclusie uit deze gang van zaken is, dat grassen die zich door middel van zaad direct na het droogvallen in de polder 
vestigen snel geïnfecteerd raken door Ophiobolus. Bij hun verdringing door riet neemt dit de infectie over. Het riet draagt de schimmel weer over aan tarwe en aan grassen die zich na de ontginning vestigen langs wegen en sloten (fig. 7).

Bij continue graanteelt bereikt de aantasting door Ophiobolus een top in het tweede of derde jaar. Daarna loopt de aantasting weer terug tot een zeer laag niveau. Dit verschijnsel staat bekend als 'decline'. Op proefvelden in de Noord-Oost Polder en Oostelijk Flevoland kon dit effect duidelijk worden gedemonstreerd (tabel 8 en 9). In potproeven in de kas kon decline uitsluitend worden gelnduceerd door virulente Ophiobolus aan de grond toe te dienen ( $1 \%$ inoculum op basis van versgewicht). Tarweteelt op zichzelf, het toevoegen van avirulente Ophiobolus of het toevoegen van enige andere schimmels leidden niet. tot decline (tabel 10,11, 13, 14 en 15). De door Ophiobolus geïnduceerde decline berust - zoals nader zal worden aangetoond - op een specifiek antagonisme; dit in tegenstelling tot het minder sterk werkende, normaal in elke grond aanwezige antagonisme, dat berust op een niet-specifieke werking van de bodem-microflora (fig. 8). Onder antagonisme wordt in het volgende het specifieke antagonisme verstaan.

Bij toediening van Ophiobolus elke drie maanden, in potproeven, bereikt het antagonisme in 3 tot 6 maanden een maximum. Het blijft in stand bij continue teelt van tarwe of gerst (te velde) of bij voortgaande toediening van Ophiobolus (in de kas). Onderbreking van continue graanteelt met een ander gewas leidt reeds in én seizoen, of in twee cycli van drie maanden in de kas, tot een vrij sterke daling van het antagonistisch vermogen van de grond (tabel 8, 16 en 17).

Een antagonistische grond verliest zijn antagonistische eigenschappen door verhitting $\left(1 / 2\right.$ uur bij $50^{\circ} \mathrm{C}$ of hoger) of behandeling met chemische grondontsmettingsmiddelen (fig. 9; tabel 19 en 20). Mengen van antagonistische en niet-antagonistische grond verleent aan het mengsel een antagonistisch vermogen evenredig met de logarithme van de concentratie van de antagonistische grond (fig. 10; tabel 21, 22 en 23). Een gesteriliseerd water-extract van antagonistische grond remt de groei van Ophiobolus in vivo (tabel 24 en 25). Deze drie gegevens leidden samen tot de conclusie dat het antagonisme berust op antibioticumproductie door micro-organismen in de grond. (De remming door het water-extract werd gemeten aan de lengte van de 'runner hyphae' op de wortels van tarwe gekweekt in zand. In vitro kon geen remming worden aangetoond. Hierdoor moest voorlopig worden afgezien van het isoleren en identificeren van de stof.)

Isolatie van een aantal schimmels uit antagonistische en niet-antagonistische grond, zowel met de verdunningsmethode en andere vergelijkbare methodes, als met behulp van al dan niet tevoren door Ophiobolus gekoloniseerde 'baits', en toetsing van hun antagonistisch vermogen in vitro en in vivo leidden niet tot resultaat: verschillen in de samenstelling van de microflora van antagonistische en niet-antagonistische grond werden op deze wijze niet gevonden. Van geen der geïsoleerde organismen kan op grond van de experimenten worden verondersteld dat het een essentiële rol speelt bij het tot stand komen van decline. 
Voor dit falen is de volgende verklaring te geven. Daar antibiotische eigenschappen sterk afhankelijk zijn van het milieu waarin een micro-organisme zich bevindt, is het niet mogelijk in vitro een betrouwbaar beeld te krijgen van de werkelijke rol van zo'n organisme. Zelfs in vivo zijn de proefomstandigheden steeds zo verschillend van het natuurlijke milieu, dat conclusies moeilijk zijn te trekken.

Pogingen een correlatie te vinden tussen de graad van antagonisme van een reeks gronden en de beïnvloeding door deze gronden van de groei van Ophiobolus in vitro, met de methode WaSTiE, bleven zonder resultaat (tabel 29, 30 en 31). Met de 'seedling test' (tabel 33 en 34) en de 'Cambridge test' (fig. 13), waarbij de tarweplant optreedt als indicator voor de aanwezigheid van Ophiobolus, werd wél een duidelijke beïnvloeding van het vermogen van Ophiobolus tot overleven, respectievelijk koloniseren in het saprofytische stadium gevonden.

Uit de beschreven experimenten blijkt dat de groei van Ophiobolus in het parasitaire stadium en zijn overleven in het saprofytische stadium beide belemmerd worden in antagonistische grond. 


\section{Acknowledgments}

I am greatly indebted to Prof. Dr A. J. P. Oort, Director at the Laboratory of Phytopathology, Wageningen Agricultural University, for critical guidance.

Miss Annie van Gelder conscientiously assisted in carrying out the experiments.

The Directorate of the Ysselmeer Polders Development and Settlement Authority provided facilities for experiments in the polders. The late Dr Ir J. J. Jonker, his successor Ir G. J. de Jong, and Messrs L. Zelhorst, S. Kuipers and M. Brandsma were excellent guides in the virgin areas.

Mr M. Keuls advised in some statistical problems.

Mrs M. G. A. J. Derksen-Sanders patiently typed and retyped the manuscript. I acknowledge my debt to all who in any other way contributed to this paper. 


\section{References}

\begin{tabular}{|c|c|c|}
\hline ADAM, D. B. & 1951 & $\begin{array}{l}\text { The control of take-all in wheat after a long period of pasture. } \\
\text { Aust.J. agric. Res. } 2: 273-282 \text {. }\end{array}$ \\
\hline ANGELL, H. R. & 1945 & $\begin{array}{l}\text { Unavailability of plant food and take-all of wheat. J. Coun. } \\
\text { scient. ind. Res. Aust. } 18: 37-46 .\end{array}$ \\
\hline $\begin{array}{l}\text { ANGELL, H. R. and } \\
\text { M. MiLLS }\end{array}$ & 1951 & $\begin{array}{l}\text { Rotation in relation to take-all of wheat. Aust. J. agric. Res. } \\
2: 283-285 \text {. }\end{array}$ \\
\hline ANONYMUS & 1955 & $\begin{array}{l}\text { Wording en opbouw van de Wieringermeer. Geschiedenis van } \\
\text { de ontginning en kolonisatie van de eerste IJsselmeerpolder. }\end{array}$ \\
\hline ANONYMUS & 1966 & Wheat diseases. In: A. Rep. Dep. Agric. N.S.W. 1964-1965: 75. \\
\hline AuBé, C. & 1967 & $\begin{array}{l}\text { Antagonisme des champignons du sol envers Verticillium albo- } \\
\text { atrum R. et B., agent de la flétrissure verticillienne de la } \\
\text { luzerne. Can. J. Microbiol. I3: 227-233. }\end{array}$ \\
\hline BANYER, R. J. & 1966 & $\begin{array}{l}\text { Cereal root diseases and their control. Part II. J. Agric. S. } \\
\text { Aust. 69: 372-376. }\end{array}$ \\
\hline BARTON, $\mathbf{R}$. & 1961 & $\begin{array}{l}\text { Saprophytic activity of Pythium mamillatum in soils. II. Fac- } \\
\text { tors restricting P. mamillatum to pioneer colonization of sub- } \\
\text { strates. Trans. Br. mycol. Soc. } 44 \text { : } 105-118 \text {. }\end{array}$ \\
\hline BOCKMANN, $\mathrm{H}$. & 1955 & $\begin{array}{l}\text { Vorfruchtwirkung und Schwarzbeinigkeit beim Weizen. } Z \text {. } \\
\text { PflKrankh. PflPath. PflSchutz 62: 533-539. }\end{array}$ \\
\hline BOCKMANN, $\mathbf{H}$. & 1963 & $\begin{array}{l}\text { Künstliche Freilandinfektionen mit den Erregern der Fuss- und } \\
\text { Ährenkrankheiten des Weizens. II. Die Infektionswirkung und } \\
\text { ihre Beurteilung nach dem Schadbild. NachrBl. Dt. PflSchutz- } \\
\text { dienst, Stuttg. 15: 33-37. }\end{array}$ \\
\hline BOCKMANN, $\mathbf{H}$. & 1965 & $\begin{array}{l}\text { Fruchtfolge und Fusskrankheitsgefahr beim Weizen mit be- } \\
\text { sonderer Berücksichtigung des Anbaues von Grassamen und } \\
\text { grashaltigen Feldfutterkulturen sowie der Stickstoffdüngung. } \\
\text { Review in: Z. PflKrankh. PflPath. PflSchutz } 72: 417 \text {. }\end{array}$ \\
\hline $\begin{array}{l}\text { BOCKMANN, H. and } \\
\text { P. HARTZ }\end{array}$ & 1965 & $\begin{array}{l}\text { Grăseranfälligkeit gegen die Fusskrankheiten. In: Jber. biol. } \\
\text { BundAnst. } L d-u \text {. Forstw. 1964: } 72 \text {. }\end{array}$ \\
\hline Bolam, $\mathbf{P}$. & 1966 & Intensive cereal growing. Agriculture, Lond. 73: 562-567. \\
\hline Boosalus, M. G. & 1964 & Hyperparasitism. A. Rev. Phytopath. 2: 363-376. \\
\hline Bosma, W. A. & 1946 & $\begin{array}{l}\text { De resultaten van enkele proefnemingen. In: Verslag van den } \\
\text { op } 25 \text { februari } 1946 \text { te Marknesse gehouden ontwikkelingsdag } \\
\text { voor de landbouwkundige opzichters. Directie van de Wieringer- } \\
\text { meer (Noordoostpolderwerken), no. 3, Zwolle: 3-19. }\end{array}$ \\
\hline BOSMA, & 1962 & $\begin{array}{l}\text { Het verband tussen de rijping der gronden in de IJsselmeer- } \\
\text { polders en de verbouw van landbouwgewassen. Van Zee Ld 32: } \\
\text { 71-97. }\end{array}$ \\
\hline
\end{tabular}


Brian, P. W.

BROADFOOT, W. C.

1933a

BROADFOOT, W. C.

BRöMMELHUES, $\mathbf{M}$.

Brooks, D. H.

Brooks, D. H.

BRooKs, D. H.

BRUEHL, G. W.

BruehL, G. W. and

$$
\text { P. LAI }
$$

Bullen, E. R.

BURGess, L. W. and

D. M. GRIPFIN

BUTLER, F. C.

BUTLER, F. C.

Butler, F. C.

CASSINI, R.,

R. Cassini and

M. Massenot

ČATSKÁ, V.,

J. MACURA and

K. VÁGNEROVÁ

Chambers, $\mathbf{S}$. $\mathbf{C}$.

Clark, F. E.

Connold, W. Q.
The ecological significance of antibiotic production. In: Williams, R. E. O. and C. C. Spicer (Eds), Microbial ecology, 7th Symp. Soc. gen. Microb., London, 1957. Cambridge University Press: 168-188.

Studies on foot and root rot of wheat. I. Effect of age of the wheat plant upon the development of foot and root rot. Can. J. Res. 8: 483-491.

1933b Studies on foot and root rot of wheat. II. Cultural relationships on solid media of certain micro-organisms in association with Ophiobolus graminis Sacc. Can. J. Res. 8: 545-552.

1935 Die wechselseitige Beeinflussung von Pilzen und die Bedeutung der Pilzkonkurrenz für das Ausmass der Schädigung an Weizen durch Ophiobolus graminis Sacc. Zentbl. Bakt. ParasitKde, Abt. 2, 92: 79-117.

1964 Infection of wheat roots by ascospores of Ophiobolus graminis. Nature, Lond. 203: 203.

1965a Root infection by ascospores of Ophiobolus graminis as a factor in epidemiology of the take-all disease. Trans. Br. mycol. Soc. 48: 237-248.

1965b Wild and cultivated grasses as carriers of the take-all fungus (Ophiobolus graminis). Ann. appl. Biol. 55: 307-316.

1952 Temporary sterilization of soil in the evaluation of root and crown rot losses with wheat and barley under field conditions. Pl. Dis. Reptr 36: 234-237.

1966 Prior-colonization as a factor in the saprophytic survival of several fungi in wheat straw. Phytopathology 56: 766-768.

1963-5 Some problems in intensive cereal production. Outl. Agric. 4: 64-71.

1967 Competitive saprophytic colonization of wheat straw. Ann. appl. Biol. 60: 137-142.

1953 Saprophytic behaviour of some cereal root-rot fungi. I. Saprophytic colonization of wheat straw. Ann. appl. Biol. 40: 284-297.

1959 Saprophytic behaviour of some cereal root-rot fungi. IV. Saprophytic survival in soils of high and low fertility. Ann. appl. Biol. 47: 28-36.

1961 Root and foot rot diseases of wheat. Sci. Bull. Dep. Agric. N.S.W., no. 77; 98 pp.

1966 Mycoflore d'un sol cultivé en blé depuis 1900 à l'école nationale supérieure agronomique de Grignon. Bull. Ass. fr. Etude Sol: 355-365.

1960 Rhizosphere microflora of wheat. III. Fungal flora of wheat rhizosphere. Folia microbiol., Praha 5: 320-330.

1962 Root diseases in wheat on clover ley. Factors under investigation. 1. The role of oats after ley. J. Dep. Agric. West. Aust., Ser, 4, 3: 299-302.

1942 Experiments toward the control of the take-all disease of wheat and the Phymatotrichum root rot of cotton. Tech. Bull. U.S. Dep. Agric., no. 835; 27 pp.

1966 Cereal growing in the South-West. Agriculture, Lond. 73: 437443. 
Cook, R. J. and

G. W. BruehL

Cunningham, P. C.

Cunningham, P. C.

Davies, F. R.

DOMSCH, K. H.

DoMsch, K. H.

Domsch, K. H.

Domsch, K. H.

Domsch, K. H.

DOMSCH, K. H.

Domsch, K. H. and

W. Gams

EHLe, $\mathbf{H}$.

EHLE, $\mathbf{H}$.

EhIs, H.

EMden, J. H. vaN

Feekes, W. and

D. BAKKER

FenLows, H. and

C. H. FICKE

Fellows, H. and

C. H. FICKE

FLÜCK, V.

GADGIL, P. D. 1960a Die Wirkung von Bodenfungiciden. IV. Veränderungen im Spektrum der Bodenpilze. Z. PflKrankh. PflPath. PflSchutz 67: 129-150.

1960b Die Wirkung von Bodenfungiciden. V. Empfindlichkeit von Bodenorganismen in vitro, Z. PflKrankh. PflPath. PflSchutz 67: 211-216.

1964a Abbau von Weizenwurzeln im Boden. In: Jber. biol. BundAnst. Ld- u. Forstw. 1963: 74.

1964b Soil fungicides. A. Rev. Phytopath. 2: 293-320.

1966 Bodenmikrobiologische Untersuchungen in Weizenfeldern. Umschau 66: 671.

1965 Untersuchungen über physikalische und biologische Komponenten der 'Schutzwirkung' des Bodens gegenüber der Ophiobolose des Weizens. Thesis, Giessen; 91 pp.

1966a Einfluss einer Superinfektion mit antagonistischen Actinomyceten auf die Ophiobolose im Gefässversuch. Z. PflKrankh. PflPath. PflSchutz 73: 321-326.

1966b Einfluss der Gründüngung auf die Actinomycetenpopulation des Bodens unter besonderer Berücksichtigung der gegen Ophiobolus graminis Sacc. wirksamen Antagonisten. $Z$. PflKrankh. PflPath. PflSchutz 73: 326-334.

1967. Beschouwing over pathogene bodemschimmels. Meded. Dir. Tuinb. 30: 248-256.

1954 De ontwikkeling van de naturlijke vegetatie in de Noordoostpolder. Van Zee Ld 6: 1-92.

1934 Cereal and forage crop disease investigations. In: 7th Bienn. Rep. Kans. agric. Exp. Sin 1932-4: 94-97.

1939 Soil infestation by Ophiobolus graminis and its spread. $J$. agric. Res. 58: 505-519.

1955 Untersuchungen ïber die Pathogenität von Erregergemischen bei Getreidefusskrankheiten. Phytopath. Z. 23: 177-208.

1965 Distribution of fungi on living roots of certain Gramineae and the effect of root decomposition on soil structure. Pl. Soil 22: 239-259. 
Gams, W.

GAMS, W. and

K. H. DOMSCH

GAMs, W, and

K. H. DOMSCH

GARRETT, S. D.

GARRETT, S. D.

GARRETT, S. D.

GARRETT, S. D.

GARRETT, S. D.

GARRETT, S. D.

GARRETT, S. D. GRRLAGH, M.

GiNDRAT, D.

GlynNe, M. D.

GLYNNE, M. D.

GLYNNE, M. D.

Goring, C. A. I.

Goss, R. L. and

C. J. GoutD

GoTtLIEB, D.

GotTliEs, D. and

P. Siminofr

GottlueB, D.,

P. SnMinofr and

M. M. MARTIN

GREGORY, K. F.,

O. N. ALLEN,

A. J. RIKER and

W. H. PETERSON
1967 Mikroorganismen in der Wurzelregion von Weizen. Mitt. biol. BundAnst. Ld- u. Forstw, no. 123; 77 pp.

1966 Mikrobiologische Analysen von Weizenböden. In: Jber. biol. BundAnst. Ld- u. Forstw. 1965: 77.

1967 Mikrobiologische Analysen von Weizenböden. In: Jber. biol. BundAnst. Ld- u. Forstw. 1966: 76.

1933-4 Factors affecting the severity of take-all. 1. The importance of soil micro-organisms. J. Dep. Agric. S. Aust. 37: 664-674.

1936 Soil conditions and the take-all disease of wheat. Ann, appl. Biol. 23: 667-699.

1938 Soil conditions and the take-all disease of wheat. III. Decomposition of the resting mycelium of Ophiobolus graminis in infected wheat stubble buried in the soil. Ann. appl. Biol. 25: 742-766.

1939 Soil conditions and the take-all disease of wheat. IV. Factors limiting infection by ascospores of Ophiobolus graminis. Ann. appl. Biol. 26: 47-55.

1941 Soil conditions and the take-all disease of wheat. VII. Survival of Ophiobolus graminis on the roots of different grasses. Ann. appl. Biol. 28: 325-332.

1956 Biology of root-infecting fungi. Cambridge University Press; 293 pp.

1966 Spores as propagules of disease. Colston Pap. 18: 309-319.

1966 A perspex box for microscopic observation of living roots. Neth. J. Pl. Path. 72: 248-249.

1966 Etude de la formation des périthèces de Gaeumannomyces graminis (Sacc.) von Arx et Olivier en milieu artificiel et mise au point d'une technique d'immersion des cultures pour leur formation induite. Bull. Soc. bot. suisse 76: 157-175.

1935 Incidence of take-all on wheat and barley on experimental plots at Woburn. Ann. appl. Biol. 22: 225-235.

1963 Report to the wheat industry research council on a tour of wheat research centres in Australia during May, June and July, 1963; 11 pp. (mimeographed).

1965 Crop sequence in relation to soil-borne pathogens. In: Baker, K. F. and W. C. Snyder (Eds), Ecology of soil-borne plant pathogens. University of California Press, Berkeley: 423-435.

1967 Physical aspects of soil in relation to the action of soil fungicides. A. Rev. Phytopath. 5: 285-318.

1967 Some interrelationships between fertility levels and Ophiobolus patch disease in turfgrasses. Agron. J. 59: 149-151.

1957-8 Take-all of wheat in Chile. Pl. Prot. Bull. F.A.O. 6: 20-21. 1952 The production and role of antibiotics in the soil. II. Chloromycetin. Phytopathology 42: 91-97.

1952 The production and role of antibiotics in soil. IV. Actidione and clavacin. Phytopathology 42: 493-496.

1952 Antibiotics as agents for the control of certain damping-off fungi. Am. J. Bot. 39: 405-415. 
GREGORY, P. H. and

D. R. HENDEN '

GREGORY, P. H. and

O. J. Stedman

Grossbard, E.

Grossmann, F.

HADDEN, C. H.

HARLEY, J. L. and J. S. WAID

Heard, A. J.

Henry, A. W.

HERR, L. J.

HerR, I. J.

Hessayon, D. G.

Hirst, J. M.

HURer, D. M. and

R. D. WATSON

Hutshoff, A. J. A. JoHNSON, L. F., E. A. CurL, J. H. BoND and

H. A. Fribourg

JONES, $P$.

JONKER, J. J.

Jooste, W. J.

Kalben, I. R. W. von

KIRBY, R. S.

KLAPP, E.

Koblet, R.

KOMMEDAHL, $T$, and

T. D. BROCK

KREUTZER, W. A.
Seasonal occurrence of airborne Ophiobolus graminis ascospores. In: Rep. Rothamsted exp. Stn for 1966: 134-135.

Spore dispersal in Ophiobolus graminis and other fungi of cereal foot rots. Trans. Br. mycol. Soc. 41: 449-456.

Antibiotics and microbial antagonism in plant pathology. Endeavour 10: 145-150.

Das saprophytische und parasitische Wachstum von Ophiobolus graminis Sacc. unter dem Einfluss verschiedener Fruchtfolgepflanzen und -massnahmen. Phytopath. Z. 22: 35-70.

Studies on actinomycetes in relation to Pythium root rot of sugar cane and corn. Diss. Abstr. 26: 4162.

A method of studying active mycelia on living roots and other surfaces in the soil. Trans. Br. mycol. Soc. 38: 104-118.

Eyespot in wheat after four-course rotations and 31/2-year leys. Ann. appl. Biol. 55: 115-122.

Influence of soil temperature and soil sterilization on the reaction of wheat seedlings to Ophiobolus graminis Sacc. Can. J. Res. 7: 198-203.

Soil mycoflora associated with continuous cropping of corn, oats, and wheat. Ohio J. Sci. 57; 203-211.

A method of assaying soils for numbers of actinomycetes antagonistic to fungal pathogens. Phytopathology 49: 270-273. 'Double-action' of trichothecin and its production in soil. Nature, Lond. 168: 998-999.

Dispersal of soil microorganisms. In: Baker, K. F. and W. C. Snyder (Eds), Ecology of soil-borne plant pathogens. University of California Press, Berkeley: 69-81.

How valid is the agar plate inhibition test for determining antagonism between soil microorganisms. Phytopathology 56: 882.

Root pruning and yield of maize. Neth. J.Pl. Path. 71: 152-156. Methods for studying soil microflora-plant disease relationships. Burgess Publishing Comp., Minneapolis; 178 pp.

Cereals on the chalk. Agriculture, Lond. 74: 2-5.

Bewortelingsonderzoek en ondergrondbewerking in de Noordoostpolder. Van Zee Ld 25: 1-164.

The effect of different crop sequences on the rhizosphere fungi of wheat. S. Afr. J. agric. Sci. 9: 127-135.

Der Einfluss von Stallmistvergärung und Strohdüngung auf die Fusskrankheiten des Weizens. Thesis, Kiel; 35 pp.

The take-all disease of cereals and grasses. Phytopathology 12: 66-88.

Lehrbuch des Acker- und Pflanzenbaues. 5th ed., Parey, Berlin; 503 pp.

Pflanzenhygienische Erfordernisse bei der Aufstellung der Fruchtfolge. Die Grüne 92: 555-562.

Studies on the relationship of soil mycofora to disease incidence. Phytopathology 44: 57-61.

Selective toxicity of chemicals to soil microorganisms. A. Rev. Phytopath. 1: 101-126. 
KREUTZER, W: A.

LAAR, J. H. J. VAN DE

1931

LAI, P. and

G. W. Bruehl

LAL, A.

LARGE, E. C.

LemaiRe, J. M. and B. JOUAN

LESTER, E. and

P. J. SHIPTON

LEWIS, A. H., J. Procter and

A. E. M. HoOD

LOCHHEAD, A. G. and G. B. LANDERKIN

Louw, H. A.

Ludwig, R. A. and

A. W. HENRY

Mangan, A.

Mangan, A. '

MAURER, C. L. and

R. BAKER

McNamara, H. C.,

D. R. Hooton and

D. D. PORTER

Menon, S. K. and

L. E. Wirliams

MENZIES, J. D.

Mishra, R. R.

Mishustin, E. N. and

E. Z. TEPPER
1965 The reinfestation of treated soil. In: Baker, K. F. and W. C. Snyder (Eds), Ecology of soil-borne plant pathogens. Univer. sity of California Press, Berkeley: 495-508.

Onderzoekingen over Ophiobolus graminis Sacc. en Ophiobolus herpotrichus (Fr.) Sacc. en over de door deze fungi veroorzaakte ziekten van Triticum vulgare Vill. en andere Gramineae. Thesis, Wageningen; $146 \mathrm{pp}$.

1967 Antagonism among Cephalosporium gramineum, Fusarium culmorum and Trichoderma spp. in wheat straw buried in soil. Phytopathology 57: 1006-1007.

1939 Interaction of soil micro-organisms with Ophiobolus graminis Sacc., the fungus causing the take-all disease of wheat. Ann. appl. Biol. 26: 247-261.

1954 Growth stages in cereals. Illustrations of the Feekes scale. Pl. Path. 3: 128-129.

1966 Modifications microbiologiques entrainées par la mise en culture de sols nouvellement défrichés. Incidences sur l'installation de l'Ophiobolus graminis Sacc. $=$ (Linocarpon cariceti $\mathrm{B}$ et $\mathrm{Br}$ ) et du Streptomyces scabies (Thaxt) Waksman et Henrici. Annls Epiphyt. 17: 313-333.

1967 A technique for studying inhibition of the parasitic activity of Ophiobolus graminis (Sacc.) Sacc. in field sojls. Pl, Path. 16: 121-123.

1960 A comparison of ley and arable farming systems. J. agric. Sci. 54: 310-317.

1949 Aspects of antagonisms between micro-organisms in soil. $\mathrm{Pl}$. Soil 1: 271-276.

1957 The effect of various crop rotations on the incidence of take-all (Ophiobolus graminis Sacc.) in wheat. Sci. Bull. Dep. Agric. Un. S. Afr., no. $379 ; 12$ pp.

1943 Studies on the microbiology of recontaminated sterilized soil in relation to its infestation with Ophiobolus graminis Sacc. Can. J. Res., C, $21: 343-350$.

1966 Soil mycology. In: Res. Rep. Plant sciences and crop husbandry division, An Foras Talúntais 1965: 110.

1967 Studies on wheat rhizosphere soil fungi. Ir. J. agric. Res. 6: 9-14.

1965 Ecology of plant pathogens in soil. II. Influence of glucose, cellulose, and inorganic nitrogen amendments on development of bean root rot. Phytopathology 55: 69-72.

1931 Cycles of growth in cotton root rot at Greenville, Tex. Circ. U.S. Dep. Agric., no. 173; 17 pp.

1957 Effect of crop, crop residues, temperature, and moisture on soil fungi. Phytopathology 47: 559-564.

1959 Occurrence and transfer of a biological factor in soil that suppresses potato scab. Phytopathology 49: 648-652.

1967 Nature of rhizosphere fungal flora of certain plants. Pl. Soil 27: 162-166.

1963 The influence of continuous crop rotation, monocrops and fertilizers on the composition of soil microflora. (In Russian) Izv. timiryazev. sel'-khoz. Akad. 6: 85-92. 
OGILVIE, L. and

I. G. ThORPE

OhNesorge, M.

OKAFOR, N.

PaDwick, G. W.

Paharia, K. D.

PARK, D.

PARK, D.

Parkinson, D.,

G. S. TAYLOR and

R. PEarson

Pearson, E. S. and

H. O. Hartley

Plessis, S. J. DU and

J. H. NORTJÉ

Ponchet, J. and

M. COPPENET

Ponchet, J. and

M. COPPENET

Ponomareva, G. YA.

REBER, $H$.

Reber, $\mathrm{H}$.

ReINMUTH, E. and

D. SeIDEL

Robinson, R. K. and

R. L. LuCAS

Robinson, R. K. and

R. L. LuCAS

Round, F. J.

O'Rourke, C.
1962

1966

1966

1935

1955-6

\section{6}

1967

1963

1943-6 Tables of the probability integral of the studentized range. Biometrika 33: 89-99.

1952 Susceptibility of wheat and rye varieties and of grass species to Ophiobolus graminis Sacc. Sci. Bull. Dep. Agric. Un. S. Afr., no. 328; 19 pp.

1957 Le problème du piétin échaudage des céréales dans les sols bretons. Phytiat. Phytopharm. 6: 157-164.

1962 Influence de divers facteurs culturaux sur le développement du piétin-échaudage, Linocarpon cariceti B. et Br. Annls Épiphyt. 13: 285-291.

1965 Effect of the fungus, Trichoderma lignonum Harz., on the development of winter wheat root-rots in the foothils zone of the Stavropol region. (Engl. summ.). Trudȳ vses. nauchnoissled. Inst. Zashch. Rast. 24: 182-186.

1967a Vergleichende Untersuchungen zur Toxizität und Selektivität von Entseuchungsmitteln für Bodenmikroorganismen. Z. PflKrankh. PflPath. PflSchutz 74: 414-426.

1967b Untersuchungen tuber die Wiederbesiedlung eines chemisch entseuchten Bodens. Z. PflKrankh. PftPath. PflSchutz 74: 427-438.

1966 Die Bedeutung des antiphytopathogenen Potentials im Rahmen der Bodenhygiene. NachrBl. dt. PfISchutzdienst, Berl. 20: 3-7.

1963 The use of isotopically labelled mycelium to investigate the host range and rate of spread of Ophiobolus graminis. New Phytol. 62: 50-52.

1967 Observations on the infection of Zea mays by Ophiobolus graminis. Pl. Path. 16: 75-77.

1967. Intensive winter cereals at Rosemaund. Agriculture, Lond. 74: 141-145.

1967 Survey of diseases of grasses and clover. In: Res. Rep. Plant sciences and crop husbandry division, An Foras Taluntais 1966: 79-81. 


\author{
SAMUEL, G. and \\ S. D. GarretT \\ SANFORD, G. B. and \\ W. C. BroAdfoOt \\ ScHMIDT, $H$. \\ SCHREVEN, D. A. VAN \\ SChRoTh, M. N. and \\ D. C. HILdeBRAND \\ SEMENIUX, G. and \\ A. W. HeNRY \\ Siegle, H. \\ SIMS, H. J. \\ SKIPSNA, J. \\ Slagg, C. M. and \\ H. Ferlows \\ Slope, D. B.
}

SLOPE, D. B.

SMrTH, L. R, and

L. J. AsHworTH

Sprague, R. and

D. B. LAWRENCE

Stumbo, C. R.,

P. L. GAINEY and

F. E. Clark

TAYLOR, A. C.

TuRner, E. M.

TYNER, L. E.

TYNER, L. E. and

W. C. Broadfoot

VAarTaJa, $O$. and

V. P. AGNLHOTRI
1933 Ascospore discharge in Ophiobolus graminis, and its probable relation to the development of whiteheads in wheat. Phyto. pathology 23: 721-728.

1931 Studies of the effects of other soil-inhabiting micro-organisms on the virulence of Ophiobolus graminis Sacc. Scient, Agric. 11: 512-528.

1962 Antagonistische Beziehungen zwischen Actinomyceten und Ophiobolus graminis Sacc. und deren Bedeutung für die Schutzwirkung. Thesis, Giessen; 63 pp.

1962 De microbiologische rijping der gronden in de IJsselmeerpolders. Van Zee Ld 32: 34-70.

1964 Influence of plant exudates on root-infecting fungi. $A, R e v$. Phytopath. 2: 101-132.

1960 Relative decline of Ophiobolus graminis, Helminthosporium sativum and Fusarium culmorum in the soil. Can. J. Pl. Scl. 40: $288-294$.

1961 Über Mischinfektionen mit Ophiobolus graminis und Didymella exitialis. Phytopath. Z, 42: 305-348.

1958 Deadheads in wheat. Their relationship to crop rotation in Mallee Research Station trials. J. Agric. Vict. Dep. Agric. 56: 282-290.

1963 Study on root rot of wheat (Ophiobolus graminis Sacc.) and its control in winter wheat crops in the western areas of the Iatvian S.S.R. Review in: Rev, appl. Mycol. 42: 10-11.

1947 Effects of certain soil fungi and their byproducts on Ophiobolus graminis. $J$. agric. Res. 75: 279-293.

1965 Control of take-all with particular reference to cultural methods. Lecture to a meeting of the Br. mycol. Soc. (unpublished).

1967 Disease problems of intensive cereal growing. Ann. appl. Biol. 59: 317-319.

1965 A comparison of the modes of action of soil amendments and pentachloronitrobenzene against Rhizoctonia solani. Phytopathology 55: 1144-1146.

1959 The fungi on deglaciated Alaskan terrain of known age. (Part I). Res. Stud. Wash. St. Univ. 27: 110-128.

1942 Microbiological and nutritional factors in the take-all disease of wheat. J. agric. Res. 64: 653-665.

1966 Wheat crop surveys in southern New South Wales. 3. The incidence of take-all. Aust. J. exp. Agric. Anim. Husb. 6: 242-245.

1940 Ophiobolus graminis Sacc. var. Avenae var. N., as the cause of take all or whiteheads of oats in Wales. Trans. Br. mycol. Soc. 24: 269-281.

1940 The effect of crop debris on the pathogenicity of cereal rootrotting fungi. Can. J. Res., C, 18: 289-306.

1943 Field tests of the differential reaction of wheat varieties to foot rot. Scient. Agric. 24: 153-163.

1967 Inhibition of Pythium and Thanatephorus (Rhizoctonia) by leachates from a nursery soil. Phytopath. Z. 60: 63-72. 
VIENNOT-BOURGIN, G. $\quad 196$

Vos, N. M. DE

WALKER, A. G.

WALKER, A. G.

WARD, E. W. B. and

A. W. HENRY

WASTIE, R. L.

WATT, J. J. VAN DER

WeinhoLd, A. R.,

J. W. OsWALD,

T. BOWMAN,

J. Bishop and

D. WRIGHT

WELTE, E. and

G. TrolldenIER

Welvaert, $\mathbf{W}$.

WEST, P. M. and

A. G. LOCHHEAD

WINTER, A. G.

WINTER, A. G.

WINTER, A. G.

WINTER, A. G.

WITKAMP, $M$.
1964 Interactions entre les champignons parasites telluriques et les autres organismes composants de la rhizosphère. Annls Inst. Pasteur, Paris, Suppl. 3: 21-62.

1966 Optreden van voetziekten en schade in 1965. Landbouw en Plantenziekten, (1): 2-5.

1941 The colonization of buried wheat straw by soil fungi, with special reference to Fusarium culmorum. Ann. appl. Biol. 28: 333-350.

1967 Intensive cereal growing - Disease control. Agriculture, Lond. 74: 171-175.

1961 Comparative response of two saprophytic and two plant parasitic soil fungi to temperature, hydrogen-ion concentration, and nutritional factors. Can. J. Bot. 39: 65-79.

1961 Factors affecting competitive saprophytic colonization of the agar plate by various root-infecting fungi. Trans. Br. mycol. Soc. 44: 145-159.

1965 Survival of Ophiobolus graminis Sacc. in soils of the winterrainfall region of the Cape. Scient. Bull. Dep. agric. tech. Serv. Un. S. Afr., no. 374; 49 pp.

1964 Influence of green manures and crop rotation on common scab of potato. Am. Potato J. 41: 265-273.

1963 Influence de la microflore du sol sur la nocivité d'Ophiobolus graminis Sacc. chez le blé. Annis Inst. Pasteur, Paris 105: 409-416.

1962 Bijdrage tot de studie van de bestrijding van fytopathogene bodemschimmels door grondontsmetting. Meded. LandbHoogesch. OpzoekStns Gent 27: 1631-1789.

1940 The nutritional requirements of soil bacteria - A basis for determining the bacterial equilibrium of soils. Soil Sci. 50: 409-420.

1940 Untersuchungen über den Einfluss biotischer Faktoren auf die Infektion des Weizens durch Ophiobolus graminis. Z. PflKrankh. PflPath. PflSchutz 50: 113-134.

1944 Der Einfluss partieller Sterilisation des Bodens auf die Entwicklung der Laufhyphen von Ophiobolus graminis. Phytopath. Z. 14: 204-302.

1947 Eine Methode zur quantitativen Bestimmung des Wachstums parasitischer oder saprophytischer Pilze im natürlichen Boden. In: Festschrift zur Feier des achtzigsten Geburtstages von Otto Appel. Biologische Zentralanstalt für Land- und Forstwirtschaft, Berlin-Dahlem: 12-15.

1950-1 Untersuchungen über die Ökologie und den Massenwechsel bodenbewohnender mikroskopischer Pilze. I. Die Bedeutung organischer Nährstoffe für die Entwicklung von Ophiobolus graminis in der Rhizosphäre und im freien Boden. Arch. Mikrobiol. 15: 42-71.

1960 Seasonal fluctuations of the fungusflora in mull and mor of an oak forest. Thesis, Wageningen; $51 \mathrm{pp}$. 
WooD, R. K. S. and M. TVErT

WRIGHT, J. M.

WrIGHT, J. M.

ZoGG, H.

ZOGG, $\mathbf{H}$.

ZoGa, $H$.

ZoGG, H.
1955 Control of plant diseases by use of antagonistic organisms. Bot. Rev. 21: 441-492.

1954 The production of antibiotics in soil. I. Production of gliotoxin by Trichoderma viride. Ann. appl. Biol. 41: 280-289.

1956 The production of antibiotics in soil. III. Production of gliotoxin in wheatstraw buried in soil. Ann. appl. Biol. 44: $461-466$.

1950 Über Mischinfektionen bei Fusskrankheiten des Getreides. Schweiz. Z, allg. Path. Bakt. 13: 574-579.

1951 Studien über die Pathogenităt von Erregergemischen bei Getreidefusskrankheiten. Phytopath. Z. 18: 1-54.

1959 Studien über die biologische Bodenentseuchung. II. Beeinflussung der Pathogenität von Ophiobolus graminis Sacc. durch die Mikrofloren verschiedener Böden mit verschiedenen Fruchtfolgen. Phytopath. Z. 34: 432-444.

1963 Studien uiber die biologische Bodenentseuchung. IV. Eliminierung von Ophiobolus graminis Sacc. im Boden unter Anwesenheit verschiedenartiger monokotyler und dikotyler Futterpflanzen. Phytopath. Z. 48: 272-286. 